\title{
Chiqui: etnohistoria de una creencia andina en el noroeste argentino
}

Chiqui : ethno-histoire d'une croyance andine du nord-ouest de l'Argentine Chiqui: Ethnohistory of An Andean Belief of the Northwest of Argentine

\section{Margarita E. Gentile}

\section{(2) OpenEdition}

\section{Journals}

\section{Edición electrónica}

URL: http://journals.openedition.org/bifea/7314

DOI: $10.4000 /$ bifea.7314

ISSN: 2076-5827

Editor

Institut Français d'Études Andines

Edición impresa

Fecha de publicación: 1 abril 2001

Paginación: 27-102

ISSN: 0303-7495

\section{Referencia electrónica}

Margarita E. Gentile, « Chiqui: etnohistoria de una creencia andina en el noroeste argentino », Bulletin de l'Institut français d'études andines [En línea], 30 (1) | 2001, Publicado el 08 abril 2000, consultado el 07 diciembre 2020. URL : http://journals.openedition.org/bifea/7314 ; DOI : https://doi.org/10.4000/ bifea.7314

\section{(c) $(1)$}

Les contenus du Bulletin de l'Institut français d'études andines sont mis à disposition selon les termes de la licence Creative Commons Attribution - Pas d'Utilisation Commerciale - Pas de Modification 4.0 International. 


\title{
CHIQUI: ETNOHISTORIA DE UNA CREENCIA ANDINA EN EL NOROESTE ARGENTINO
}

\author{
Margarita E.GENTILE*
}

\section{Resumen}

Chiqui era la suerte adversa; la creencia y las ceremonias relacionadas con su propiciación se documentaron en el noroeste argentino a mediados del siglo XIX y a principios del siglo XX. En este ensayo se muestran la variedad de situaciones peligrosas, desgraciadas, chiqui; las formas de congraciar la suerte adversa; sus representaciones; la dispersión de la creencia a lo largo y ancho de diversos paisajes y su honda raigambre andina, presumiblemente relacionada con eventos climáticos tipo El Niño.

Palabras claves: Noroeste argentino, etnohistoria, capacocha, apodos, vulcanismo, loros, maíz, toponimia.

\section{CHIQUI : ETHNO-HISTOIRE D'UNE CROYANCE ANDINE DU NORD-OUEST DE L'ARGENTINE}

\section{Résumé}

Chiqui, c'est la malchance ; la documentation sur cette croyance et les cérémonies liées à sa propiciation se trouvent dans le nord-ouest argentin au milieu du XIXème siècle et au début du XX. Dans cet article nous voulons montrer la variété des situations qui comportent du danger, de la malchance, chiqui ; les façons d'attirer la malchance ; ses représentations ; l'étude de la croyance dans certains endroits et son enracinement profond dans la tradition andine, probablement lié aux événements climatiques El Niño.

Mots clés : Nord-ouest argentin, ethno-histoire, capacocha, surnom, volcanisme, perroquets, maïs, toponymie.

\section{CHIQUI: ETHNOHISTORY OF AN ANDEAN BELIEF OF THE NORTHWEST OF ARGENTINE}

\section{Abstract}

Chiqui was the bad luck; the belief and the ceremonies related to its propitiation were recorded in the Argentine northwestern region by the mid $19^{\text {th }}$ Century and at the beginning of the $20^{\text {th }}$ Century. This essay shows the different dangerous and unlucky situations, chiqui; the ways to obtain the benefits of the bad luck; its representations, the spreading of this belief

*Antropóloga UNMSM. CONICET; Museo de La Plata. Casilla de Correo 3568, C 1000 WBJ Buenos Aires, República Argentina.margagentile@hotmail.com; margagentile@uol.com.ar 
throughout different landscapes and its Andean deeprootedness, presumably related to weather phenomena such as "El Niño".

Key words: Northwest Argentine, ethnohistory, capacocha, nicknames, volcanoes, parrots, maíz, toponymy.

\section{EL RELATO DEL INDIO PERALTA, CIRCA 1880}

Entre los años 1883 y 1885, Samuel Lafone Quevedo publicó varias cartas en el diario La Nación de Buenos Aires, con historias y costumbres de la provincia de Catamarca basadas en documentos coloniales copiados por él mismo o un empleado suyo en el archivo provincial y escribanías locales. También recogió narraciones de sus peones, a quienes interrogaba a través de un intérprete, cada vez que recorría sus campos y minas (Lafone Quevedo, 1888; Cáceres Freyre, 1962).

En una de esas cartas dio noticia acerca de la "Fiesta o juego del Chiqui", el cual transcurría así:

"Cuenta el Indio Peralta nacido en el ya abandonado Pueblo del Pantano, que para celebrar la fiesta del Chiqui hacian reunion de hombres y mujeres, que se juntaban bajo de un algarrobo con varias tinajas llenas de aloja (1); en anticipacion de la tal funcion, dos dias antes salian los hombres al campo á correr liebres, huanacos, pumas y otras aves (2) (menos suris ó avestruces, que respetaban) (3) y con las cabezas de los animales que cazaban daban vueltas al rededor del Arbol (el tacu ó algarroba) entonando el canto o vidala de los Indios y chupando aloja á mas y mejor. Por la tarde organizaban carreras de á pié hombres con hombres y mujeres con mujeres, que se colocaban á distancia como de dos cuadras del arbol mencionado y á una señal dada emprendían la carrera hácia este y el primero que llegaba obtenia el premio asignado, el cual consistía en huahuas (muñecos) de masa y biscochos que estaban colgados en el árbol.

Esta curiosa reliquia del gentilismo fué suprimida por el Cura Maubecin (4) mas ó menos por los años 1859 , así que solo los muy viejos se dan cuenta de su existencia. Segun se me ha asegurado, la fiesta tenía por objeto conjurar la mala suerte en tiempo de seca ú otra calamidad." (Lafone Quevedo, 1888: 249-250) (Fig. 1).

(1) Aloja: bebida alcohólica hecha, en general, con vainas de algarroba blanca molidas y fermentadas (Cáceres Freyre, 1961: 32; nota MG).

(2) Los animales silvestres en general (Cáceres Freyre, 1961: 42; nota MG).

(3) En 1582, los indios que vivían alrededor de la ciudad de Santiago del Estero criaban avestruces mansos en las casas (Torre Revello, 1941, I: 80). Sobre el tema de usar avestruces en el siglo XX para rodear ganado, ver Forgione, 1997. En la provincia de Buenos Aires, la tropilla de J. Perkins, quien quedara inválido luego de un accidente, era arreada por avestruces (H.A. Pérez Campos, comunicación personal; nota MG).

(4) Muy probablemente este sacerdote fue pariente de Vicente Maubecin, gobernador de la provincia de Catamarca en esos años (Cutolo, 1968-1985; nota MG). 


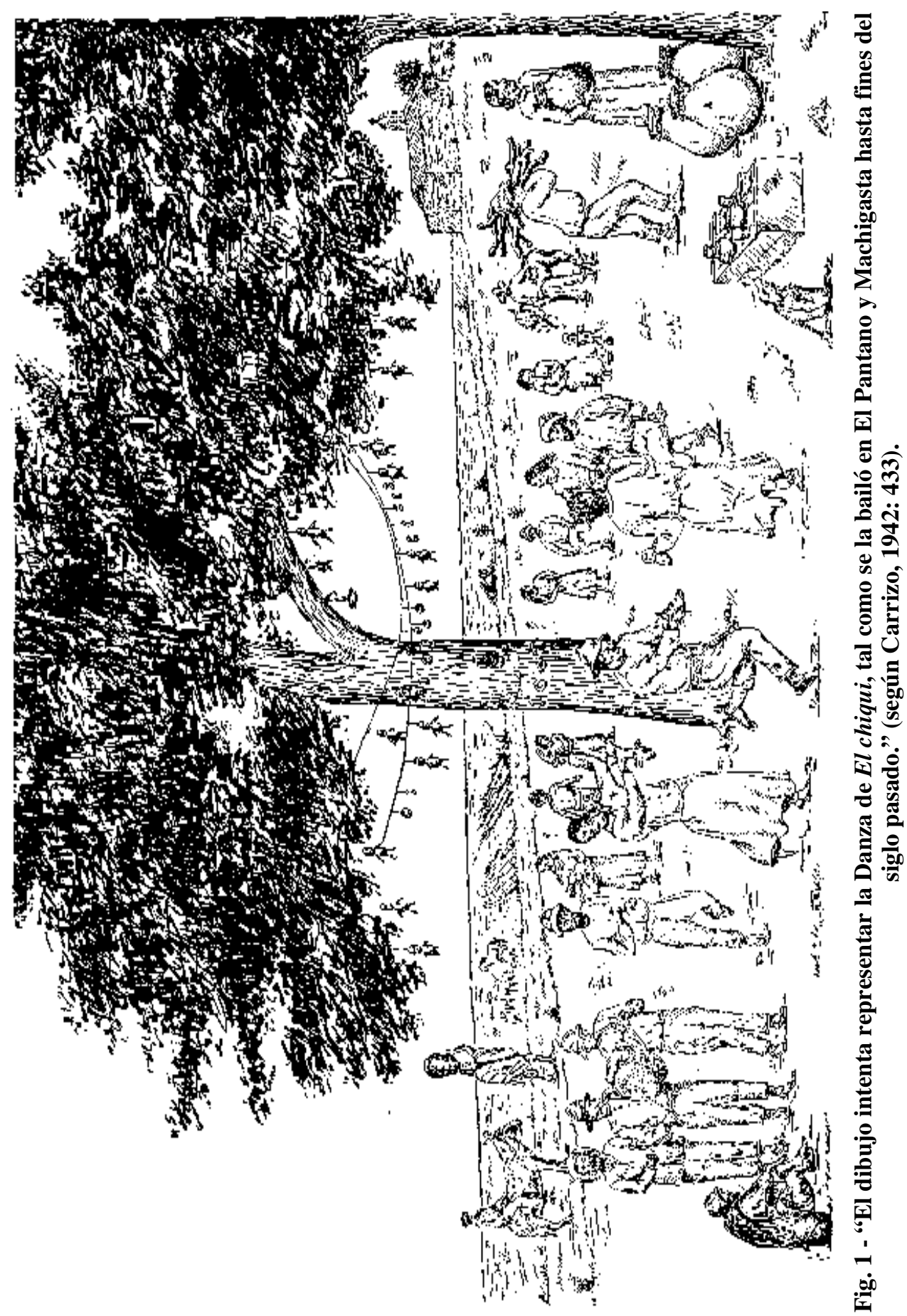




\section{HISTORIA DEL TEMA}

Esta fiesta parece que era una costumbre en el sector árido y montañoso de las provincias de La Rioja y Catamarca; los datos reunidos hasta ahora señalan los pueblos de San Blas de los Sauces, Pituil, Pueblo del Pantano y Pilciao (según Lafone); Machigasta, Pituil y Aminga (según Quiroga); y Antinaco, Arauco y Lorohuasi (según la Encuesta de 1921), todos ellos ubicados en pequeños oasis (Fig. 2 y 3 ).

En 1886 Lafone consiguió que el cura de San Blas de los Sauces (pueblo del Valle Vicioso, llamado así por su feracidad), le copiara la letra del "canto o vidala de los indios", y la agregó a la recopilación de sus cartas en un apéndice con una traducción propia que amplió luego en su "Tesoro de catamarqueñismos..." (Lafone, 1888: 378-380; 1898: 103).

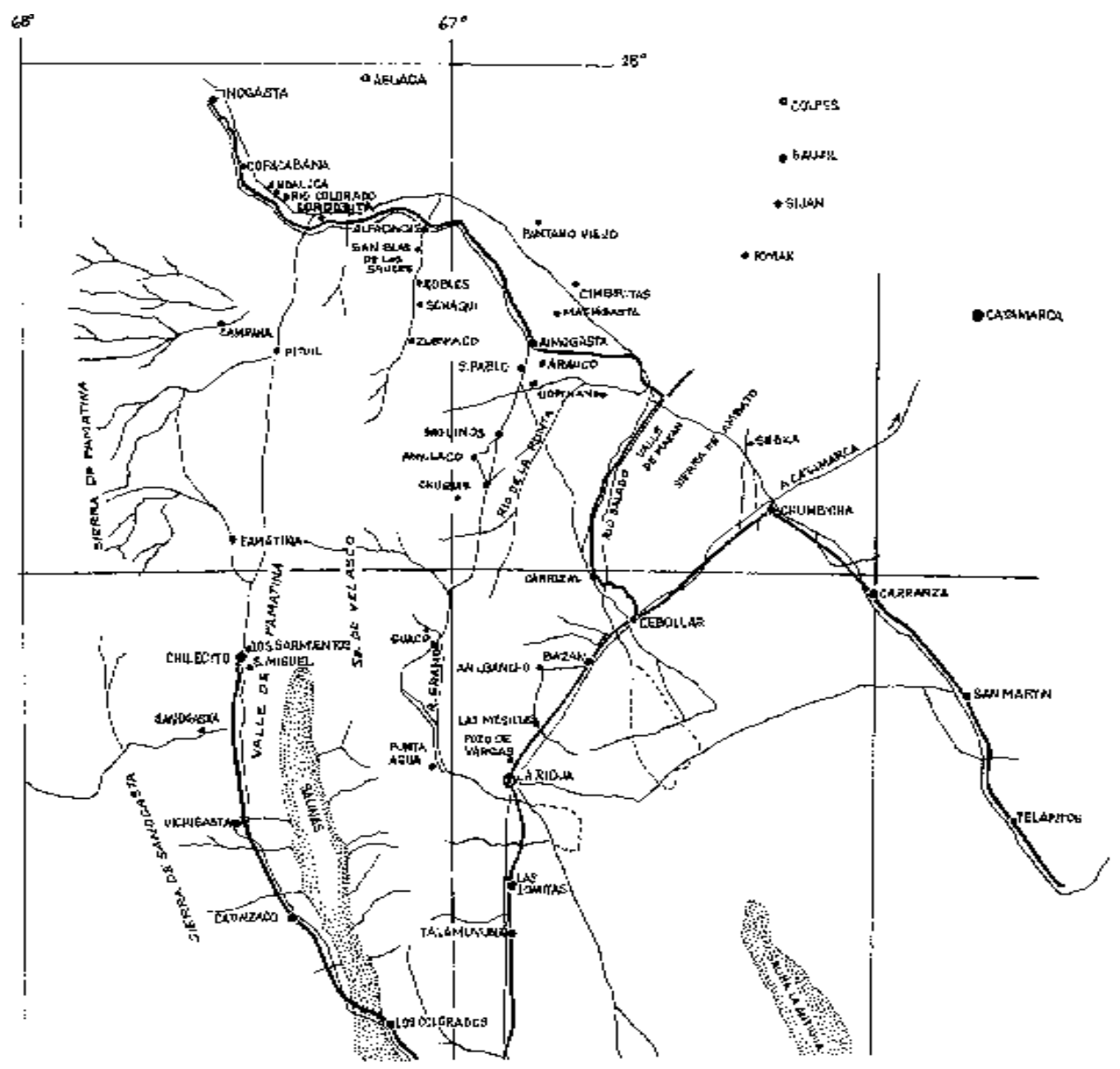

Fig. 2 - Sector de las provincias de Catamarca y La Rioja con los sitios relacionados con la fiesta de $E l$ Chiqui, basado en un mapa de Carrizo, 1942. Dibujo de Susana Albarello. 


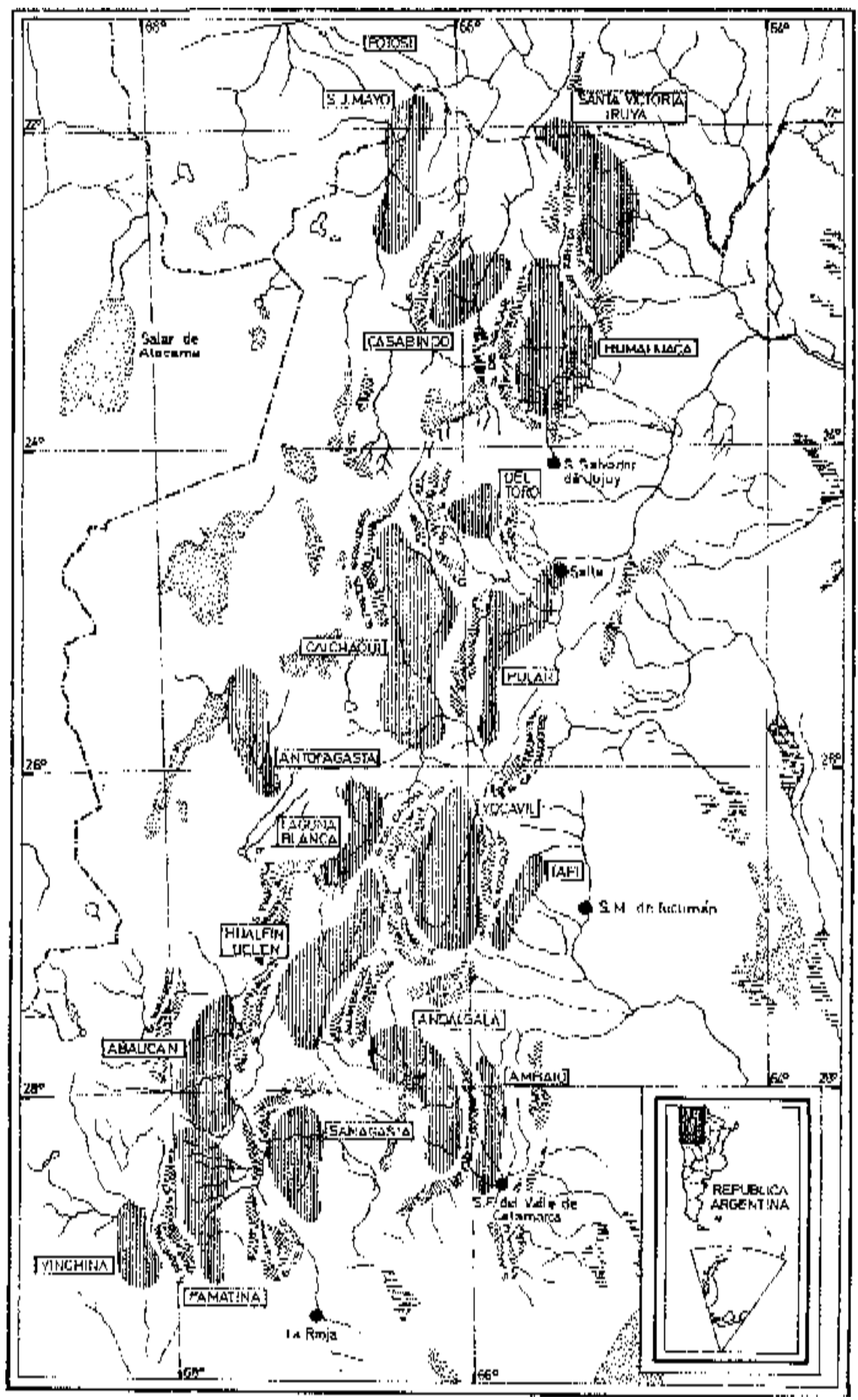

Fig. 3 - El noroeste argentino, con indicación de las principales regiones arqueológicas (según Raffino, 1991: figura 1; Raffino et al., 1997: 31). 
En cuanto a El Chiqui en sí, respaldándose en un tramo de la crónica de Fernando de Montesinos quien definía chiqui como la adversa fortuna, allí mismo relacionó el dato con la fiesta y la vidala porque, según Peralta, esa había sido la finalidad de la fiesta (Lafone, 1888: 377).

Llegados a este punto hay que notar que cuando Lafone publicó su carta sobre la "fiesta ojuego del chiqui", su atención no estaba puesta en ese tema, sino en tratar de definir quienes habían sido las divinidades andinas relacionadas con la meteorología (5), especialmente el rol del suri en las creencias indígenas. El tema de la ausencia de esta cabeza entre las que se llevaban al dar vueltas alrededor del árbol, era su principal argumento para afirmar que se trataba de un animal sagrado relacionado con la lluvia.

También los muñecos de pan que se daban como premio a quien ganaba la carrera, lo llevó a largas consideraciones acerca del relato del marqués de Nadaillac y su viaje hacia los cazadores de cabezas de Borneo, buscando allí comportamientos similares para explicar sus datos riojanos. Recién el texto de Montesinos lo trajo de vuelta a la región andina, dando lugar a un apéndice en la reedición de sus cartas.

Aprovechando estas publicaciones, el abogado Adán Quiroga, también interesado en el folklore, identificó a El Chiqui con ciertos personajes dibujados en el cuerpo de las urnas (6) que le vendían quienes escarbaban con esa finalidad en los cementerios prehispánicos del valle de Yocavil (Santa María, provincia de Catamarca).

Quiroga se basó en esos diseños para afirmar que los restos hallados en el interior de las urnas habían sido ofrendas a $E l$ Chiqui, quien era, según él, una divinidad antropomorfa cuya fiesta era un remedo de otra prehispánica que se realizaba para pedirle que cesara la sequía, ofreciéndole a cambio sacrificios humanos (Quiroga, 1897: 550 y siguientes) (Fig. 4).

Juan B. Ambrosetti, por su parte, definió psicológicamente a El Chiqui explicando que:

“... los calchaquíes hicieron intervenir en todo esto [es decir, achacaron la causa de la adversidad que perseguía a cualquier cosa que emprendieran] a la fatalidad sobrenatural representada por un numen a quien había que conjurar: el Chiquí o Vatí [sic]. La tendencia del hombre a crear sus dioses según su propio retrato, hizo que el Chiquí tuviera los caracteres morales de los calchaquíes y, por esto, lo encontramos vengativo, sanguinario, feroz como ellos, y al que sólo aplacaban conjurándolo con holocaustos sangrientos que le ofrecían con más o menos abundancia. Como esto no bastase, y el Chiquí, a pesar de todo, continuara inexorable, nació entre ellos la idea, o quizá les fue importada, de propiciarse genios tutelares que tuvieran suficiente poder para conjurarlo, y de aquí surgieron

(5) Sus preocupaciones se concretarían en el "Ensayo mitológico - El culto de Tonapa - Los himnos sagrados de los reyes del Cuzco según el yamqui Pachacuti” (1892), donde trató de demostrar que, al contrario de la opinión de E. B.Tylor, los salvajes también podían tener religión.

(6) A estas vasijas de alfarería se las llamó "urnas" por comparación con las urnas cinerarias europeas, porque quienes las hallaban decían que contenían huesos humanos. 
prácticas sangrientas, sacrificios de niños, quienes enterrados en preciosas urnas cerca de sus viviendas, velaban por la felicidad general, combatiendo el numen adverso." (Ambrosetti, 1967[1917]: 118-119)

Acorde con el romanticismo del siglo XIX, este autor hizo hincapié en las pautas artísticas greco-latinas según las cuales los dioses poseían aspecto y sentimientos similares a los de los hombres y, sin más, las extendió al área andina prehispánica.

Además, esta explicación puesta en el contexto de otros trabajos suyos enseña cómo buscaba explicar el hallazgo de restos de niños dentro de las urnas de Yocavil, y cómo los relacionó con sacrificios humanos por la importancia que este tipo de ofrendas había tenido en otras culturas, según ya se estaba sabiendo.

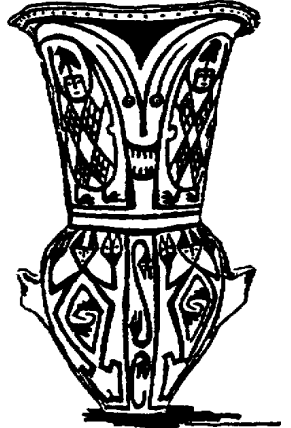

A

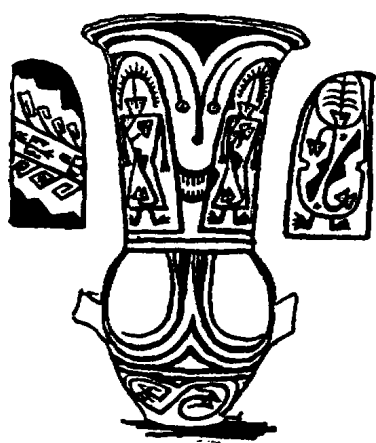

B

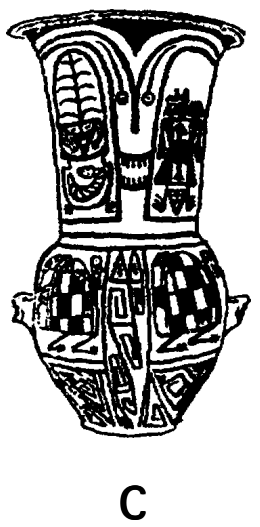

Fig. 4 - A) Urna estilo santamariano, procedente de Andalguala con representaciones de El Chiqui (según Quiroga, 1897: figura 5); B) Urna estilo santamariano, procedente de Andalguala que representaría la transformación de El Chiqui en avestruz, acompañado de signos solares y el algarrobo que brota de su cabeza (según Quiroga, 1897: figura 4); C) Urna estilo santamariano, procedente de Andalguala; arriba, a la derecha estaría representado El Chiqui con una cabeza humana sobre el hombro y el suri dibujado en su ropa (según Quiroga, 1897: figura 3). 


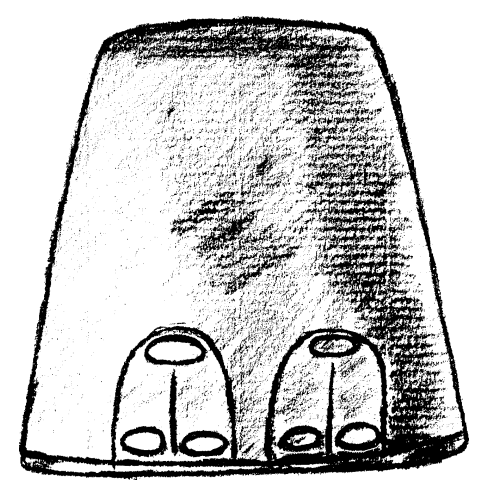

Fig. 5 - "Campana de metal fundida con rostros antropomorfos en relieve. Museo de La Plata $\mathrm{N}^{\circ}$ 5770. Alto: $31,7 \mathrm{~cm}$. Procedencia: Rincón Perdido, depto. Santa María, provincia de Catamarca. Cultura: Santa María, por aproximación tipológica." (dibujo de MG según González, 1977: figura 303).

También decía que las campanas

“... y quizás algunos de los discos [de bronce], sobre todo los que llevan serpientes, deben de haber pertenecido al culto del Chiqui ... [y] llegaríamos á la conclusión de que todos los objetos de este metal historiados con cabezas humanas ó símbolos de serpientes, sapos ó suris, deben haber servido para el culto del Chiqui ó de la lluvia, mientras que los que tienen atributos femeninos ó vejetales se referirían á la Pacha Mama. Deidades ambas de la mitología calchaquí, la primera más antigua y originaria de la tierra [es decir, del NOA] y la segunda más moderna, un desdoblamiento quizás de la otra, adquirida ó importada por las invasiones en otros ó de otros pueblos." (Ambrosetti, 1899: 154-156) (Fig. 5 y 6).

$\mathrm{Al}$ igual que Lafone y Quiroga, Ambrosetti buscó las respuestas a sus preguntas acerca de El Chiqui en datos etnográficos o materiales arqueológicos que eran comunes fuera del área donde se celebraba la fiesta.

Esta discontinuidad no afectaba sus argumentos porque, según Eric Boman, los habitantes prehispánicos de las actuales provincias de La Rioja y Catamarca habían pertenecido, todos ellos, a grupos diaguitas, es decir, participaron de una misma cultura (Boman, 1908: 12-32) (7) (Fig. 7).

Este autor, de cuyo conocimiento de las crónicas publicadas hasta aquel momento se podría esperar algo más, se limitó a señalar la existencia de El Chiqui en el noroeste argentino como "una divinidad peruana", y agregó al ñandú en la lista de animales cazados para festejarlo; su exclusión habían tratado de explicarla Lafone y Quiroga siguiendo, cada uno, ciertos razonamientos (Quiroga, 1977[1901]: 119) que Boman contradijo pero sin decir porqué (Boman, 1908: 180).

(7) Otra opinión acerca de los grupos diaguitas del noroeste argentino en Gentile, 1996a. Y sobre la presencia en la región de grupos no diaguitas después de 1665, ver Gentile, 1986. 

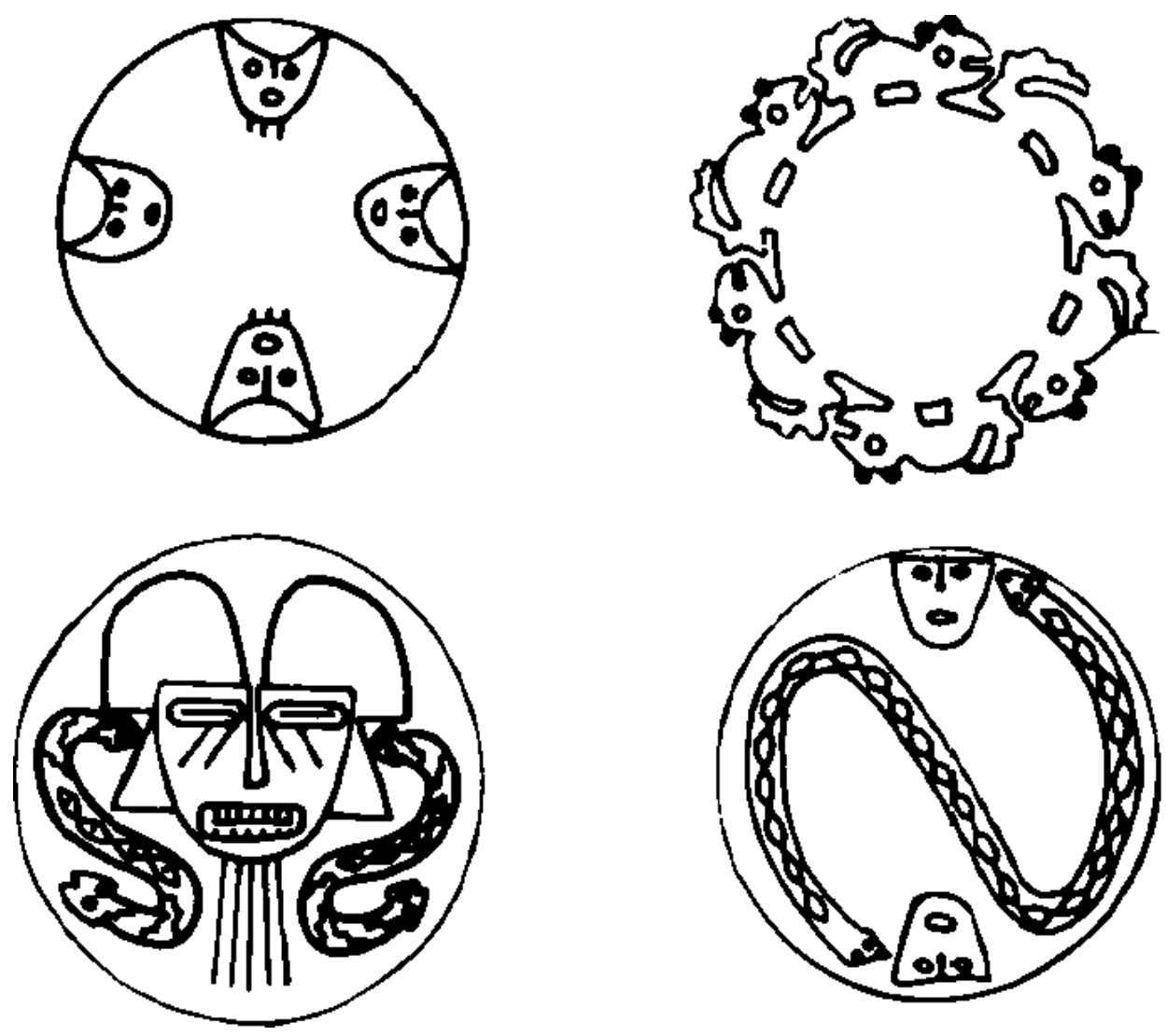

Fig. 6 - Algunos discos de metal procedentes del noroeste argentino, Período Tardío (según González, 1975: chart III).

Excepto Lafone, quien decía que Londres (valle de Quinmivil, Catamarca) había sido una colonia del Cusco (1888: 246), las otras argumentaciones dejaban fuera el tema de la presencia incaica (8), mínimo respaldo que hubiera necesitado la crónica de Montesinos para hacer valer sus dichos aquí.

Para esto también había explicación: acerca de los incas en el NOA, Ambrosetti (tal vez siguiendo al padre Lozano) opinaba que ellos nunca habían gobernado aquí y que los calchaquíes, en cambio, sí habían intentado invadir alguna vez el Cusco trayendo a su regreso algunas costumbres cusqueñas entre las que estaría esta fiesta (Ambrosetti, 1899, Tomo XVIII: 140 y siguientes).

En pocas palabras, las interpretaciones de estos autores acerca de la fiesta de $E l$ Chiqui surgieron de los relatos de otros que habían participado o que la conocían por

(8) La presencia incaica era notable en algunos edificios (Payogasta y Batungasta, entre otros) y en nombres quechuas documentados en el siglo XVI antes de la llegada de los jesuitas (Calchaquí, Collagasta, Maquixacta). 


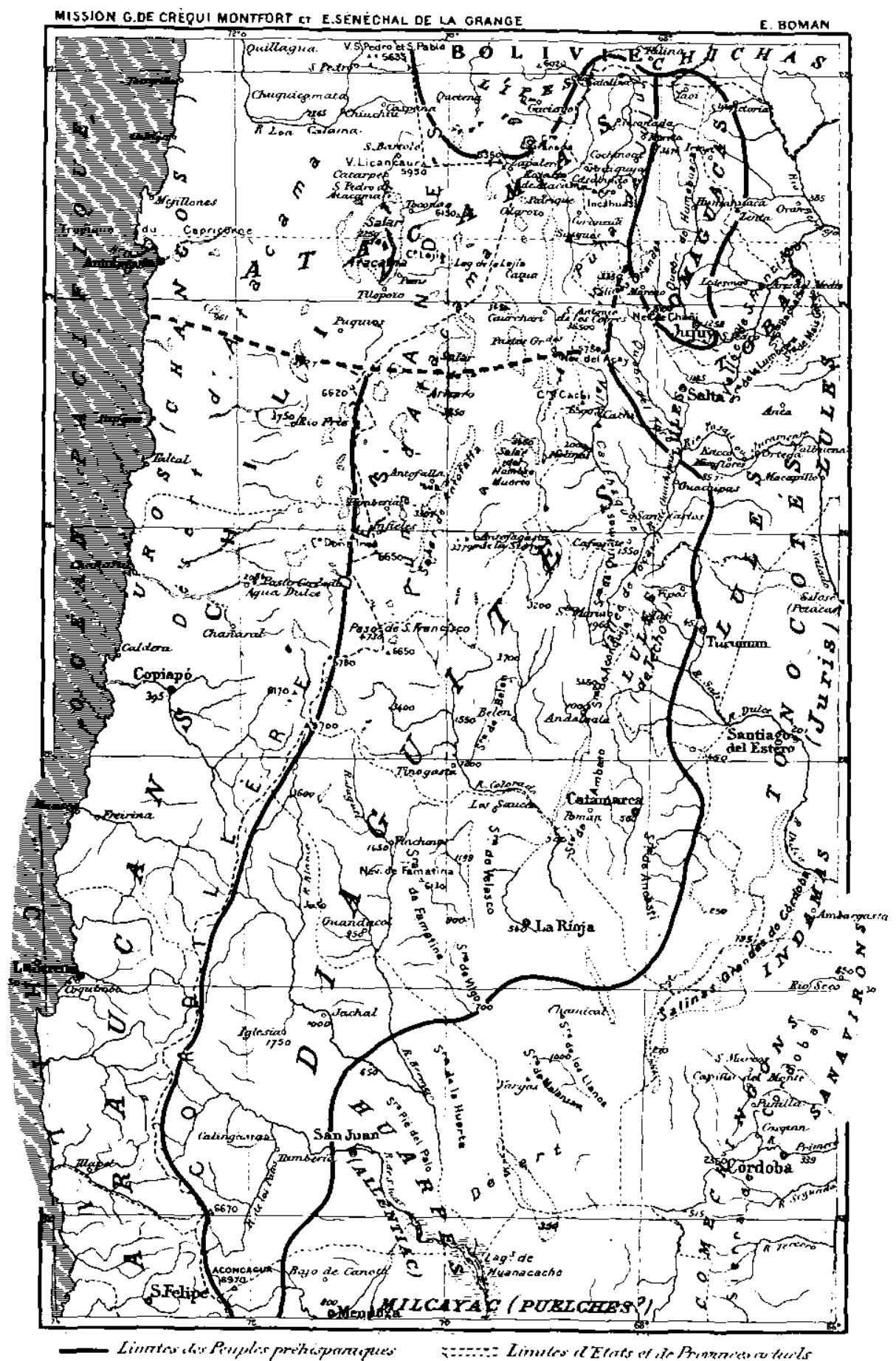

Fig. 7 - El área de los diaguitas, según Boman, 1908. 
haber oido hablar de ella; luego, Lafone encontró una explicación en el texto de Montesinos, en tanto que Quiroga hallaba en las urnas santamarianas una figura antropomorfa plausible, y Ambrosetti relacionaba un supuesto modo de ser y sentir de los calchaquíes prehispánicos con el de su, también, supuesto dios.

Quiroga comentaba que los campesinos se negaban a hablar acerca de El Chiqui y de la fiesta (1897: 550). Finalmente, como punto extremo en las interpretaciones, en una recopilación de creencias se decía que "la fiesta chiqui" (sic) se realizaba en honor del algarrobo, que era el árbol en el que se había ahorcado Judas (Granada, 1959 [1896]: 150).

Más allá de todo esto, en la Encuesta al Magisterio realizada en 1921 ubicamos cuatro versiones de la "fiesta o juego del Chiqui": la primera parecía el relato de una persona oriunda de Antinaco (La Rioja), que regresaba de tanto en tanto a su pueblo; la segunda versión correspondía a alguien que conocía la lengua quechua y tradujo el "canto del Chiqui" incluido en las "Instrucciones..." dentro del rubro "Canciones populares", diferente a como lo hiciera Lafone; la tercera era de alguien que vivía en una población cercana y decía haber participado en la fiesta en los mismos términos que lo relatara el indio Peralta, que era el ejemplo citado en las “Instrucciones...", seguramente leído por el maestro a su entrevistado; en la última versión que hallamos, la entrevistada afirmó que en la zona, Lorohuasi (límite entre La Rioja y Catamarca), otras personas conocían también esa creencia, y se refirió brevemente al momento de la carrera entre mujeres llevando una cabeza de liebre (9).

Juan A. Carrizo pasó en 1938 por Aimogasta cuando preparaba su cancionero de La Rioja; de allí fue al cercano pueblito de Machigasta y vio el algarrobo donde “... los paisanos ... festejaban su chiqui, hasta casi fines del siglo pasado ... en los tres días de Carnaval: Domingo, Lunes y Martes.” (Carrizo, 1942: 432).

Según le contó la hija de Santos Cativa (quien le dictara al padre Vásquez, en 1886, el canto del chiqui),

“... el baile se hacía así: Un hombre tomaba en sus manos cabezas secas o frescas de guanacos, vizcachas, quirquinchos, esto es, de los animales silvestres (de las aves, como ellos dicen a sus animales de caza) que comían. Como notara que ella no mencionaba los suris le pregunté si ponían también cabezas de avestruces y me dijo que sí, que también. No hacía cuestión si ponían o no, no le dió trascendencia a mi sugestión, quizás en sus tiempos, ya el avestruz no tenía el carácter de sagrado que le atribuía el indio [Peralta] mentor de don Samuel Lafone.

(9) La Encuesta no contiene cuestionario sino “Instrucciones ...” en las que, a continuación de una clasificación del material a recopilarse, estaba el desglose de cada tema acompañado con ejemplos extraídos de las obras de Lafone Quevedo, Ambrosetti y otros autores. En el rubro "Fantasmas, espíritus, duendes" figuraban los chiquis ( sic); en "Juegos populares" estaba "el chiqui" a continuación de los naipes, la taba y las bochas. Allí mismo se indicaba que el juego podía acompañarse con cantos y se copió el texto de Lafone de 1888. En cuanto al canto, se lo repitió textualmente en la sección "Canciones populares", pero sin traducir, es decir, los autores de las "Instrucciones..." obviaron la edición de 1898 donde Lafone intentó traducir la vidala o canto del Chiqui, y recomendaban hacerlo (Ramos \& Córdoba, 1921). 
Con estas cabezas en la mano el hombre se ponía contra el tronco del árbol y comenzaba la danza, hombres y mujeres daban vueltas al árbol al compás de la música en tanto el que estaba en el centro movía las cabezas como mostrándolas. Cuando se había dado una o dos vueltas la concurrencia se paraba y cantaba el canto del Chiqui. Mi informante no se recordaba los versos pero sí se recordaba bien que estaban hechos en cuzco [quechua] y que trataban de los servicios que hacían los animales; daban lana, carne y que alegraban los campos.

Otra señora de Aimogasta, que también vivió en tiempo del chiqui, me decía que la concurrencia imitaba el galope del guanaco, o las gambeteadas del suri y me hizo presente que el que dirigía la fiesta imitaba el grito y alguna costumbre de los animales. Me confirmó la noticia de que los cantares del chiqui estaban hechos en quichua pero que también los había en español. Recordaba la señora haber oído este diálogo entre la guanaca y su cría al disparar por las lomas: ¡Achari mamita / ¡mamita! ¡vienen! / ¡perros traen! / ¡No hijita, / son flores de cardón!

Pobrecita —-me decía mi informante—, la guanaquita le advertía a la madre la presencia de un cazador, pero la vieja ... ¡no es tal, le decía, son flores de cardón, hijita!. Achari, es voz quichua y significa "así es, así sera".

En el relato que hizo a don Samuel el indio Peralta, el ochenta y tantos, se nota el carácter sagrado de la ceremonia del chiqui. Se hacía para conjurar algún daño, quizás peste del ganado, o enfermedad de las gentes. En el relato de la Cativa de 1938, desaparece el aspecto sagrado y se ofrece como uno de los números de divertimientos de Carnaval, subsiste la formalidad, no así la intención tradicional con que cincuenta años atrás, en vida del indio Peralta, se celebraba el chiqui." (Carrizo, 1942: 432-434).

Mucho después encontramos referencias a El Chiqui en recopilaciones temáticas. Juan Z. Agüero Vera le dedicó un capítulo de su libro sobre las divinidades diaguitas (1972[s. f.]) en el cual, al tiempo que repetía los datos de Lafone con elocuencia y largueza, citaba a Carlos Quiroga, el hermano de Adán, quien en un libro titulado "Cerro Nativo" decía que El Chiqui era

“ ... como un pájaro maléfico, que cruza los campos desvastándolos, al que es necesario ahuyentar enseñándole signos acuosos, figuras de suris o cruces meteorológicas." (Quiroga, (s.f.): 130).

Estos signos acuosos y las cruces meteorológicas remiten a los diseños de algunas piezas americanas para las cuales se contaba con datos etnográficos que las relacionaban con ceremonias para pedir lluvia, datos que Adán Quiroga había trasladado a sus interpretaciones de la alfarería santamariana (Quiroga, 1977[1901]) (10). Con relación al suri ya vimos que quedaba fuera de la fiesta y en cuanto a la etimología que daba Agüero Vera de la voz chiqui, repitió a Lafone (11).

(10) Sobre los trabajos de Quiroga, ver varias correcciones a los mismos en Bruch, 1911.

(11) "La propia palabra Chiqui ofrece una etimología muy lógica y sugerente: chi o ti es, cosa parada, enhiesta; y qui, partícula dual de ambigüedad, importa estado de desgracia.” (Lafone, 1888: 255 
En "Fiestas y ceremonias tradicionales" se incluyó un capítulo titulado "La fiesta del chiqui", donde se hablaba al principio del chuiqui y se nombraban los trabajos más conocidos, repitiendo la etimología de Lafone. Resumiendo, los autores decían que

"La palabra chiqui (sic) se aplica conjuntamente a la celebración, a la cabeza del animal inmolado y a una canción, especie de vidala que se entonaba durante la fiesta." (Dragoski \& Páez, 1972: 100).

Retomaron la interpretación de Quiroga, el relato de Ambrosetti y cerraron el texto con los dichos de Quiroga, luego de efectuar un recorrido por espacios y tiempos poco definidos.

En cuanto al "Diccionario Folklórico Argentino", la entrada "Chiqui" se incluye tomando de manera resumida la información de Quiroga (Coluccio, 1981: 191). En otro trabajo, Coluccio lo relacionó directamente con el diablo (Coluccio \& Coluccio, 2000: $18,55,69)$.

Desde los estudios de la arqueología, el sentido de la fiesta de El Chiqui fue retomado por Alberto R. González en su libro sobre las placas metálicas surandinas (1992: 183 y siguientes). Su explicación se centraba en la cacería y en las cabezas de animales, porque estaban, a su criterio, relacionadas con el uso de dichas placas en ceremonias de fertilidad. Alberto R. González siguió fielmente a Quiroga y Ambrosetti en los datos y las conclusiones, a pesar de su observación acerca del origen de los datos del primero (González, 1992: 185, nota 4) y afirmaba que "Existió en el Noroeste Argentino una posible perduración folklórica del ritual de la cabeza cercenada, transformada en cabezas de animales." (González, 1992: 185), sin tomar en cuenta que, por ejemplo, en Nasca y Moche hay dibujadas en la alfarería y halladas en las excavaciones cabezas humanas y de animales, es decir, evidencias de que una ceremonia no reemplazó a la otra, sino que una perduró y otra no.

Hasta donde sabemos, luego de Lafone, ninguna publicación sobre El Chiqui aportó más datos sobre la creencia, ni de su ceremonia, quedando el relato del indio Peralta como el texto básico y el de Carrizo como referencia tardía manifestada a través de un discurso previsible.

\section{INTERÉS DEL TEMA Y SU ABORDAJE}

Interesa a los estudios de historia y folklore, entre otros, todo lo relacionado con el origen, continuidades y cambios de las creencias sin perder de vista su contexto social, político, económico, religioso y ambiental.

El tema de El Chiqui nos llamó la atención porque, a pesar de lo dicho antes, había coherencia interna en el relato recopilado por Lafone; además, las negativas de la gente a contarle algo acerca de El Chiqui a Quiroga nos pareció una señal de su vigencia, es

y Agüero Vera, s/f: 137). H.H.Urteaga y C.A.Romero, en las notas a la crónica de Cristóbal de Molina, relacionaron el huarachico con chiqui; así resultaba que este cambio de ropa era "la fiesta o ceremonia para evitar los peligros con el defensivo sagrado de la huaca." (Molina, 1916[1575]: nota 155). Entendemos que esta protección estuvo relacionada con los cantos y palabras que decían las madres de los muchachos mientras tejían dichas huaras. La reedición del diccionario de Gonçalez Holguin fue, indudablemente, una de las mejores herramientas de trabajo con que contamos en el siglo XX. 
decir, chiqui todavía formaba parte de la cosmovisión de los habitantes de esa región. Ni Ambrosetti ni Boman recogieron datos etnográficos en los valles calchaquíes o en la puna y los valles del norte, lo que circunscribía a El Chiqui a un sector comprendido entre las provincias de Catamarca y La Rioja donde, en el siglo XVI, habían vivido los tocpo o "diaguitas del sur" (Gentile, 1996a).

Tomando en cuenta lo mucho que se había avanzado durante el siglo XX en el conocimiento de la historia colonial y lo que ya sabíamos acerca de algunas creencias prehispánicas y coloniales del NOA (Gentile, 1999c), quedaba la impresión de que se podría decir algo más acerca de El Chiqui.

Su presencia en la Encuesta nos llevó a releer a Lafone y al cronista Montesinos, base de su interpretación, un relato donde todo transcurría entre catástrofes climáticas, guerras y celos, en tanto que en los diccionarios coloniales de quechua y aymara abundaban la envidia, el peligro, los agüeros y los cambios de fortuna relacionados con chiqui.

A partir de estos datos, el panorama alrededor de El Chiqui comenzó a hacerse nítido, acotado y, al mismo tiempo, amplio.

En lo que sigue vamos a exponer los resultados de nuestras indagaciones dejando para el final los comentarios sobre la adversa fortuna andina, las ceremonias para congraciarla y sus representaciones.

\section{LA VOZ CHIQUI EN LOS VOCABULARIOS COLONIALES}

Lafone se guió en sus interpretaciones por la crónica de Montesinos; y aunque decía que consultaba el Lexicon del padre Santo Tomás para traducir los textos quechuas, en lo que hizo a El Chiqui no lo tomó en cuenta. Por eso, antes de adentrarnos en las crónicas, buscamos noticias de El Chiqui en los vocabularios coloniales.

Así se evidenció una amplia gama de situaciones con las que podía identificarse la suerte adversa definida por el cronista, relacionadas con el estorbo que produce la envidia, el peligro para sí o para otros que deriva de la ignorancia y la torpeza, los presagios y las mudanzas de la Fortuna. En algunos casos, una acepción es el único nexo entre un grupo de voces y otro (por ejemplo, quencha y tapia). Veamos:

Chiquichini, gui, o tocorichini, gui. Embaraçar.

Chiquicuni, gui, o calchani, gui. Inuidia tener.

Chiquicoc, o chiquicçapa. Inuidioso.

Chiquicay. Inuidia. (Santo Tomás, 1951[1560]: 262)

Chiqui, desdicha, o peligro, o mal aguero.

Chiquiruna, hombre mal hadado.

Chiquimanmi chayani, sucederle algun trabajo.

Chiquini, estoruar o impedir algo.

Chiquicuyhucha, embidia.

Chiquiman raycucuni, ponerse a peligro.

Chiquiman raycuni, poner a otro en peligro. (Anónimo, 1951[1586]: 27)

Desdicha, chiqui.

Desdichado, mana cussioc, mana zamioc.

Desdichado del, ala ymaysoncollam. (Anónimo, 1951[1586]: 134)

Embidia, chiquicuy. 
Embidiar, chiquicuni.

Embidioso, chiquicuc. (Anónimo, 1951[1586]: 138-139)

Fortuna que muda las cosas, raqui acoyraqui, tiuy raquí.

Fortuna buena, cussi.

Fortuna mala, tapia ati. (Anónimo, 1951[1586]: 146)

Guamán Poma decía, refiriéndose a los animales que con su presencia o su canto anunciaban que iba a suceder alguna desgracia, que

"Los dichos abocioneros, agüeros que sustener los yndios antigos de los Yngas y en este tiempo lo tienen desto de atatapya tapyauanmi [La mala fortuna me ha maldecido], acoyraqui [infortunio], tiyoraqui [calamidad]." (Guamán Poma, 1980[1613], I: 255); la traducción del padre Urioste figura entre corchetes.

En el siglo XX, el padre Fortuny registró en el valle Calchaquí "Tapia: yeta" (Fortuny, 1974[1951]: 280).

Chhiqui. El peligro.

Chhiqquimanchayani. Estar en peligro.

Chhiqquipi purini. Andar en peligro.

Chhiqui. La desgracia, o desdicha desuentura, o sucesso malo.

Chhiqquiyoc. El desgraciado, o desuenturado.

Chhiqquiçapa. El desgraciadissimo en todo que nada le sucede bien.

Chhiqquipincani, o purini. Estar en riesgo, o peligro.

Chhiqquiman chayani, o chhiqquim chayahuan. Caer en el peligro.

Chhiqquip muyoy cuscan. Cercado de peligros.

Chhiqquiçapa. El que esta cercado de peligros.

Chhiqquiyoc camallam. Todos andan metidos en muchos peligros.

Chhiqquimuz coy. Vission mala para mal, o desgracia.

Chhiqqui mauzccuytam, o tapiactan o chhiqquictam ricuni. Ver vission mala ensueños.

Cussimuz cuytam, o cussi ricuytam ricuni. Ver vissiones buenas.

Suti chhiqquictam, o tapiactam ricuni. Ver mala vission no en sueños sino despierto.

Suticussictam ricuni. Ver vissiones buenas en sueños como despierto.

Chhiqquik chhiquik runa. Embidioso, o malicioso, o perjudicial que impide bienes y haze daños.

Chhiqquicuy camayoc chhiqquicuc sonco mitta mitta chiqquicuk. Embidioso de costumbre y de mala voluntad.

Chhiqquimanmi yacachayani o cay llayccuni, o chhiqquiman cispaycunicispam purini. Puseme en peligro, o llegue a punto y ocassion de pecado, o daño, o trauajo.

Chhiqquiycuyni, o chiquini. Estoruar o impedir algun bien, o hazer algun daño. Machayhuchan comulgacuyta chhiquissunqui. La borrachera te daña y estorua para comulgar.

Chhiqquiy ccachani. Poner impedimentos, o estoruos a otros, o dañarles, o priuar del bien.

Chhiqquipayani chhquiycuni. Ser ocassion del daño, o peligro de otro, o ponerle en peligro. 
Chhiqquiyccuy hucha. Peccado de imbidia.

Chhiqquiccuni. Auer, o tener imbidia de otro.

Chhiqquiman rayccuccuni. Darse ocasion de caer con ponerse al peligro.

Chhiqquiman raycuni. Poner a otro en peligro.

Chhiquicuy camayoc. Hombre de malas entrañas amigo de hazer daño, o imbidioso. (Gonçalez Holguin, 1952[1608]: 112-113).

Quencharuna. El torpe de manos perdido, no grangero no aprouechado que todo lo pierde y daña.

Qquenchayacuk, oqquencha chanak. El desgraciado aborrido por pobre y para poco. Quenchayacuni. Hazerse assi desgraciado.

Quenchachanani. Venir a ser pobre y aborrido el que no lo era.

Quencha ccari. El amigo, o casado que no le quiere la amiga, o muger, que le ha aburrido.

Quencha huarmi. La muger aburrida del varon.

Quenchani. Aburrir, y dexar el hombre a muger, y los casados repudiarse, o dexarse.

Quenchapayani. Desechar muchas vezes, y huirse del, o della.

Qquenchanacuni. Repudiarse, o aburrirse el vno al otro, y dexarse. (Gonçalez Holguin, 1952[1608]: 302)

Embidiar, o codiciar lo bueno. Munapayapucuni.

Embidia. Chhiqquicuy.

Embidiar lo malo. Chiqquicuni.

Embidiar estoruando el prouecho o dañandolo. Chhiqquipayapuni.

Embidioso. Chhiqquicuyk. (Gonçalez Holguin, 1952[1608]: 498)

Desdicha. Chhiqquicay.

Desdichado en lo que pone mano que no le sucede. Chhiqui runa kencha mana usapu mana ymantapas yachacuchik.

Desdichado. Mana cussiyoc cussinnak.

Desdichado en el juego que nunca gana, mana samiyok, o samin nak (vee dichoso).

Desdichado del, Ala ymay sonccollam ala cuyay cuyaylla, o misero pobre de ti. (Gonçalez Holguin, 1952[1608]: 482)

Fortuna, o infortunio, o caso graue desastrado. Raqui, acoyraqui ttiyuiraqui.

Fortuna, oinfortunio grande tener. Accuyraqui ttiuyraqui manchayani, ottiuyraqui aparihuan.

Fortuna buena, cussi cussillacay, o cussicay y la alegria y paz y quietud.

Fortuna buena, o dicha tener. Cussi cussillam, o cussiyoc llam cani.

Fortuna mala. Chiqui chiquilla cay. Kenchacay.

Fortuna mala, o desdicha tener. Chiqqui chhiqquillamcani Kenchamcani mana cussiyok cani manamyamaypasyachacunchu.

Bien afortunado ser. Cussiyoc, o cussi cussillamcani.

Mal afortunado en ganar. Chhiqqui chhiqui runa o kencha. (Gonçalez Holguin, 1952[1608]: 527)

Ympedir el prouecho, o el bien de alguno. Chhiqquicuni.

Ympedidor del prouecho, o bien. Chhiqquik chhiqquicuk. (Gonçalez Holguin, 1952[1608]: 553) 
Desdicha: Chiqui. (Torres Rubio, 1945[1619]: 132)

Fortuna buena: Cusi.

Fortuna mala: Tapia ati. (Torres Rubio, 1945[1619]: 138)

En el estudio de los textos quechuas realizado por César Itier para acompañar la edición de la crónica de Joan de Santa Cruz Pachacuti, tenemos:

- ch ikiymantam: por ser desventurado (Itier, 1993: 144-145, 196)

- chiquicuna: desventuras (Itier, 1993: 148, 259)

Continuemos con el vocabulario aymara del padre Bertonio:

Chhikhi, Talaco: Desastre, o mal sucesso.

Chhikhiro puritha: Tenerle.

Chhikhini haque: Desastrado.

Chikhikhtara: Muy desastrado.

Chhikhi haque: Vno que persuade a otro lo que no combiene.

Chhikhittatha: Estoruar assi, Dios manca hakhsuhasiri, Humaqnaa chhikhittitta.

Queriéndome boluer a Dios, tu me lo has estoruado.

Chhikhi halantatha. Idem.

Chhikhisitha: Ser malsin vnos con otros, buscar ocasion para malos sucesos.

Chhikhisaatha: Ser causa que algunos no esten bien entre si, que riñan, y se lleuen mal. (Bertonio, 1879[1612]: 81)

Embidia: Hithina, Hitisiña + Tenerla: Hithitha, Hithisita + Tenerla al que vende mas: Chikhisitha: Mpi.

Embidiar. Idem. (Bertonio, 1879[1612]: 204)

Desdichado: Cusiuisa, Quellpouisa, Huatina, Koya, Okho haque.

Desdichado del: Alaa koya haque Cha.

Desdicha: Cusiuisa cancaña.

Desdichados de vosotros los maycos: Alaaa, vel Atakh, vel Ataakoya mayconacacha. (Bertonio, 1879[1612]: 177)

Peligro: Chikhi + Correrle. Chikhiro puritha, Niattatha. + Tener, o correr peligro de muerte: Hacampi hihuampitay pincatha, vel Niattatha, Niattatito.

Peligrar la hazienda, plata, carneros \&cc. Chikhiro puritha \&cc.

Peligroso camino: chikhini thaqui. (Bertonio, 1879[1612]: 357)

En muchos de los vocabularios actuales que consultamos no hay ninguna referencia a chiqui, peligro, envidia ni nada que se les relacione ¿como si no existieran?

\section{1. El relato del padre Fernando de Montesinos (1642)}

Esta crónica se publicó por primera vez en castellano en 1870 y luego en 1882 (Pease, 1995: 451); esta última edición fue la que usó Lafone (1888: 377). Y la frase que le aclaraba el misterio decía “... el chiqui, que asi llamaban a la adversa fortuna [los hechiceros y sacerdotes del inca]".

Pero el relato era complejo: decía que cuando reinaba Titu Yupanqui Pachacuti, el sexto Inca de este nombre y el $62^{\circ}$ rey peruano (12), hubo terremotos y cometas en

(12) La crónica de Montesinos fue dejada de lado en los trabajos de investigación de la historia andina porque su lista de incas no coincidía con otras más lógicas como la de Miguel Cabello Valboa, Pedro Sarmiento de Gamboa, el padre Acosta o el Inca Garcilaso. Dicha lista de incas sería similar a 
el cielo; y mucha gente decía que se iba a destruir el reino y que sus habitantes iban a ser expulsados de él. El Inca consultó entonces a los encargados de ver el futuro en las entrañas de los animales y éstos le dijeron que

“... había muy malos pronósticos y malos sucesos en todo, y que el chiqui, que así llamaban a la adversa fortuna, predominaba en todas las cosas tocantes al rey." (Montesinos, 1957[1642]: 56).

En vista de estos presagios, el inca mandó construir fortalezas, porque tanto de los Andes, como del Collao y de los Llanos, venían hacia el Cusco grandes ejércitos, destruyendo e invadiendo. En uno de los asaltos murió el Inca y fue sepultado secretamente en Tamputocco. Terminada la guerra, los vencidos pidieron permiso para enterrar sus muertos, pero éste les fue negado y la corrupción de los cadáveres generó tal peste que murieron casi todos los soldados de ambos ejércitos.

La peste no llegó a Tamputocco, sitio mágicamente protegido, pero cuando las provincias aliadas se enteraron que el Inca había muerto aprovecharon para rebelarse, entretanto que los de Tamputocco tenían “... disensiones sobre elegir rey...”.

Aseguraba Montesinos que luego de todos estos desastres se perdió el gobierno de los incas y que por más de cuatrocientos años no volvió a resurgir. Mientras, cada provincia eligió a su rey y el Cusco quedó deshabitado, salvo por los ministros del templo que quedaron allí; el gobierno civil pasó a Tamputocco donde estaba el heredero de Titu (Montesinos, 1957[1642]: 57-59).

Luego, cambiando de tema y refiriéndose al "maleficio amatorio", Montesinos decía que si una persona quería relacionarse con otra tenía que llevarle al hechicero alguna prenda personal de la misma para realizar el encantamiento; al final de la ceremonia

“... limpian las preseas que tienen delante diciendo: 'con esto limpio y quito de todos vuestros actos y amores la adversa fortuna', que llaman chiqui. Toman luego todo lo dicho, y con la coca mascada y otras cosas que han ofrecido a la guaca de los amores, y alguna chaquira, lo ponen en una olla nueva, y entiérranla en un lugar secreto y apartado, de ordinario en la junta de dos ríos, a que los indios llaman tincuc." (Montesinos, 1957[1642]: 80)

\section{2. Nombres de personas}

El morfema chiqui estaba incorporado a nombres de personas que por alguna circunstancia estuvieron, a su vez, relacionadas con el peligro y la desgracia. Repasaremos algunos casos.

Uno de los relatos decía que Inga Roca había nombrado sucesor a su hijo Yáguar Guaca (Titu Cusi Gualpa) y que se había aliado con Tócay Capac, ancestral competidor

la de Blas Valera (Escobar Risco, 1951: XIII), cronista del que últimamente se han encontrado papeles y objetos que cuentan otra historia (Laurencich Minelli, 1999; Laurencich Minelli et al., 1998). En todo caso, Giovanni Annello Oliva, amigo de Valera, agregaba al final de su lista de trece incas: “... no dexaré de deçir aquí también como ay otra [lista de incas] no mal fundada, que los Incas Reyes del Perú fueron muchos más en número de los que tengo referidos...” (Anello Oliva, 1998[1631]: 95). 
de los cusqueños; una hija de este curaca, llamada Mama Chiquia, se casó con Yáguar Guaca, mientras que Inga Roca daba otra hija suya por mujer a Tócay Cápac (Sarmiento, 1943[1572]: 133-134).

Otro relato se refería a Topa Inga Yupangui quien había nombrado sucesor a un hijo suyo, bastardo, llamado Cápac Guari, hijo de Chuqui Ocllo (Sarmiento, 1943[1572]: 235) (13).

Estos dos relatos fueron ampliados por la crónica del padre Martín de Murúa, quien decía que la Coya Cusi Chimpu, llamada también Mamamacai, mujer de IncaRoca, había tenido varios hijos: Yáguar Guácar, Apomaita, Vilcaquiri, un tío (sic) llamado Guayllacan-Caua, y una hija "llamada Ipaguaco, y por otro nombre, Mamachiqui, Coya y Señora” (Murúa, 1946[1590]: 93).

Según el mismo autor, Yáguar Guácac se casó con Cucheimpuino y no tuvieron hijos de manera que heredó el reino el hijo que tuvo en otra de sus mujeres; este muchacho se llamaba Vira-cocha Inga (Murúa, 1946[1590]: 67).

El apodo de la coya Ipaguaco era Mamachiqui y esto quedó confirmado más adelante, cuando Murúa contaba que Yahuar Huacac "Fue casado con Ypaguaco Coya, por otro nombre llamada Mamá Chiquia; dejó un hijo llamado Viracocha Ynga ..." (Murúa, 1986[1613]: 71) (Fig. 8).

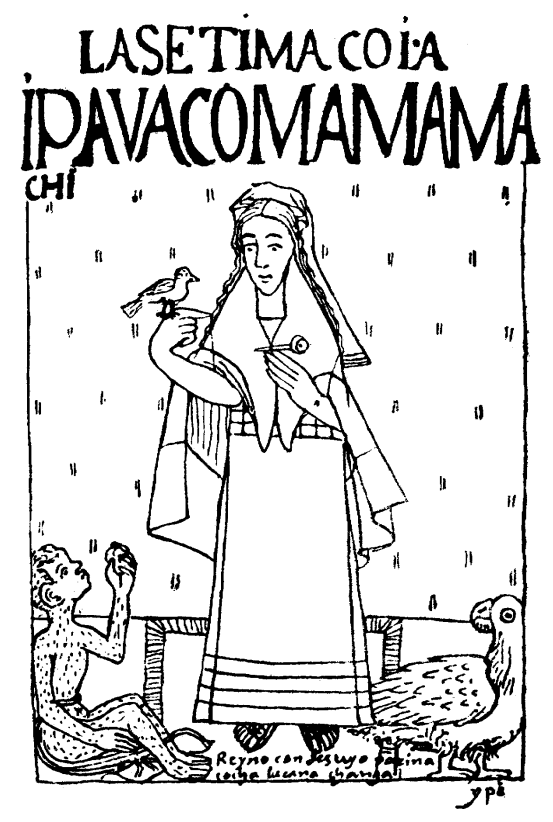

Fig. 8 - La coya Ipaguaco, "Fea, de narises larga y el rrostro largo y del talle flaca y seca, larga.” (según Guamán Poma, 1980[1613]: 110). Por el piso camina un loro.

(13) Parece que las mujeres de Topa Inga Yupangui eran gente decidida. La señora Guayro consiguió que su hijo gobernara cinco pueblos vecinos al lago Titicaca, los llamados aylluscas (Cobo, 1964[1653], II: 86). Y Ramos Gavilán trae noticia de una cacica valiente originaria del mismo ayllo Guayro (1976[1621]: 92). 
Más adelante en el tiempo, otro relato se refería a Tupa Inga Yupangui y decía que éste había muerto muy viejo, a causa de un flechazo. El Inca había nombrado sucesor a su hijo Capac Chuare porque había amado mucho a su madre, llamada Chiqui Ocllo (Murúa, 1986[1613]: 99).

Pero parece que esta decisión, en la explicación del cronista, contradecía la costumbre de que el heredero del Inca debía ser hijo de

“... 'la coya y reina principal, que comúnmente era su hermana ...'. Por eso, cuando ya estaban por coronarlo, '... salieron los hermanos de Mama Ocllo, mujer legítima de Tupa Ynga Yupanqui, de través, visto el agravio y sin razón que se hacía a Huayna Capac, su sobrino, que era el que legítimamente heredaba el reino, diciendo que no había de consentir tal injusticia, y que lo que hasta allí se había con gran puntualidad guardado por todos los Yngas, en cuando a la sucesión en el reino, se había de cumplir ahora, dando el señorío y jurando por rey a su sobrino Huayna Capac, pues era el verdadero señor y sucesor de su padre, Tupa Inga Yupanqui, a quien el reino se le debía de derecho y justicia, pues Capac Huare no era hijo de coya y reina y que así en cuanto a esto no se había de seguir la última voluntad de Tupa Inga Yupanqui. Con estas razones tan evidentes se suspendió la coronación de Capac Huare y los que le seguían entibiaron, y más cuando de nuevo los tíos de Huayna Capac levantaron, o fuese con verdad o mentira, que Chiqui Ocllo era hechicera y que con hechizos y veneno había muerto a Tupa Ynga Yupanqui, porque su hijo Capac Huare entrase en el señorío, y así mataron a la Chiqui Ocllo, y a su hijo Capac Huare le desterraron de común consentimiento a Chinchero, tres leguas del Cuzco, adonde le señalaron los alimentos y servicio de criados y mujeres y chacaras muy abundamentemente para que allí viviese apartado y no pudiese jamás entrar en el Cuzco.'” (Murúa, 1986[1613]: 101-102).

Más adelante, el mismo cronista contaba que Guáscar Inga estaba casado con Chiquillauto, quien por otro nombre se llamaba Mama-varita-cayo (Murúa, 1946 [1590]: 78) (Fig. 9).

Estas mujeres tuvieron un nombre y un apodo: Ipaguaco Coya luego se llamó Mamachiqui o Mama Chiquia y su matrimonio selló una alianza entre enemigos; Chiqui Ocllo (cuyo nombre anterior a la conjura no conocemos), fue asesinada por sus parientes, acusada de haber matado al Inca para que su hijo lo sucediese; y Chiquillauto, llamada Mama-varita-cayo, esposa de Huascar tampoco tuvo ni una vida ni una muerte buenas (Fig. 10 y 11).

En el ámbito del noroeste argentino donde se registró la fiesta de El Chiqui, en el siglo XVII el hijo de uno de los caciques tocpo, nacido en la época de las rebeliones indígenas, era Chiquilpa (Gentile, 1996a: 137); y en 1630, en las ciénagas del río San Juan vivía el cacique Miguel Chiquipay, sucesor en el cargo de uno de los caciques ahorcados durante un alzamiento (Michieli, 2000: 55).

Sus vidas transcurrieron entre el peligro y la desgracia; y chiqui, como parte de sus nombres, tenía la finalidad de señalar esta característica para la Historia. 


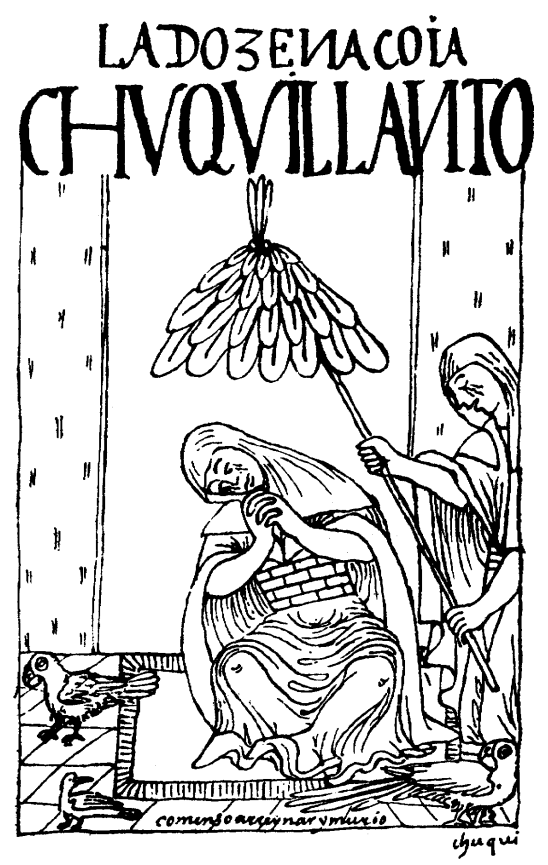

Fig. 9 - La coya Chvqvillanto "comenso a rreynar y murio ... se acauo la uida triste desta señora” (según Guamán Poma, 1980[1613]: 120). Dos loros la acompañan, caminando por el piso de la habitación.

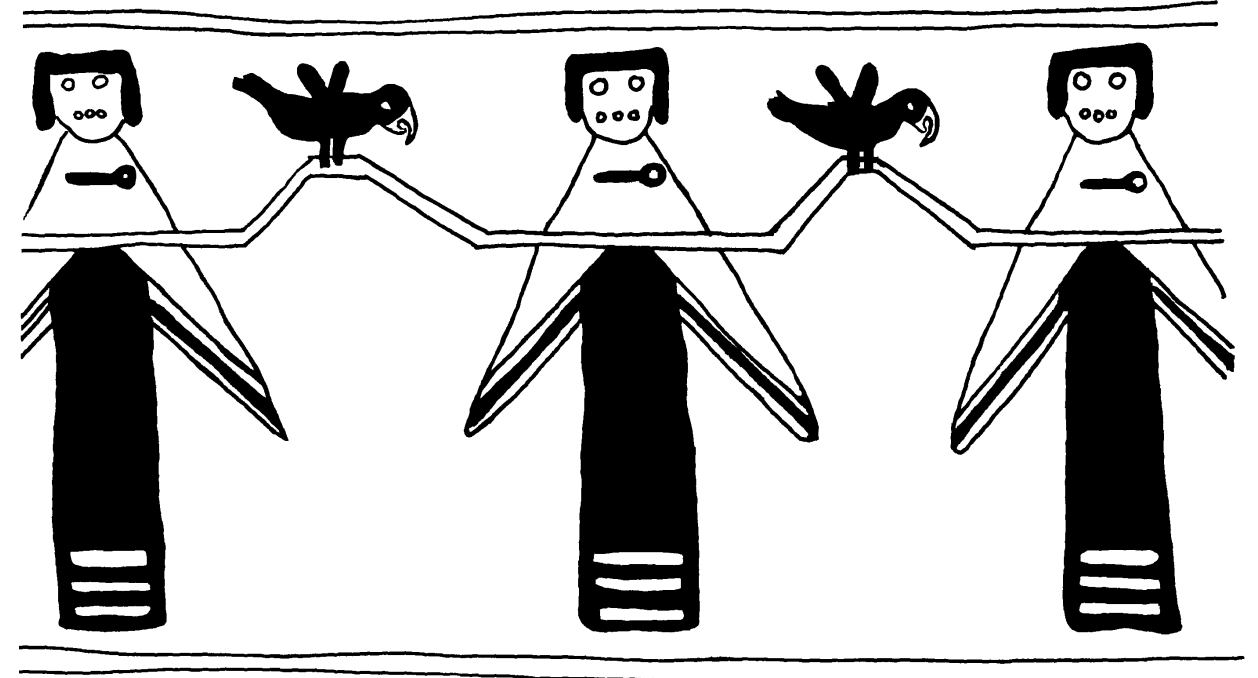

Fig. 10 - Alfarería incaica. "Mujeres avicultoras de talle esbelto sosteniendo loros sobre los dedos.” (Dibujo de Fátima Hatano según Fernández Baca, 1989: figura 328) 


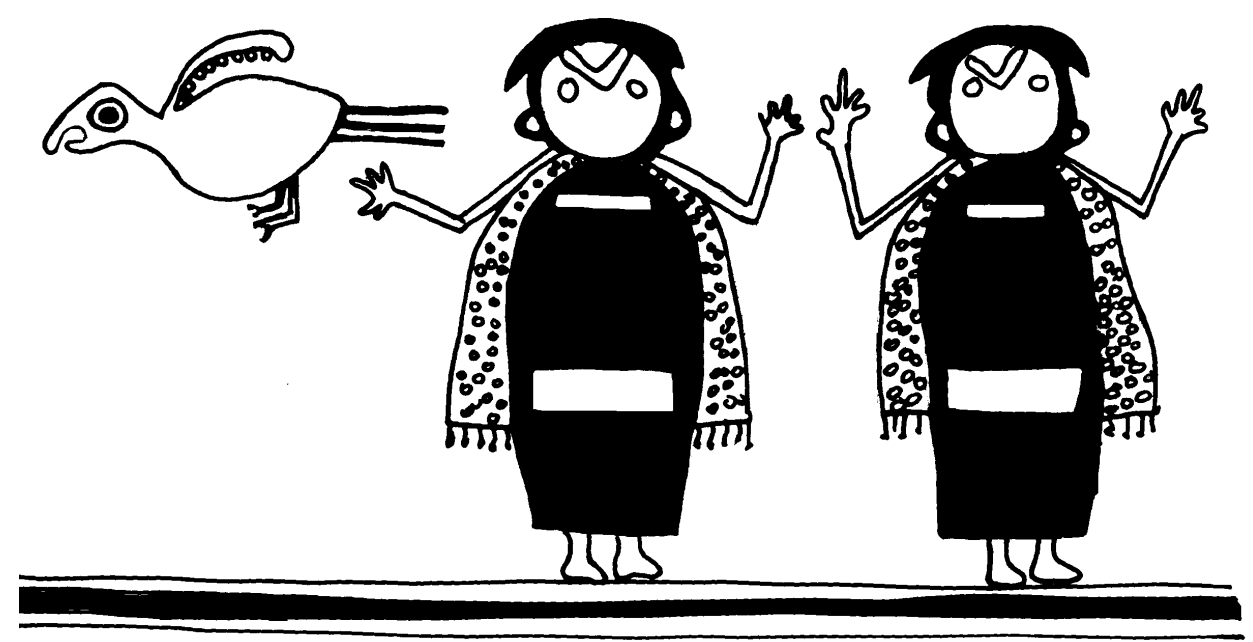

Fig. 11 - Alfarería incaica. "Original representación de avicultoras sin boca ni nariz espantando un loro.” (Dibujo de Fátima Hatano según Fernández Baca, 1989: figura 329)

\section{3. Nombres de lugares}

\section{3. 1. Chiqui, cerca de Challana}

Por la visita realizada a los cocales de Sonqo en 1568 sabemos que los mismos estaban ubicados en las yungas de La Paz y que el tributo en cestos de coca lo reunían en un lugar llamado Chiqui, a unas 2 leguas del pueblo de Challana (14), participando de este trabajo solamente los "yndios mozos y no viejos ni yndias viudas" (Murra, 1991: 134), es decir, solamente trabajaban allí las personas físicamente aptas para soportar el clima de los valles calientes, al que no estaban acostumbrados los serranos porque les provocaba enfermedades graves, especialmente la uta (Leshmaniasis).

\section{3. 2. Chiqui Omate}

Cuando nació Amaro Topa Ynga, hijo de Pachacutec Ynga Yupangui, hubo erupciones volcánicas, terremotos, cometas, arco iris y aparición de animales nunca

(14) Challana significa "lo que sirve para challar", es decir, para hacer ofrendas. ¿Se puede suponer que la coca producida en Sonqo era de uso ceremonial?

(15) El Potina, llamado también Putina o San Francisco, es el actual volcán Misti que se encuentra junto a la ciudad de Arequipa, según Bouysse-Cassagne \& Bouysse (1988: 139). En una lista de volcanes activos consultada por estos autores, (uno de ellos especialista en el tema), no había registro histórico para otros volcanes involucrados en este cataclismo, pero sí había un registro (14381471 d.C) para el Misti (Bouysse-Cassagne \& Bouysse, 1988: 143), que podría considerarse con reservas para ubicar dentro de esas fechas el nacimiento de Amaro Topa Ynga. 


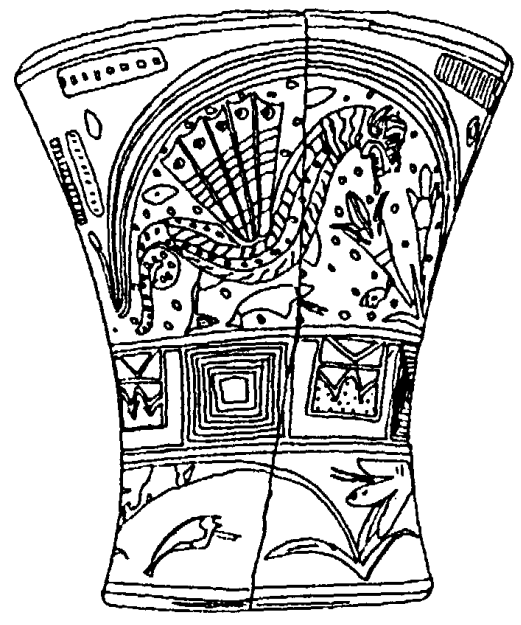

$10-10395$

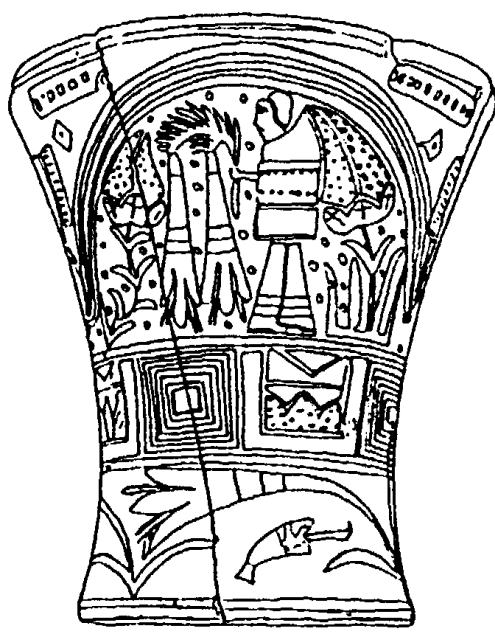

Mo- 10395

Fig. 12 - Kero de madera policromada con escena de animal fantástico a un lado y una ñusta con flores en las manos, en el otro rodeados por el arco iris (según Soldi, 1997: figura MO 10395).

antes vistos; uno de los volcanes activos fue el Potina de Ariquipa (Santa Cruz Pachacuti, 1993[1613]: 223-224), que era el Omate o Huayna Putina (Cobo, 1964 I[1653]: 95-103) (15) (Fig. 12).

Se contaba que este muchacho había preferido dedicarse a la agricultura y a la arquitectura antes que entrar en la contienda por la sucesión en el gobierno del Cusco; que en sus chacras nunca helaba y siempre llovía a tiempo; y que él había enseñado a construir las colcas para guardar las cosechas de maíz y papas; por eso la gente quería adorarlo, cosa que él no permitió, por su modestia (Pachacuti Yamqui, 1993[1613]: 228-230).

Sin embargo, en un pueblo de la cuenca del río Pampas, actual departamento de Apurimac, se usó hasta principios del siglo XX en las ceremonias de la marca y esquila de las llamas, entre otros, un quero de madera cuyos dibujos recordaban algunas de las circunstancias fantásticas que acompañaron el nacimiento de este Inca (Soldi, 1997: figura MO-10395; Gentile, 1998a: 49 y siguientes).

Pero ésta no fue la única erupción memorable en la región; Lozano, basándose en documentos de la época que estaban en la casa de los jesuitas en Córdoba, decía que en 1582 hubo una erupción del volcán de Arequipa (Lozano, 1874-1875 I [1745]: 441).

En febrero del año 1600 los volcanes de Arequipa volvieron a mostrarse activos; uno de ellos fue el Ubina y el otro el Chiqui Homate (Murúa, 1946[1600]: 232; BouysseCassagne \& Bouysse, 1988), al que el padre Cobo, testigo presencial de la erupción, identificó con el Omate o Huayna Putina, junto al río Tambo, actual departamento de Moquegua (Cobo, 1964 I [1653]: 95-103) (Fig. 13).

Los pueblos destruidos fueron “... Chiqui, y Omate, Quinistaca, Tasatachen y Collana, sin que de todos ellos escapase ánima viva.” (Murúa, [1613]1986: 543), u “... Omate, Lloque, Tarata, Colaña, Chec y Quinistaca ...” (Cobo 1964[1653], I: 99). 


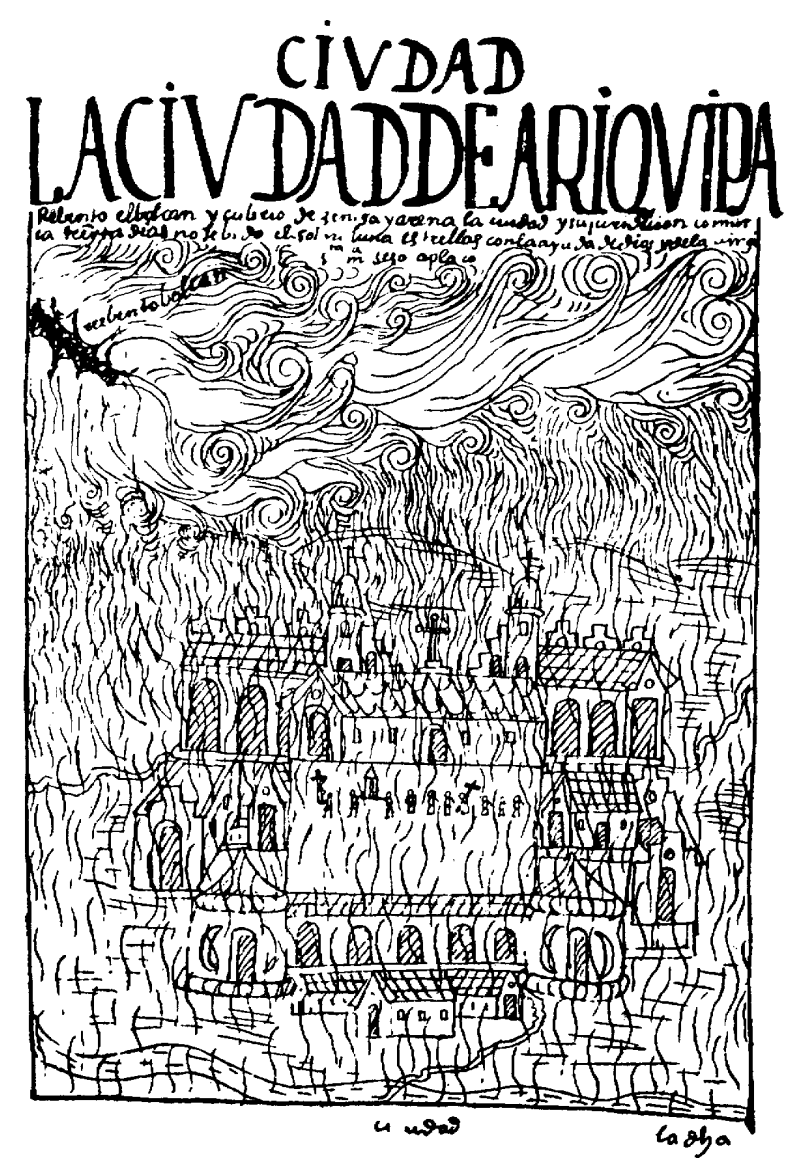

Fig. 13 - La ciudad de Arequipa durante la erupción del año 1600 que la cubrió de ceniza y arena; durante treinta días no se vio ni el sol ni la luna ni las estrellas (según Guamán Poma, 1980[1613]: 972).

Volviendo atrás, luego de la erupción prehispánica, la región arrasada había vuelto a ser habitada; hay algunos listados de 1564 y 1578 donde figuran los pueblos de Ubinas, Omate y Mages, pero entre ellos ninguno era llamado Chiqui (BouysseCassagne \& Bouysse, 1988: 183). Este agregado (Chiqui Omate) se hizo, entonces, luego de la erupción del año 1600. Antes, el volcán se llamaba Huayna Putina, es decir, “el jóven triste” o “el jóven que provoca tristeza” (Gonçalez Holguin, 1952[1608] : 298).

\section{3. 3. Chiquinapampa}

En 1571, durante la información llevada a cabo en el valle de Yucay por orden del virrey Francisco de Toledo, los testigos respondieron de manera similar a la sexta pregunta relacionada con la capacocha, pero algunos que habían participado pudieron agregar detalles al promedio de las declaraciones porque: 
“... vieron y entendieron que en tiempo de Guaynacapac Ynga, por su mandado se sacrificaban niños y niñas a sus Idolos, matándolos, y que para esto les traían de cada provincia a un lugar que se llama ChiquinaPampa y Aurynaucaypata que es en esta ciudad, en la plaza de Santo Domingo, y allí los metían para hacer el dicho sacrificio, y escogían los más hermosos y que fuesen limpios de lunar y otras señales, y a estos apartaban y sacrificaban a los dichos Idolos, y a los demás los dejaban, y que a las madres de los niños y niñas que sacrificaban les daban de comer en las dichas partes donde se hacía el sacrificio, y el dicho Don Martín Nacpa Yupanqui escogía muchas veces las dichas criaturas para el dicho sacrificio, e todos los dichos testigos y cada uno de ellos dijeron que se hacía tres veces cada año y que esto es lo que saben de esta pregunta." (Levillier, 1935-1942, II: 163).

Al sitio de Chiquinapampa parece que también lo nombraba el licenciado Polo en su relación de los ceques del Cusco: en el rumbo Antisuyu había nueve líneas sobre las que se encontraban distribuidas setenta y ocho huacas, el primer ceque de Antisuyu se llamaba Collana, y la primera huaca de él se llamaba Chiquinapampa, que era como

“... un cercado que estaba junto al templo del Sol, en el cual se hacía el sacrificio por la salud universal de los indios." (Polo, 1917[1571]: 16; Cobo, 1964[1653], II: 174-175; Rowe, 1979: 28).

En quechua, la partícula $n a=$ lo que sirve para, añadida al radical de un verbo lo convierte en sustantivo y significa el objeto que sirve para hacer lo que el verbo indica (Guardia Mayorga, 1973: 297). Chiquina sería, entonces, lo que sirve para alejar la desgracia o el peligro. Igual en el quechua de Santiago del Estero (Bravo, 1975: 100).

La explicación del significado del topónimo lo relacionaba con una planicie (pampa) con una pared perimetral (cercado) donde se hacían ofrendas (sacrificio) para alejar las enfermedades (pedir por la salud de los indios), que, de suceder, sería una circunstancia desgraciada, es decir, chiqui.

\section{3. 4. Chiquiligasta}

Francisco de Aguirre, que gobernó en el Tucumán con altibajos entre 1553 y 1566, le informó a Juan de Matienzo que sí era posible abrir a las carretas la ruta que este oidor proponía, uniendo la ciudad de Santiago del Estero con el fuerte Sancti Spiritu construido por Sebastián Gaboto a orillas del río de La Plata (actual Paraná), o con otra parte distinta de la costa de dicho río.

Para comprobarlo, Aguirre salió de Santiago el 12 de mayo de 1566 y fue desde esa ciudad a Manogasta, a cuatro leguas, y de allí a Ayachiquiligasta, a otras tres leguas, y luego a Ayambagasta, a dos leguas más (Matienzo, 1967[1567]: 281-282).

Es muy probable que sus carretas iban bordeando el río Dulce, de manera que Ayachiquiligasta quedaría a unos 35 kilómetros. Sin embargo, por el entorno parece que se encontraba Manogasta, que junto con Soconcho eran las mercedes de tierras que le correspondían en el siglo XVI al cargo del gobernador del Tucumán.

Entonces, ¿el sitio que nos interesa se encontraría más hacia el sur, siempre siguiendo el río Dulce? Esta ruta nos lleva a una región donde aún hoy día el curso 
divagante de los ríos Dulce y Salado entorpece la circulación fuera de las rutas consolidadas, de manera que el cálculo de distancias antiguas es forzosamente aproximado (16).

En dos mapas del siglo XVII, el topónimo Ayachiquiligasta no figura (Furlong, 1936 I: 24 y II: mapas 2 y 3). Sin embargo, hacia el noroeste de Santiago estaba Chequiligasta (años 1632 y 1647), nombre de un lugar que no figuraba en el itinerario de Matienzo, cuando éste hizo la ruta de San Miguel de Tucumán a Santiago del Estero, pese a haber pasado por Tipiro, punto cercano a aquel Chequiligasta (Fig. 14).

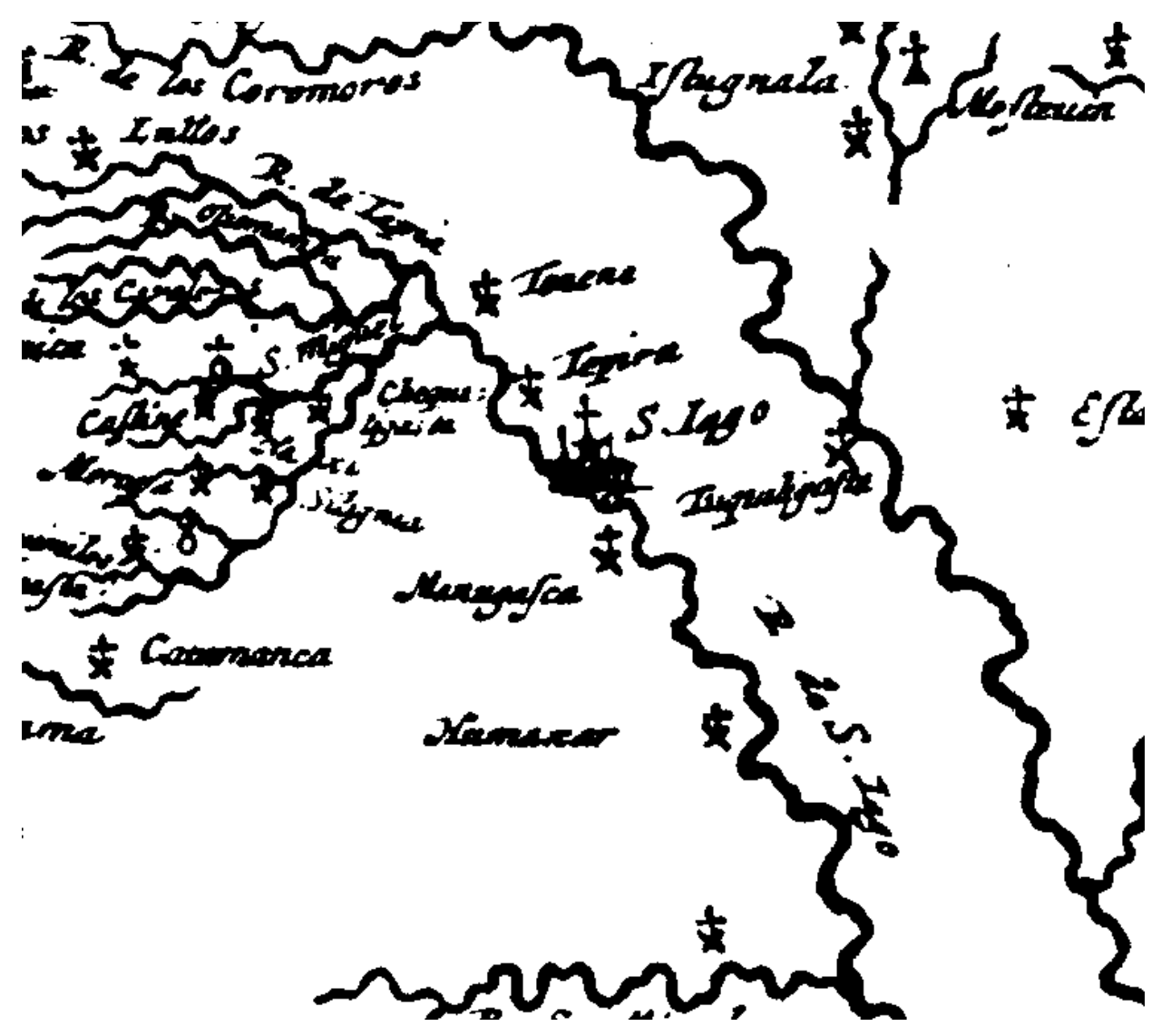

Fig. 14 - La ciudad de Santiago del Estero y su entorno en el "Mapa de las regiones del Paraguay, compuesto por el padre Luis Ernot”, fechado entre 1624 y 1667 (según Furlong, 1936, II: mapa 3). El río de Santiago es el actual río Dulce.

(16) Durante una rebelión, en 1559, los indios se hicieron fuertes en las ciénagas del río Salado donde los españoles no podían llegar a caballo (Levillier, 1920b, II: 26). Sin embargo, el agua había estado canalizada durante el gobierno incaico y los españoles aprovecharon esta circunstancia para fundar Santiago del Estero en la región, pero el mantenimiento de las acequias entre montes de algarrobos y arenales requería una organización del trabajo que ellos estaban lejos de poder liderar. 
El cálculo de la ubicación del sitio nombrado por Matienzo más bien nos pondría en el Tuquiligasta de los mapas del siglo XVII, sobre la costa del río Salado.

Pero si retomamos el topónimo Ayachiquiligasta, podría tratarse de una población (gasta = llacta) muerta (aya) o infortunada (chiqui). Es decir que en 1566, cuando Aguirre intentaba abrir la ruta entre Santiago del Estero y el río de La Plata, ese poblado no estaba habitado, o algo así. Si tomamos en cuenta el divague fluvial según los años con más o menos agua, tanto Ayachiquiligasta como Ayambagasta (17) (la siguiente "dormida" en la ruta de Matienzo) eran propensas a sufrir la formación de ciénagas, que desde todo punto de vista, era una situación desafortunada, es decir un chiqui.

En 1579 había un pueblo de indios llamado “... Chiquiligasta [en] terminos y jurisdicion de Santiago del Estero ...” (Levillier, 1920b, II: 182), pero sin ubicación precisa. Chiquiligasta, es decir, Chiquillacta, ¿sería la población o poblado chiqui?

En 1628 dicha población estaba al oeste de Santiago del Estero, al pie del cerro Aconquija, y era la más poblada de indios de los alrededores de Tucumán (Jaimes Freyre, 1915, I: 159; Larrouy, 1923: 365; Torre Revello, 1941: 338; Gentile, 1998c).

Suponemos, entonces, que la población de indios domésticos de Ayachiquiligasta situada en la ruta entre Santiago del Estero y la fortaleza de Gaboto fue mudada por los españoles a un lugar menos expuesto a los desbordes de los ríos Dulce y Salado, y estando allí ¿aún habría motivo para mantener un topónimo relacionado con un sitio muerto o deshabitado?

Luego de la centenaria guerra de Calchaquí, en 1670 el gobernador Alonso de Mercado y Villacorta le recomendaba a su sucesor Angel de Peredo, que era importante que los grupos de indios rebeldes fuesen ubicados “... hacia la parte de los pueblos domesticos de Chiquiligasta y Yucumanita ..." y que esta decisión debía tomarse al margen de las audiencias de Chuquisaca y Buenos Aires (Torre Revello, 1941, I: 273; Gentile, 1996a).

Entre 1678 y 1692, el pueblo de Chiquiligasta tenía veinte indios tributarios y una iglesia con la imagen de Nuestra Señora de la Candelaria (Larrouy, 1923: 390-392; Torre Revello, 1941, I: 354-355).

En 1688 eran treinta y cuatro los indios de tasa, más tres caciques principales; pero al final del documento figuraba solamente Don Diego, de diez y seis años, como cacique (Lizondo Borda, 1945, V: 36 y siguientes).

Sabemos por un testamento que en 1693 había una imagen de Nuestro Señor de Chiquiligasta en la iglesia de ese pueblo (Lizondo Borda, 1945, V: 185), lo que podría estar indicando que había sucedido una aparición milagrosa de la imagen o algo así, suceso relativamente común en el noroeste argentino, colonial y actual (Gentile, 1999b: capítulo 8).

El padrón de 1711 daba 33 indios de tasa y dos caciques principales (Lizondo Borda, 1949, VI: 157-161; Martin, 1963: 63); y a fines del siglo XIX Chiquiligasta era todavía el nombre de una villa en la provincia de Tucumán, ubicada sobre el río Gastona (Lafone Quevedo, 1898: 104) o río del Conventillo (Coní, 1951[1877-1880] : 77); en el siglo XX se la conocía como Chicligasta.

(17) Un desvío del río Dulce hacia el sudeste, a partir de Manogasta, desagüa en las salinas de Ambargasta. 
Según este repaso, el pueblo siempre tuvo más habitantes que otros cercanos, que eran indios domésticos, es decir, confiables, y que tenía imágenes religiosas importantes. Visto desde otro ángulo, esto no debería llamar la atención porque en la cima del cerro Anconquija, a cuyo pie estaba Chiquiligasta, hubo un santuario incaico (Hyslop \& Schobinger, 1990) cuyos edificios tenían una planta similar a la del templo del Sol en la isla del lago Titicaca; también al pie del Anconquija estuvo el cacicazgo prehispánico de Marapa con una importante población (Gentile, 1998c).

\section{3. 5. Chiquina}

Cuando se fundó la ciudad de Córdoba, en 1573, Chiquina loloba era un algarrobal junto a la aguada de Cocoyanta; en este sitio vivían indios que servían a la ciudad y que en varias oportunidades estuvieron de guerra, protegidos por lo intrincado de los montes (Montes, 1950: 68, 102, 106).

Antes de 1605, Chiquina y Guañagasta eran pueblos de Santiago del Estero cuya encomendera, Isabel Mejía, había sucedido a su esposo, el capitán Pedro de Villarreal (Doucet, 1980: 484).

En 1673, se menciona un pueblo de Santiago del Estero (Ravignani, 1932: 302), de ubicación imprecisa, pero en jurisdicción de la ciudad; las referencias de 1682 nos permitieron ubicarlo en los alrededores de Salavina (Torre Revello, 1941, I: 357), entre los montes de algarrobos, el río Dulce, arroyos salobres y esteros. A fines del siglo XVIII, Salaviña era un pueblo que era parte de la encomienda del alcalde ordinario de Santiago del Estero (ANB EC $1694 \mathrm{~N}^{\circ} 27 \mathrm{f} .277$ v) y en el siglo XIX se pasaba por Salavina para ir a Córdoba (Lafone Quevedo, 1898: 286).

La referencia para el siglo XX es curiosa:

"Chiquina, top. Nombre de un paraje en la antigua Salavina. Lugar donde se encierran a las crias para que no mamen a las madres. Procede del verbo Chíquiy, con esta acepción. Es un arcaismo, hoy en desuso, dentro de nuestro quichua. Ver na." (Bravo, 1975: 41).

No hay entrada para el verbo chíquiy.

El paraje de Salavina es vecino de la zona donde se encontraba la alfarería del estilo Averías, y entre sus piezas más interesantes había una pichca excepcional por su tamaño y diseños que interpretamos como una forma de oráculo relacionado con ciertos fenómenos meteorológicos típicos de la región (Gentile, 1998b; 1999c) (Fig. 15).

Por ahora no tenemos nada que nos permita relacionarlo con Chiquinapampa, excepto su propio nombre (vale aquí lo que dijimos acerca del significado de Chiquinapampa), y la presencia incaica en la región.

\section{3. 6. Chiquiguasi}

En su “Carte des provinces de Catamarca de Tucuman", Martin de Moussy (18601866) señaló un caserío llamado Chiquiguasi sobre la ruta (hoy día en desuso) que unía las ciudades de Catamarca y Córdoba, y cerca de él, yendo hacia el arenal de algarrobales y salinas, un lugar para criar ganado también llamado Chiquiguasi, ubicado justo donde se sumía el agua del río de Paclín formando un bañado. Actualmente, este lugar no es apto 


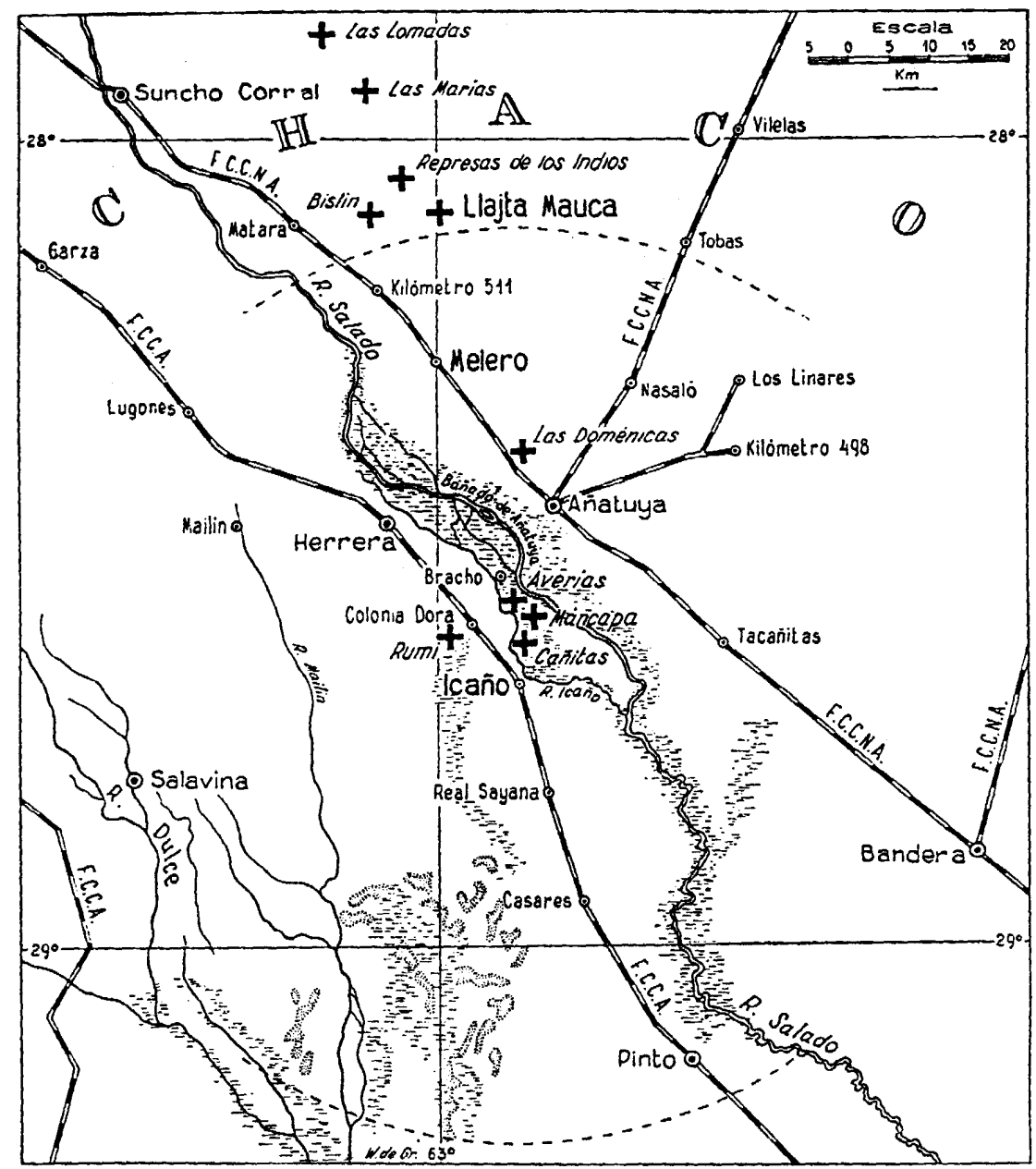

Fig. 15 - Alrededores de Salavina, provincia de Santiago del Estero, con los meandros y esteros del río Salado. Las cruces indican los sitios con alfarería estilo Averías (según Imbelloni, 1940: 84).

para la vivienda humana, y lo llaman Sissihuasi (hormiguero) y cerca se encuentra la salamanca del Portezuelo (Néstor Kriscautzky, comunicación personal) (Fig. 16).

Sobre este interesante topónimo (= casa de El Chiqui, o algo así), no hemos podido hallar, hasta ahora, más referencias; tampoco se conservó en las cartas modernas que consultamos.

En el entorno de este viejo topónimo hay, por lo menos, un abrigo con una pintura rupestre estilo Aguada y una cueva con dos galerías pero sin pinturas, consideradas salamancas hoy día (Néstor Kriscautzky, comunicación personal) (Fig. 36).

También procede del valle de Paclín uno de los “ídolos suplicantes” (González, 1977: figuras 184, 185 y 186; Raffino et al., 1997: lámina 1). Estas piezas de piedra, cuya 


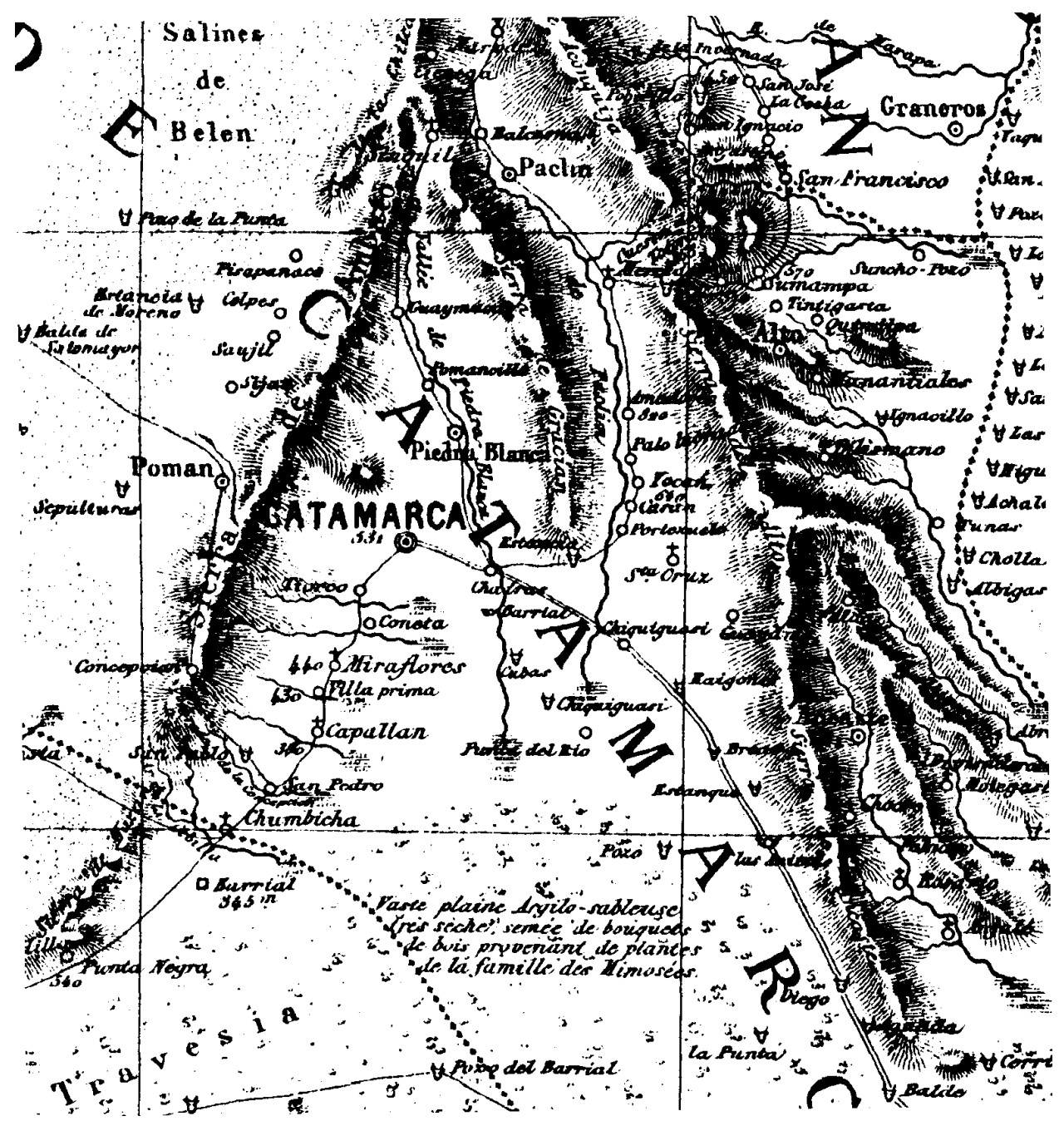

Fig. 16 - Los sitios llamados Chiquiguasi, cerca de la ciudad de Catamarca (según Moussy, 1860-1866).

procedencia en general se desconoce con exactitud, han sido trabajadas con espacios perforantes que exigieron gran destreza del lapidario (Fig. 17 y 18).

Ambrosetti los agrupó entre los fetiches animales o illas, suponiendo que se trataba de llamas con mucha lana (Ambrosetti, 1899: 260, figuras 206 y 207). Núñez Regueiro los asignó a la cultura Alamito, en la zona de Andalgalá (1971: 32) y González los relacionó vagamente con ritos de fertilidad (1977: 232). Raffino les reconoce su carácter humano pero no la posición de rogativa; y señala una posible relación con el personaje del "sacrificador" de la cultura La Aguada o Ambato, cercana en espacio y tiempo de Alamito (Raffino et al., 1997: 26). 


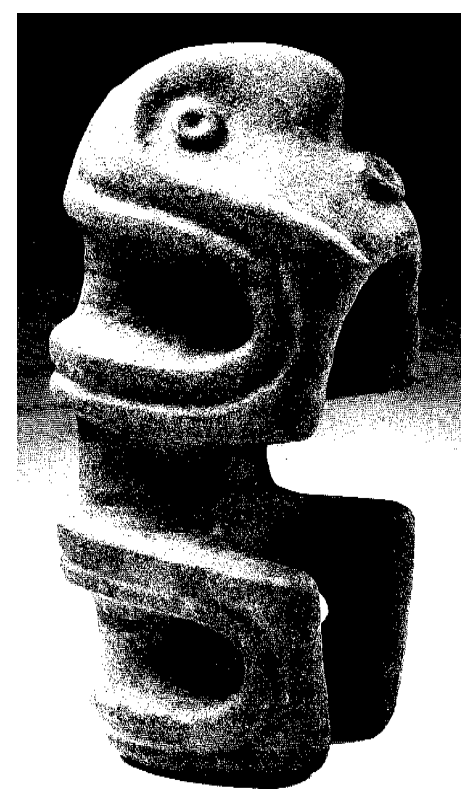

Fig. 17 - "Ídolo suplicante" tallado en roca diorítica; alto: $32 \mathrm{~cm}$., peso: 6,2 kg. Museo de La Plata, colección Moreno No 1928 (según Raffino et al., 1997: láminas II y XII).

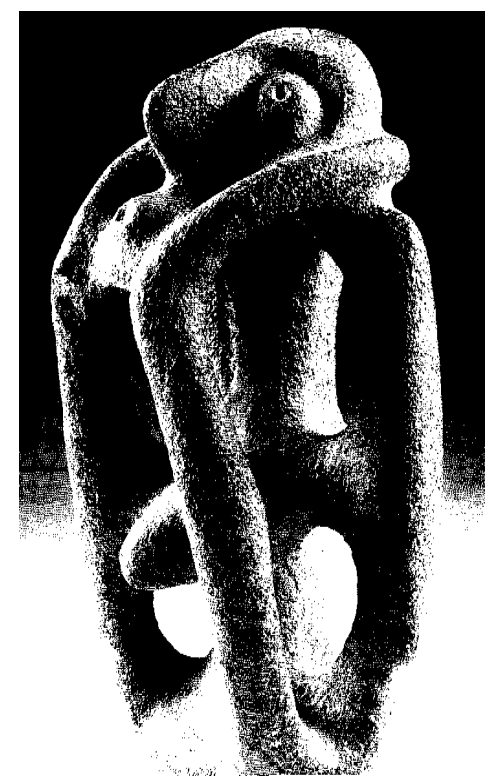

Fig. 18 - "Ídolo suplicante" tallado en roca diorítica; alto: $30 \mathrm{~cm}$., peso: 4,7 kg. Museo de La Plata, $N^{\circ} 8391$. Procedencia: dep. Paclín, provincia de Catamarca (según Raffino et al., 1997: lámina 1). 
En nuestra opinión, los "suplicantes" son esculturas que representan, con gran economía de rasgos, personas arrodilladas, que elevan el rostro, manteniendo los ojos abiertos y sosteniendo la cara entre las manos al tiempo que silban. Por eso nos interesa señalar el hallazgo de una de estas piezas en una zona relacionada con chiqui.

\section{4. Nombre de animal}

El padre Cobo decía que:

"Andan los papagayos a bandadas con gran vocería y hacen mucho daño en los sembrados, si no se pone cuidado en guardallos; y lo hicieran mucho mayor, si fueran ladrones callados y no tan vocingleros, porque avisados los labradores de las voces que vienen dando, acuden con tiempo a defender sus sementeras. Llámanse los papagayos grandes, en la lengua general del Perú uritu, y los pequeños, chiqui." (Cobo, 1964[1653], I: 327-328) (destacado nuestro).

Garcilaso, por su parte, contaba que:

"En los Antis se crían los papagayos. Son de muchas maneras ... Los indios en común les llaman uritu; quiere decir papagayo, y por el grandísimo ruido enfadoso que hacen con sus gritos cuando van volando, porque andan en grandes bandas ... Salen los papagayos de los Antis al tiempo que por todo lo raso del Perú está en sazón la zara, de la cual son amicísimos; hacen gran estrago en ella; vuelan muy recio y muy alto; las guacamayas porque son torpes y pesadas, no salen de los Antis. Andan en bandas, como se ha dicho, mas no se mezclan los de una especie con los de otra, sino que cada diferencia anda por sí." (Garcilaso, 1985[1609], II: 195-196).

Guamán Poma graficó esta circunstancia clara y dramáticamente: una bandada de loros abatiéndose sobre un maizal cuyos cuidadores, cubiertos con pieles de zorros, tratan de ahuyentarlos con hondas. Había otros depredadores pero ninguno tan numeroso como los loros; de todos modos, su presencia presagiaba la escasez, cuando no el hambre, de la comunidad que sufría la invasión (Fig. 19).

A diferencia de los guacamayos (¿guaca camayoc?), los loros tenían la particularidad de aprender a hablar, pero esto no los hacía más simpáticos. Cuentan que cuando Cahuillaca huyó hacia el mar con su hijo, Cuniraya Viracocha la iba persiguiendo preguntando a cada animal que encontraba qué rumbo llevaba su amada y si estaba cerca; según la respuesta, el dios bendecía o maldecía a cada uno. Cuando le tocó el turno al loro, éste le dijo:

"Ella ya venció una gran distancia; no la encontrarás". Cuniraya le contestó: "Tú caminarás gritando siempre demasiado; cuando digas: "destruiré tus alimentos", los hombres, que han de odiarte, te descubrirán por los gritos y te espantarán; vivirás padeciendo." (Ávila, 1966[¿1598?]: 27; Taylor, 1987: 53 y 67$)$.

Los frailes agustinos de la diócesis de Trujillo durante su evangelización encontraron un 


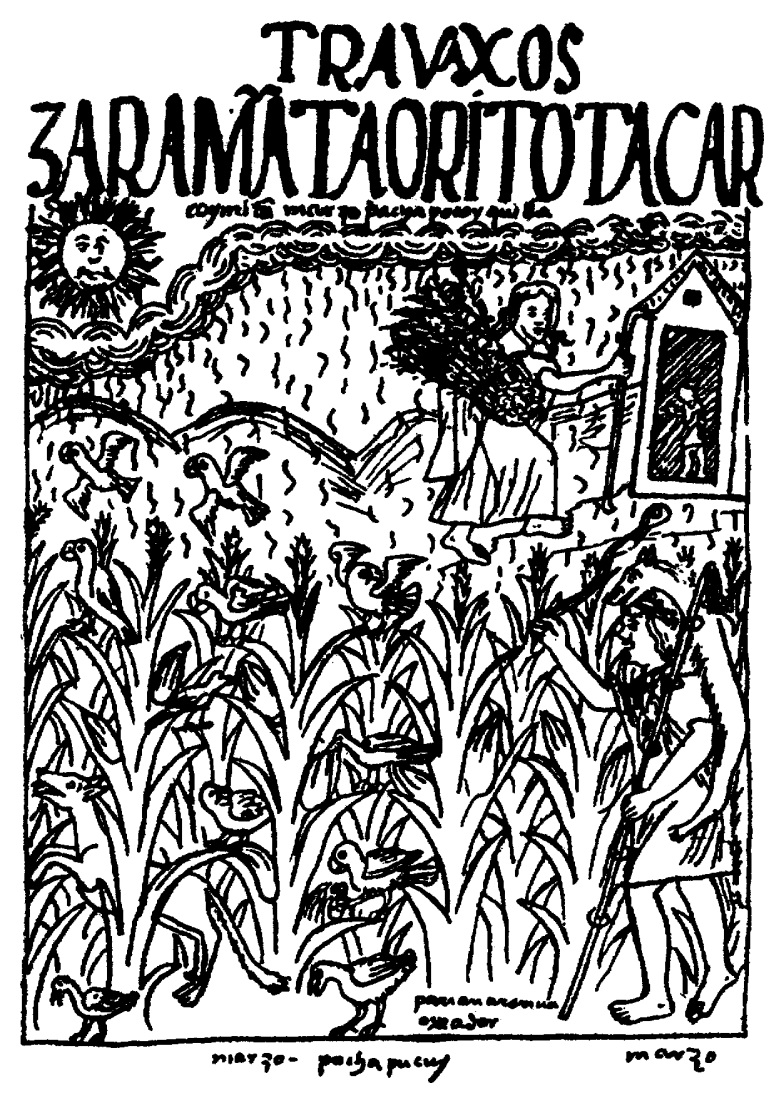

Fig. 19 - Bandada de loros abatiéndose sobre un maizal mientras un oxeador cubierto con una piel de zorro(?) trata de ahuyentarlos revoleando una honda.

“... ídolo llamado Páucar: éste era hecho como papagayo, hecho de barro a reverencia del demonio, porquél se hizo papagayo, y a vista del pueblo se metió debajo de la tierra. Y allí, en aquel lugar, hicieron el edificio y guaca, como papagayo, para acordarse de aquella maravilla quel demonio había hecho. A ésta [guaca] tenían gran reverencia y le ofrecían gran cantidad de chicha: quebrantóse y derribaron los padres el edificio; y todo lo que había quitaron, con los criados que había." (Agustinos, 1918 [c.1560]: 36; 1992: 30).

Parece que el ídolo Páucar (18) estaba al norte de Huamachuco, en el pueblo homónimo (Castro de Trelles, 1992: 30 nota 54), en la ladera este de la cordillera, bajando hacia el río Marañón, desde donde llegarían los loros a comer el maíz. La huaca debió ser importante: tenía criados.

(18) "Paucarcuna. Diversidad de colores de plumas (Anónimo, 1951[1586]: 69; Gonçalez Holguin, 1952[1608]: 281-282). También incluye el concepto de "cosa fina, preciosa, agradable, apetecible". 
También en Quillarumi (Huánuco), más hacia el sur pero a una altitud similar, se encontró una pictografía representando un loro (Pulgar Vidal, 1976: $\mathrm{N}^{\circ} 42$ ), rodeado de círculos con puntos, tal vez una estilización del maíz (Fig. 20).

La asociación de este animal con la facultad de hablar también es parte de otro relato recogido durante la evangelización: en la sierra sur, cerca del Cusco, en el pueblo de Huancaraime había una huaca que daba oráculos; cuando Mancocapac fue a consultarla le dijo que no lo recibiría porque no era inca legítimo, así que el Inca ordenó tirarla cerro abajo pero

“... Cuando fueron a menear la piedra salió de ella un papagayo muy pintado, y fue por el cerro adelante volando. Y aunque mandó el Inga que con piedras, y ayllos, o libis le siguiesen, no le alcanzaron; antes, llegando a una gran piedra, [ésta] se abrió y le encerró en sí, y se volvió a juntar como antes estaba. Y estas dos piedras de donde salió y entró el papagayo son muy temidas." (Arriaga, 1968[1621]: 226).

Entre las piezas de alfarería de las culturas prehispánicas de la costa peruana hay figuras de loros en bulto o dibujados, en general asociados con choclos, pero en un tiesto inca las plantas de maíz estaban amenazadas por unos insectos que las destruían desde la raíz (Fernández Baca, 1989: figura 89) (Fig. 21).

En la cuenca del río Pampas, todavía se usaba a comienzos del siglo XX en ceremonias agropecuarias, un kero de madera con la figura de un loro en actitud de aterrizar, dibujado en la franja intermedia del mismo (Soldi, 1997: figura MO-10393) (Fig. 22).

En el área andina argentina, en uno de los niveles ocupacionales de un sitio temprano llamado Palo Blanco (19) se encontró un Ara sp. que presentaba signos de haber sido cazado joven y mantenido en cautiverio como animal doméstico (Sempé, 1977a: 214). Uno de los rasgos de la cultura Saujil era el cultivo de un maíz pequeño, Zea mays vr. Microsperma (Sempé, 1977b: 59).

También abundan las representaciones de loros en la alfarería de la cultura de La Aguada, del Período Medio (20) cuyos diseños están grabados con líneas muy finas sobre piezas de paredes delgadas que, en general, son de color gris o negro.

En opinión de Montes, en algunos casos eran falcónidos (sic) y en otros, cóndores, o figuras ornitomorfas (González \& Montes, 1998: XXI y XXII) (Fig. 23). Por su parte, González aceptó la interpretación de Debenedetti de que una de estas figuras era la de un loro (González \& Montes, 1998: figura 176). En la colección Rosso hay una pieza Aguadaen cuya superficie están grabados loros aprestándose a aterrizar (Rosso, 1975: figura 17) (Fig. 24).

(19) El sitio Palo Blanco, en la actual provincia de Catamarca, corresponde a la cultura Saujil, que se desarrolló en el Período Temprano, 600 a. C.- 500 d. C. (Sempé, 1977a).

(20) La cultura de La Aguada es más conocida por el trabajo de Alberto Rex González, quien la ubicó en el Período Medio, entre los años 500 y 900 d.C. (González \& Montes, 1998: 68), en un ámbito geográfico que abarcaba algunos sectores de las actuales provincias de Catamarca (valles de Hualfín, Abaucán, Ambato y valle central) y La Rioja (Anillaco, Vinchina y Bañados del Pantano) (González \& Montes, 1998: 67). Hacia el norte, dentro del valle Calchaquí, Rodolfo A. Raffino et al. (1979-1982) también encontraron alfarería Aguada. 


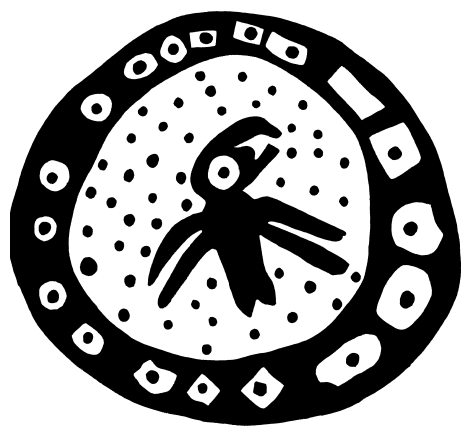

Fig. 20 - Pintura rupestre de Quillarumi, Huánuco (según Pulgar Vidal, 1976: $\mathbf{N}^{\circ}$ 42). Representa un loro volando, rodeado de círculos con punto interior, tal vez una estilización del maíz.

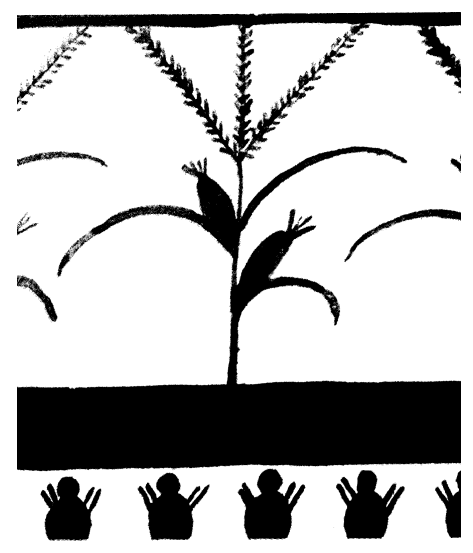

Fig. 21 - Alfarería incaica. "Plantas de maíz... la tierra está representada por una faja marrón bordeada con fajas negras y debajo de ésta, insectos destructores de la raíz llamados "khuchi-khuchi”." (según Fernández Baca Cosio, 1989: figura 89).

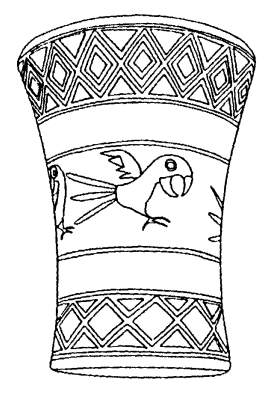

Mo- 10393

Fig. 22 - Kero de madera pintada usado hasta principios del siglo XX en Apurímac durante las ceremonias relacionadas con la esquila de las llamas; el cuerpo de los loros es rojo, las plumas de las colas son verdes y los picos y garras son color amarillo pálido (según Soldi, 1997: figura MO-10393). 


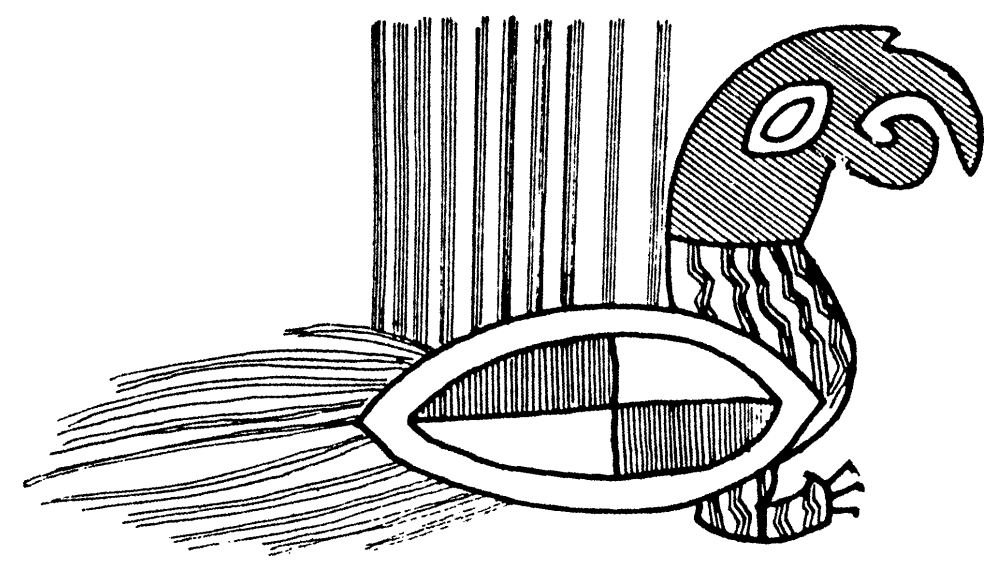

Fig. 23 - "Estilización de un loro. Puco estilo Hualfín gris grabado. Colección B. Muñiz Barreto, Museo de La Plata. Cementerio Orilla Norte de La Aguada." (según González \& Montes, 1998: figura 176). Alto: 110 mm., Museo de La Plata No 12658 (Debenedetti, 1931: 46). El cuerpo del ave tiene escaques en señalados con dos tramas distintas.

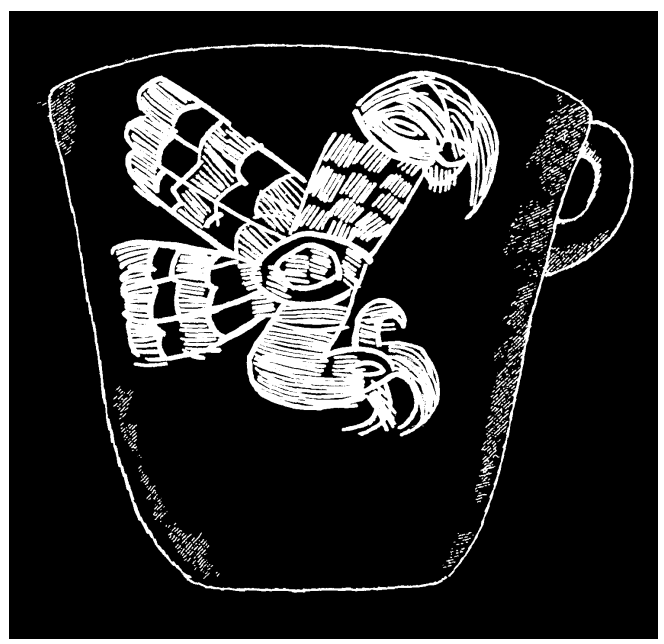

Fig. 24 - "Vaso con decoración incisa, de color blanco, que representa loros. Cultura Aguada. Procedencia Catamarca.” (Dibujo de Susana Albarello según Rosso, 1975. figura 17). La pieza es de color negro.

Como una variante del tema, en algunas piezas Aguada están juntos loros y tigres, y a veces también reptiles. Uno de estos casos es una placa metálica adquirida por Ambrosetti en Tolombón (valle de Yocavil o Santa María), donde se ve a un personaje que viste un ипси con tres fajas de diseños verticales diferentes, uno de ellos acuático; a la altura de los hombros lo flanquean dos tigres y a la altura de la cintura, uno a cada lado, hay loros en actitud de trepar (Ambrosetti, 1904: figura 79; González, 1992: 111) (Fig. 25). 


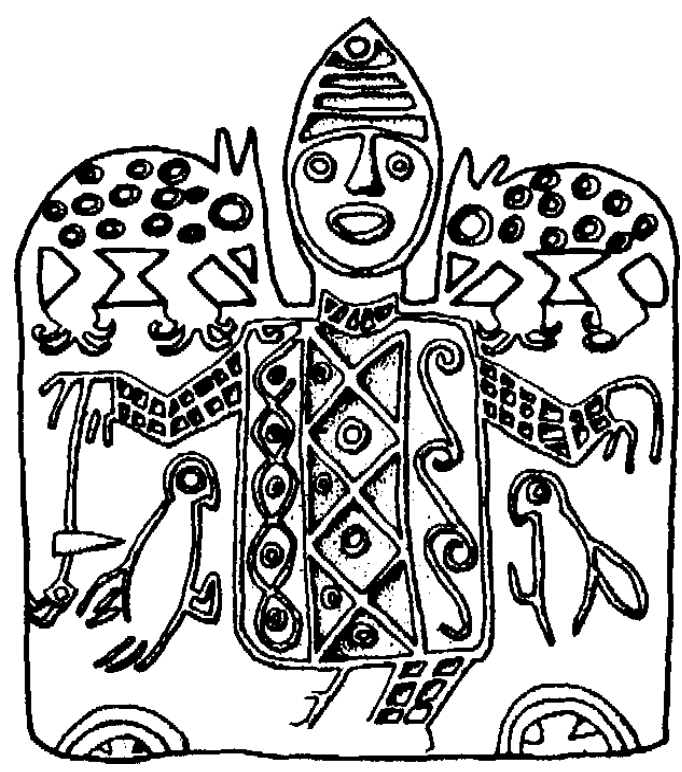

Fig. 25 - Placa de metal comprada por Ambrosetti en Tolombón, valle de Yocavil, o Santa María (según Ambrosetti, 1904: figura 79 y González, 1992: 111).

En cambio, en otra placa de bronce hallada en Riberalta, sobre el río Beni (Bolivia), los loros se encuentran sobre los hombros del personaje ¿hablándole? (Posnansky, 1957: 127 y plancha LXXXa); en su ropa hay diseños de espirales, relacionados con el viento (Fig. 26).

También en una tela estilo Huari se ven tigres, monos y loros formando parte de una compleja escena con cabezas humanas y el personaje de dos cetros (The textile art of Perú, 1991: 175). En todos estos casos (en tejido, alfarería y placas de metal), se trató tal vez de una escena que transcurría en las tierras bajas, hacia el este de la cordillera. Todas estas representaciones de escenas seguramente remiten a historias conocidas entre quienes usaban estas piezas (Gentile, 1999c: capítulo 1) (Fig. 27).

En cuanto a las manoplas de bronce, éstas fueron fechadas entre 1200 y 1550 d.C. (González \& Núñez Regueiro, 1968-1969: 258) (Fig. 28). Algunas tienen dos loros en relieve sobre la franja de metal que proteje el puño cerrado y en un extremo tienen punzones que semejan choclos; la poca resistencia a los golpes que ofrecen estas piezas nos permite suponer que fueran usadas en luchas más bien mágicas.

En el sitio Pucará de Tilcara, donde se encontraron piezas de clara influencia incaica, se halló una vasija de alfarería en forma de loro (que contenía un cráneo natural del ave), en el ángulo exterior formado por las paredes de dos habitaciones, sobre el lado este de los recintos, es decir, "mirando" hacia la región de las tierras bajas (Fig. 29). En Pucará de Tilcara se encontraron también esqueletos de zorro (p. 49) y cóndor (p.69), además de cabeza de ciervo (p. 51), de puma (p. 67), caparazón de mulita (p. 51), y un ave sin especificar (p. 74), todos ellos formando parte de entierros, no de restos de cocina (Debenedetti, 1930). 


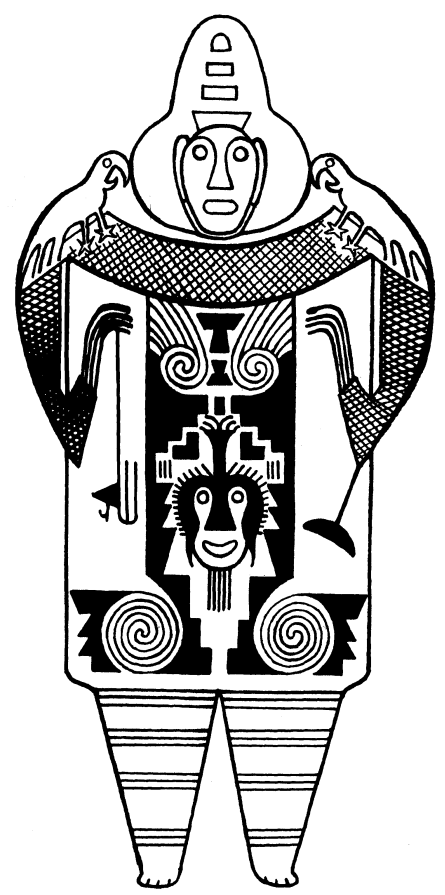

Fig. 26 - Placa de metal procedente de Riberalta, río Beni, Bolivia (según Posnansky, 1957:127 y plancha LXXXa).

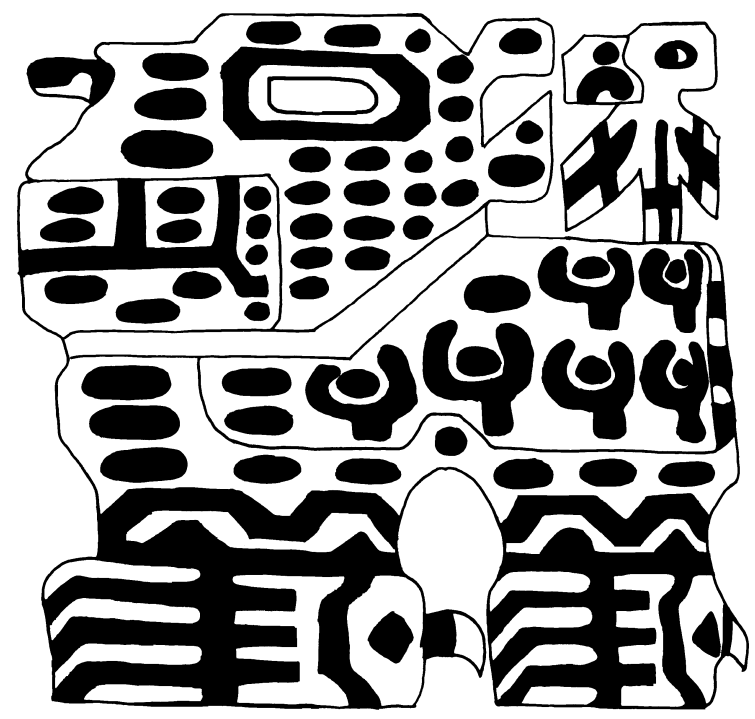

Fig. 27 - Uturuncu y un loro volando en una tela Huari con escenas que incluyen cabezas humanas y el personaje de los dos cetros (dibujo de Fátima Hatano según Textile Art of Peru, 1991: 175). 

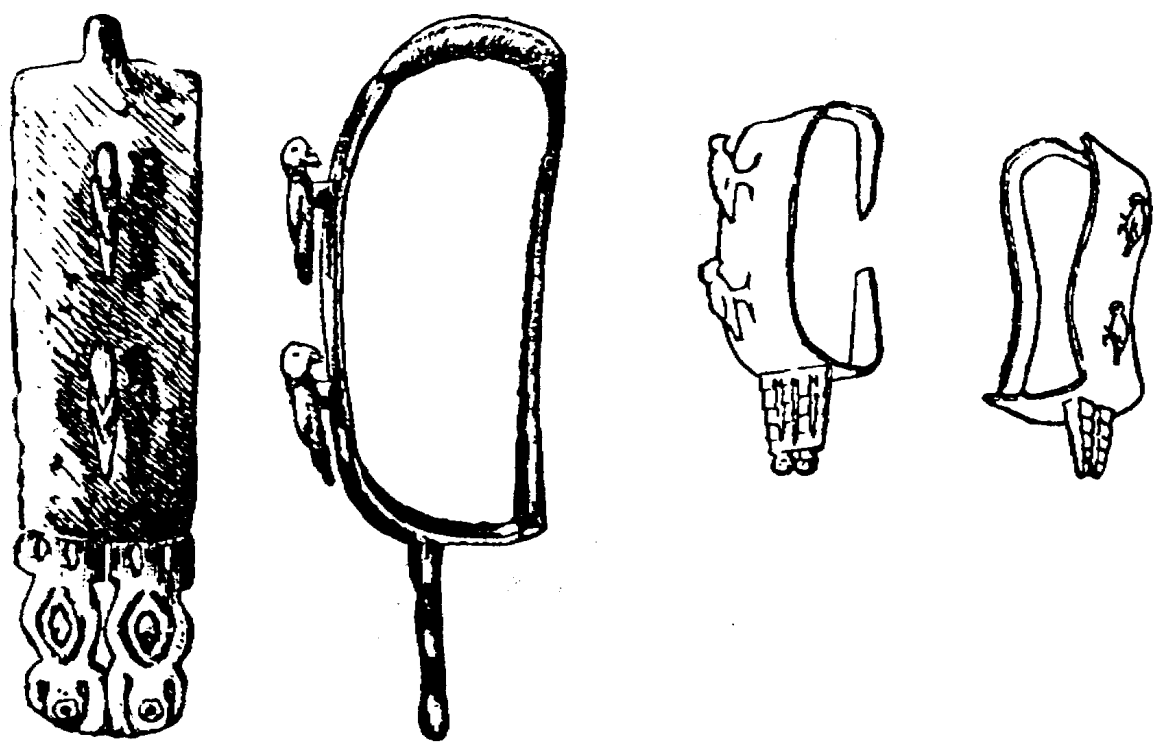

Fig. 28 - Manoplas de bronce, procedentes del noroeste argentino, con figuras de loros en bulto, una de ellas con dos choclos en relieve sobre el apéndice agresor (según González \& Núñez Regueiro, 1968-1969: Lámina XXIX, 1, 2, 3).

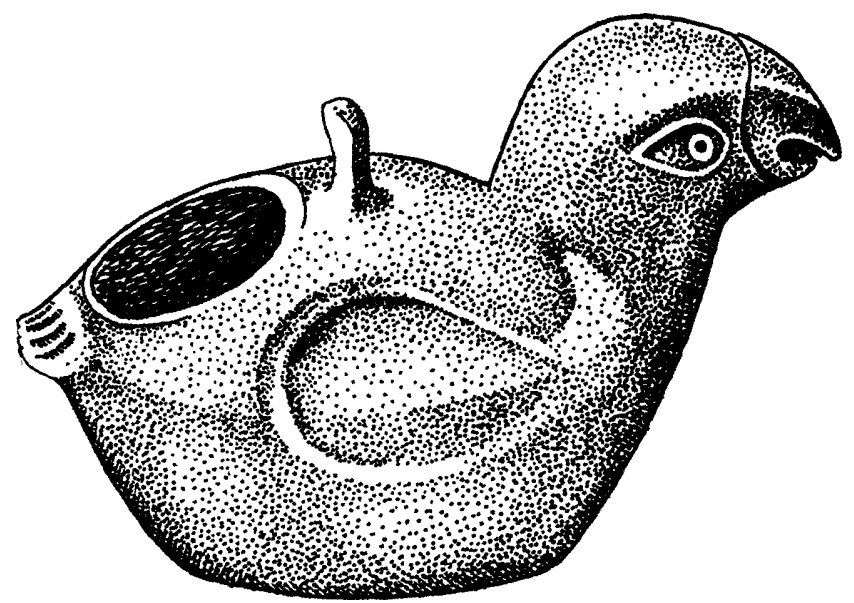

Fig. 29 - Vasija de alfarería representando un loro que contenía un cráneo de esta ave en su interior, hallada en el sitio Pucará de Tilcara; alto aproximado: $15 \mathrm{~cm}$. (dibujo de Susana Albarello según Bregante, 1926: figura 118). 
En la colección Uhle del Museo de Berlín, Salvador Debenedetti fichó un alfiler procedente de Tilcara, en cuya parte superior había representada un ave, tal vez un loro, de 5,5 cm de largo, “... el convencionalismo del ave representada recuerda a las que se suelen ver en los tejidos de origen peruano”. (Fig. 30, 34 y 35)

Y agregaba que

"Las representaciones de loros sea en piedra, en barro, en cobre, en hueso o en madera son de un origen remoto y su generalización en América no puede dudarse. En el Perú Uhle las ha encontrado en Pachacámac en la cultura que precedió a los tiempos incaicos; en la región diaguito calchaquí es bien conocida su extensión y en las regiones de la llanura hasta en la misma ribera del río de La Plata es bien conocida esta representación. Es posible que sus orígenes haya que buscarlos en los tiempos en que las influencias entre los pueblos montañeses y los de la llanura eran mucho más poderosas que en los tiempos en que las naciones andinas llegaron a establecerse de una manera más o menos definitiva y con una organización más o menos completa." (Debenedetti, 1913?, III: 20-21).

Las representaciones de loros en piezas halladas en la ribera del río al que se refería Debenedetti, eran los apéndices zoomorfos de vasijas de cerámica, de formas generalmente globulares, cuya pasta no tenía antiplástico, pero con las superficies muy bien pulidas; se las encontraron en las tierras bajas e islas adyacentes al río Paraná. Si bien el animal más representado era el loro, toda la fauna regional compuesta de aves, reptiles y mamíferos estaba en el diseño, pocas veces de manera completa y más bien figuraba solo la cabeza, o ésta y la cola (Serrano, 1966: 123-125) (Fig. 31).

Estas piezas corresponden a la cultura prehispánica llamada Malabrigo o GoyaMalabrigo, relacionada también con los chaná-timbú etnográficos (González, 1977: 409 y siguientes) (Figura 32).

En cuanto al valle Calchaquí, en 1601 los loros continuaban haciendo estragos: cuando los evangelizadores Romero y Monroy llegaron a un pueblo que encontraron vacío, dudaron si no era una emboscada pero enseguida recibieron

“... aviso cierto que ... los indios del pueblo estaban de paz, y que solo avian abandonado sus viviendas, por irse à guardar sus sementeras contra las invasiones de los enxambres de papagayos, que se las iban talando, como suelen [hacer]..." (Lozano, 1970[1754]: 427) (Fig. 33).

\section{RESUMEN Y COMENTARIOS}

Lafone llamó fiesta o juego del chiqui a la pervivencia decimonónica de una rogativa prehispánica para obtener agua para las chacras de maíz, ceremonia que parece que paulatinamente se iba adaptando a los cambios sociales y medioambientales. Con harina de algarrobo y maíz se preparaban comidas y bebidas, según la época del año en que hubiera más disponibilidad de una u otra, con la ventaja de que los montes de algarrobos, hasta donde sabemos, no necesitaban del cuidado que sí requerían las chacras de maíz.

Esta fiesta, realizada en pleno verano, a la sombra de algarrobos y bebiendo aloja, pasó por diversas instancias de interpretación. 


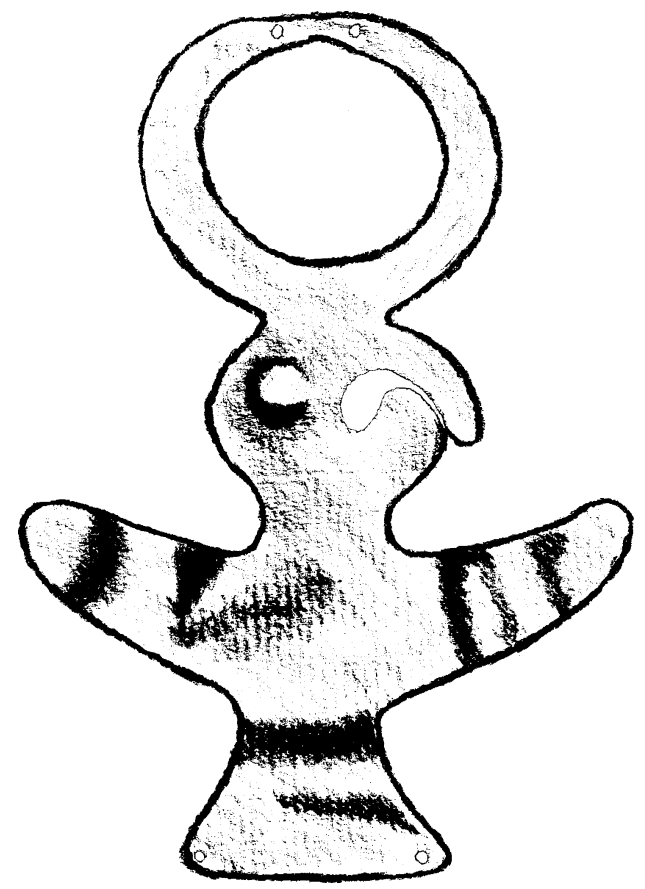

Fig. 30 - Figura de loro recortada en lámina de oro, con cuatro orificios para ser cosida en una tela. Alto: 11,5 cm. (dibujo de MG según González, 1977: figura 256).
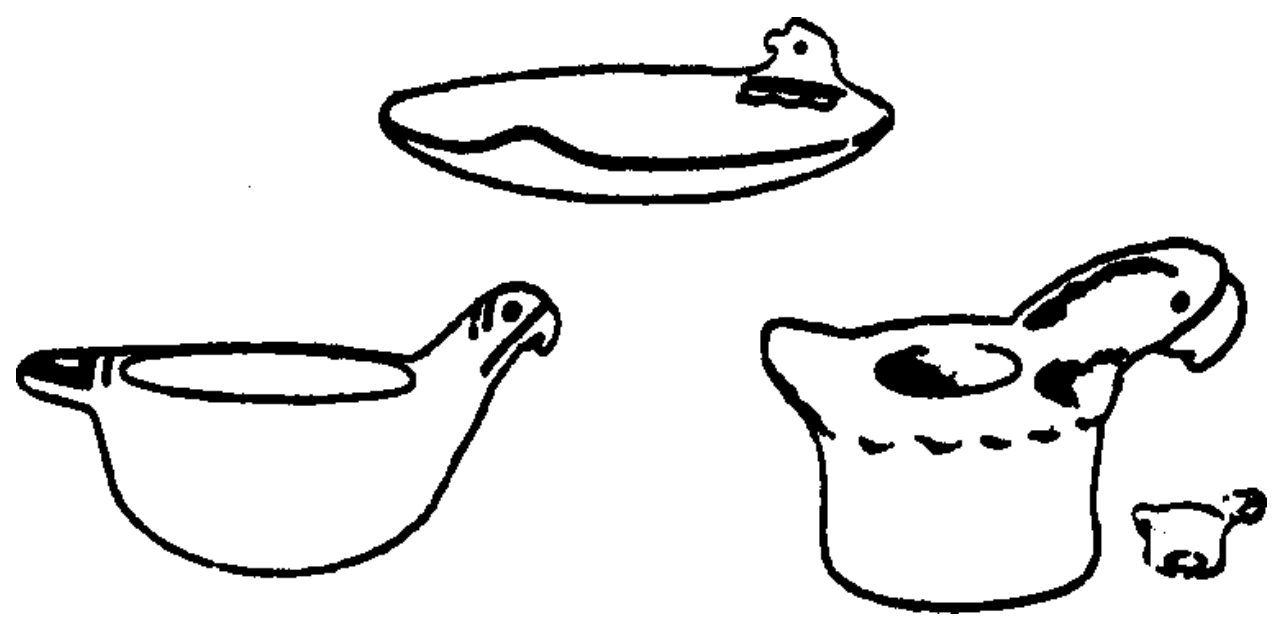

Figu. 31 - Alfarería de la cultura Goya-Malabrigo, costa del río Paraná, con representaciones de loros (según Serrano, 1966: figura 55). 


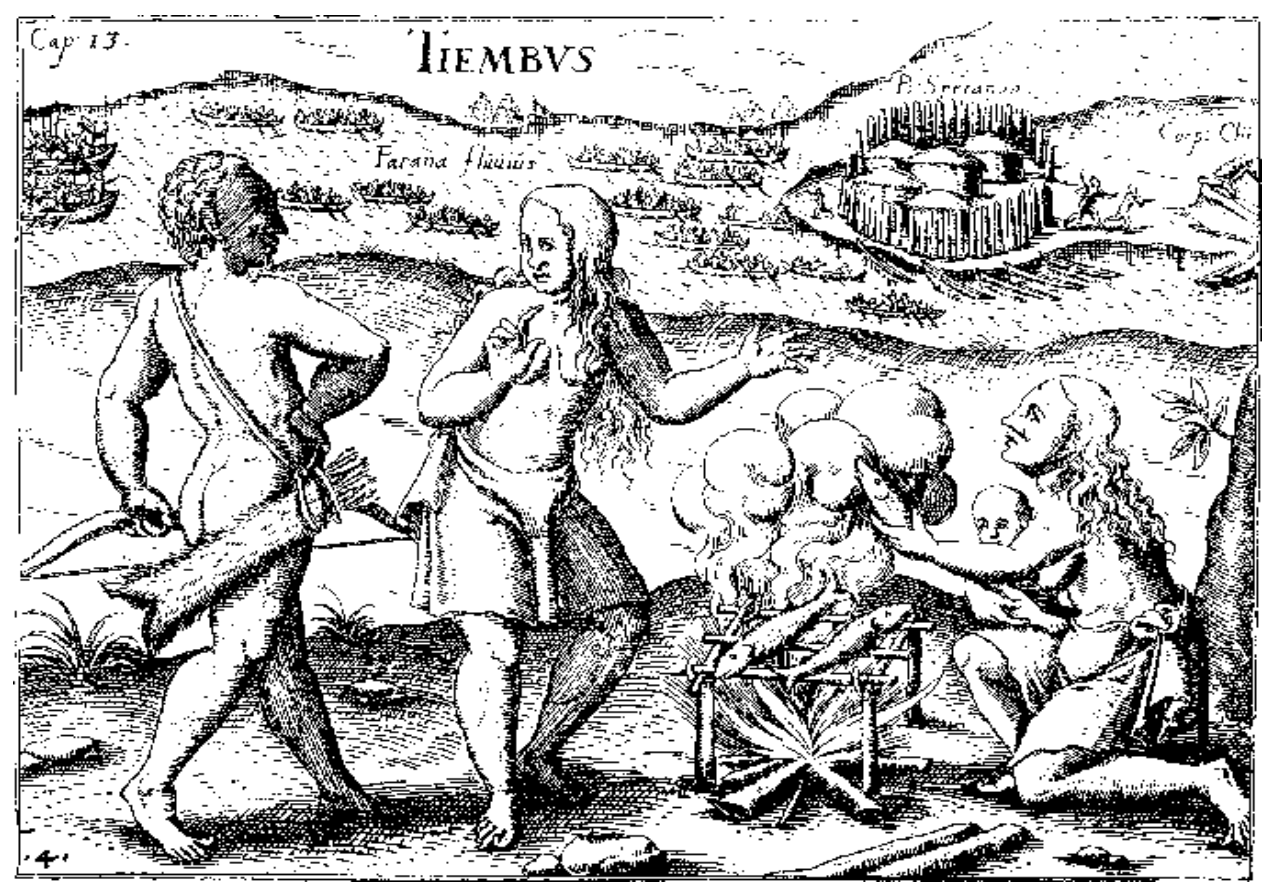

Fig. 32 - Indios timbú, habitantes de la costa del río Paraná. Al fondo, el fuerte Buena Esperanza. Grabado que acompañaba la primera edición de la obra de Ulrico Schmidel s/f[1554]: capítulo 13.

Al agregarle nuestro autor el artículo determinado quedó El Chiqui, y esto llevó a pensar sobre chiqui como una entidad antropomorfa y no como un concepto que podía ser evocado, entre otras, a través de una figura antropomorfa.

En los oasis de La Rioja y Catamarca los cultivos de maíz se echarían a perder si faltara el agua, de ahí la rogativa durante la época en que apuntaban las miesses para alejar lo chiqui, la desgracia, el peligro.

Si bien Lafone registró el sentido de la ceremonia ("conjurar la mala suerte en tiempo de seca ú otra calamidad”), punto que lo llevó a Montesinos y del que también partimos en nuestras indagaciones, en 1885 daba por hecho que la fiesta era una reliquia del gentilismo, es decir, era una pervivencia que transitó sin modificaciones la colonización europea del noroeste argentino. Así, redujo su trabajo a la traducción del canto, a cambiar opiniones con Quiroga sobre si el suri había sido o no una antigua representación de la nube y la lluvia, etcétera, quedando a cargo de él y de Ambrosetti lo relacionado con El Chiqui.

La distancia entre Lafone y sus informantes era muy grande (más con un intérprete de por medio), tanta como su interés por mantener una controlada trascendencia en cualquier acontecimiento ocurrido en el ámbito de sus propiedades y negocios. Ya anteriormente había preferido limitarse a explicar lo actual en base a lo antiguo, usando su información sobre dos casos de muertes rituales (sucedidas alrededor de 1860, a 


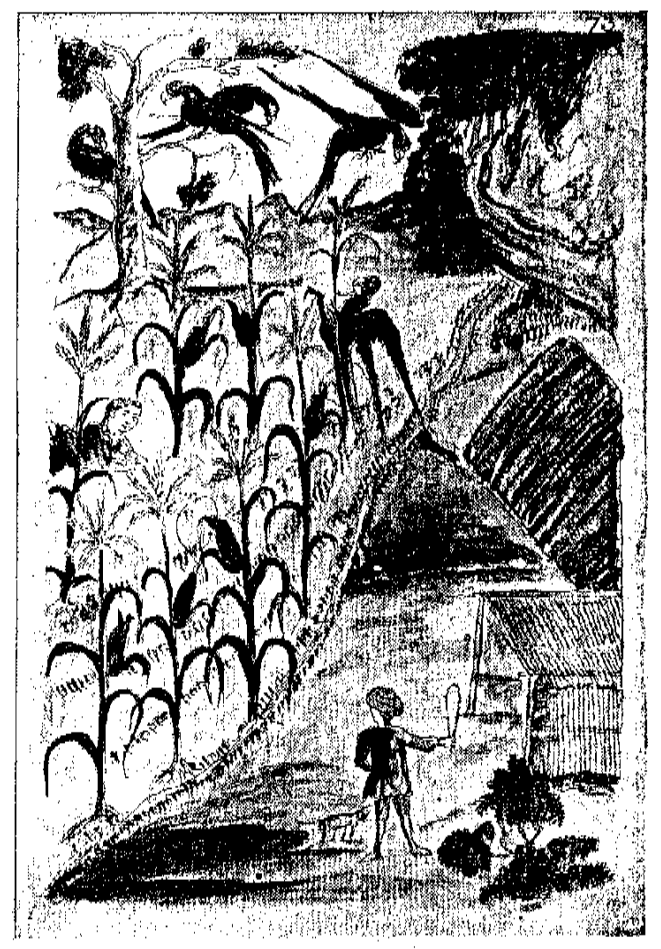

Fig. 33 - Loros en un maizal de Trujillo, según un dibujante anónimo del Obispo Martínez de Compañón, fines del siglo XVIII. Aguada propiedad del Banco Continental, Lima, Perú.

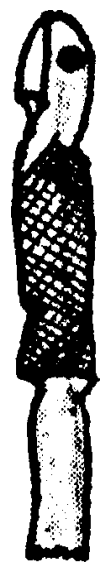

Fig. 34 - Figura de loro asentado en el extremo de un alfiler de hueso procedente de Paracas, II terraza (según Tello \&

Mejía Xesspe, 1979: figura 59, 7).

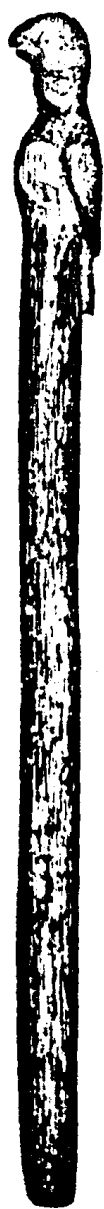

Fig. 35 - Insignia de madera con una figura de loro asentado en un extremo hallado en Niño Korin, Bolivia. Largo: 21,5 cm (según Wassén, 1972: figura 31). 
cuyos involucrados decía conocer personalmente tanto como al motivo), para respaldar su afirmación de que los habitantes actuales de la región eran tan salvajes como sus ancestros que habían realizado los sacrificios humanos que se encontraban en las urnas procedentes de cementerios prehispánicos, y que en 1859 perduraban representados por los muñecos de biscocho colgados del árbol del chiqui (Lafone, 1888: 253).

Cuando pidió al padre Vásquez que le consiguiera el texto del canto de los indios, la consecuencia fue que éstos negaron cualquier otra información porque la ceremonia estaba vigente, y no podían correr el riesgo de que se les impusiera una prohibición por parte de la Iglesia y las autoridades civiles que impidiera la realización de la fiesta. Por eso la insistencia de la hija de Cativa en 1938 acerca de que la fiesta había sido parte del Carnaval y que solamente se había realizado el chiqui hasta fines del siglo XIX, es decir, cada entrevistado trasladaba el tema al pasado y daba por cancelada una celebración que entendían que no era aceptada y podía ser motivo de burla, como le habían explicado a Quiroga claramente en Machigasta (1897: 550).

De todos modos, la autoridad de Lafone sobre el tema era tan grande que en las “Instrucciones ..." que acompañaron la Encuesta de 1921 el asunto del chiqui fue puesto como ejemplo de fantasmas, duendes, fiesta, juego y canto popular.

Todas estas circunstancias nos privaron de conocer más detalles y nos obligaron a seguir muchos rumbos diferentes, aunque no diversos, durante nuestras indagaciones.

\section{1. Un poco más sobre los calchaquíes}

Chiqui era voz quechua del Cusco que según los diccionarios de los siglos XVI y XVII se refería a todo lo relacionado con la envidia, el peligro, la suerte adversa y la desgracia inminente que se observaba en los presagios.

Conservando ese concepto, Chiqui fue parte del segundo nombre, o apodo, de mujeres y hombres. Pero no solamente las personas podían cambiar su nombre en circunstancias especiales; también los lugares y los grupos indígenas enfrentaban esa posibilidad (Gentile, 1999: capítulo 4).

En los mismos vocabularios, una de las entradas decía "Chiquicuni, gui, o calchani, gui. Inuidia tener." (Santo Tomás, 1951[1560]: 262). No encontramos allí "calchani", pero el Anónimo decía "Calchani, segar" (1951[1586]: 20). También tenemos: "Callchani: recoger las miesses o cortarlas. / Callchasca. El rastrojo. / Callchayppacha. La cosecha." (Gonçalez Holguin, 1952[1608]: 44); "Segador de mayz. Callchak (Gonçalez Holguin, 1952[1608]: 667). Guamán Poma decía "zegador Callchac" (1980[1613]: 1040), voz esta última, relacionada con los calchaquíes, cultivadores del valle homónimo. Por otra parte, sobre el Anónimo de 1586 existe una fuerte presunción que su autor haya sido el jesuita Alonso Barzana (Escobar Risco, 1951: XIII), que luego estuvo en el valle Calchaquí y redactó un diccionario cacán que todavía no se encontró.

Pero la voz calchani como tener envidia podría estar señalando que callchac o calchac era también, además un trabajo u oficio, uno de los tantos apodos que los incas acostumbraban poner a los pueblos rebeldes transterrados luego de alguna sublevación (Gentile; 1992; 1995; 1999c). 
Dónde y en qué momento se habría originado este sobrenombre no lo sabemos todavía pero la relación de calchani con una situación desgraciada, chiqui, como el desarraigo (que cambiaba todas las reglas de reciprocidad e intercambio), merece ser tomada en cuenta porque Lozano decía que los calchaquíes eran oriundos del valle (Lozano, 1970[1754]: 423), como era de esperar que lo afirmara la gente de la parcialidad que lideró una importante rebelión alrededor de 1560 para justificar sus derechos en el marco de las recién llegadas instituciones españolas.

\section{2. Espacio y tiempo}

1. Una mirada rápida nos deja ver que a mediados del siglo XIX, en la provincia de La Rioja se le dedicaba a El Chiqui una fiesta en tanto que en el Cusco, en la misma época, chiqui parece que era nada más que un adjetivo que calificaba los días infaustos (21).

Y en el siglo XX, en Ecuador, la expresión chiki se usaba durante un juego de velorio, el huayro, para indicar una mala tirada del dado y que el difunto no estaba ayudando a ganar a los jugadores porque entre los presentes se encontraba alguno con quien se había enemistado (Karsten, 1972: 244) (22).

Pero en el siglo XX, en el NOA, todavía se recordaba la fiesta y el juego del chiqui en los mismos lugares donde habían sido prohibidos ochenta años antes. ¿Se recordaba, nada más?

2. Si bien Lafone consideraba la fiesta como una reliquia, no se preguntó qué tan antigua habría sido, pero su asociación directa con la recolección de las vainas de algarroba para fabricar aloja nos facilitaron la búsqueda.

Sobre este aspecto nos podría orientar una carta del gobernador del Tucumán Alonso de Rivera, fechada en 1608, donde relataba al rey los inconvenientes provocados por la quita de los tenientes de naturales y decía, por ejemplo, que los indígenas no alcanzaban a defenderse de los daños que recibían de “... los encomenderos, puebleros y otros mestizos y mulatos...”. Pero estos tenientes de naturales parece que también protegían a los indios de sí mismos

“... especialmente en tiempo del algarroba que son los meses de Diciembre, Enero y Febrero, [cuando es] la fuerza de ella y cuando ellos la cogen y hacen sus borracheras en las cuales se hieren y matan y hacen mil estragos y ofensas de Dios sin perdonar parientes aunque sean muy cercanos y todo esto con tanto exceso que en esta ciudad [Santiago del Estero] donde estoy yo y mi teniente y dos alcaldes ordinarios y el alguacil mayor y menor y otros ministros de justicia y sus propios encomenderos que todos procuramos quitar los desórdenes que digo y las borracheras de donde proceden quitándoles

(21) "Los martes y viernes son Chiki, días infaustos, ominosos, desgraciados, especialmente los martes, y también los son los siguientes: 11, 15 y 20 de enero; 1, 7, 8 de febrero; 15, 16, y 20 de marzo; 7 y 15 de abril; 7, 15 y 17 de mayo; 6 de junio; 13 y 15 de julio; 1,18 y 20 de agosto; 15 y 18 de septiembre; 6 de octubre; 15 y 17 de noviembre; y 6 y 7 de diciembre." (Valcárcel, 1952: 24).

(22) Tomoeda (1994) describió ciertos ritos del mes de agosto relacionados con las llamas realizados en algún lugar de los Andes; uno de ellos, el chikitipi, tenía por finalidad limpiar las cosas y las personas contaminadas. 
el agua (23) y quebrándoles la basija en que la hacen [la aloja] y prendiendo $\mathrm{y}$ castigando a muchos de los que se hallan culpados y todos no somos parte a que no se maten ni descalabren ni hagan los demás desórdenes que arriba digo, por esto podrá vuestra Maestad juzgar lo que pasará en los pueblos donde no hay españoles ni ningún ministro de justicia que se lo estorbe." (Larrouy \& Soria, 1921: VII-VIII).

Continuaba diciendo el gobernador que sería muy bueno contar con más sacerdotes, etcétera.

Al referirse a las costumbres de los indios del valle de Londres, también a principios del siglo XVII, decía el padre Lozano que

"Eran dados por extremo a la embriaguez, que celebraban con públicos convites, por diversos títulos según los diversos fines de la convoctoria; unos intitulaban bailes cuando eran en señal de alegría; otros llantos, cuando se juntaban á llorar la muerte de algun pariente, y en ambas ocasiones se cometian abominables escesos, resultas forzosas de la embriaguez..." (Lozano, 1874-1875[1745], I: 428-429).

En otro texto decía que

“... los Calchaquíes, que eran gente, por lo comun, bien agestada, altos, blancos, y fornidos; pero reyanba en ellos con excesso el vicio de la embriaguèz, para que daba fomento la abundancia de maìz, y algarroba, que lleva el Paìs..." (Lozano, 1970[1754]: 424).

También, más o menos para la misma época, había una "provincia de los algarrobales" donde vivían los indios que servían a la ciudad de Córdoba y que en alguna oportunidad se habían alzado contra los españoles (Lozano, 1874-1875[1745], I: 405; Montes, 1950: 68, 102, 106).

El tema del "vicio de la embriaguez" entre los indígenas estuvo relacionado con el buen funcionamiento de la densa red de relaciones de reciprocidad e intercambio que se sustentaba tanto en un sistema de parentezco que los españoles no aceptaban, como en las largas negociaciones y demostraciones de generosidad. Incidir sobre ese punto significaba también hacerlo contra la organización sociopolítica indígena con la finalidad de reemplazarla por la europea, de ahí que es prudente poner entre comillas esta remanida frase, sin dejar de aceptar que las ceremonias y reuniones indígenas iban acompañadas con abundante bebida (Saignes, 1993, entre otros).

Siempre a principios del siglo XVII, una costumbre de los indios de Londres relacionada con la agricultura contenía algunos elementos de la fiesta del chiqui:

“... al apuntar las mieses, celebraban un género de sacrificio, intitulado en su idioma pilla-jacica, y era salir á caza; y del primer guanaco ó

(23) Carrizo (1942, I), recogió un relato en Aimogasta acerca de cortar el agua a los indios, o más bien, desviarla hacia otra acequia; el asunto parecía relativamente cercano en el tiempo y nos llevó a pensar que podía tratarse de un simple robo de agua justificado por la celebración indígena, una sospecha de sublevación o cualquier otra excusa más o menos verosímil. La Rioja cuenta con Ordenanzas de aguas desde, por lo menos, 1611, a raíz de los pleitos que los vecinos tenían sobre este tema (Doucet, 1976; 1983) (nota de MG). 
liebre (24) que cogiesen, guardar la sangre, con la cual rociaban los frutos primeros, que colgados de algun algarroba, ú otro árbol, los consagraban al demonio..." (Lozano, 1874-1875[1745], I: 430).

Si bien depende de la época de siembra, en el NOA las miesses comienzan a salir en los meses de verano, es decir que el pilla-jacica se llevaría a cabo durante esa época del año. Además, la sangre del animal cazado debía guardarse en algún recipiente y en un sitio especialmente destinado para, luego de la cosecha, rociar los primeros frutos puestos en un sitio también determinado. Es decir, una ceremonia organizada, con espacios y tiempos determinados. Además, en quechua chantasca pillu era una guirnalda (Anónimo, 1951[1586]: 34; Gonçalez Holguin, 1952[1608]: 96), y pillu era como una corona de lana que que se llevaba en la cabeza, un llauto (Anónimo, 1951[1586]: 70; Gonçalez Holguin, 1952[1608]: 285).

La importancia de la algarroba era tanta que en 1666, recién terminada la guerra de Calchaquí y estando los acalianos transterrados en Nuestra Señora de Talavera de Esteco, población lindera del Chaco, una noche se fueron todos por el llano para no sufrir el calor diurno. Allí hubieran podido atajarlos los españoles, cosa que no hicieron a pesar de no ser un viaje de un solo día; cruzaron el nevado de Aconquija y entraron al valle Calchaquí, donde el gobernador de Tucumán los esperaba en los algarrobales sabiendo que iban a la recolección anual de las vainas, y en base a esta "huída" pudo repartirlos como esclavos entre sus soldados en vez de tenerlos como indios aliados en Esteco (Gentile, 1997: 329).

Si consideramos que esa fiesta estaba relacionada con el maíz y la algarroba, nuestra área colonial se amplía con los relatos anteriores y así llegamos hasta Esteco, Santiago del Estero y Londres, zonas donde casi no hay montes de ese árbol en la actualidad, ni chacras de maíz importantes.

3. La aparente solución de continuidad entre los datos del siglo XVII y 1859 sugiere que la fiesta fue acallada por la evangelización y que los sacerdotes sabían que se realizaba en sitios apartados, pero la toleraron mientras ninguna autoridad les exigiera actuar enérgicamente. Así fue como el padre Vásquez no tuvo dificultad en encontrar quien le dictara la letra del canto del chiqui. Sin embargo, ante una situación especial (catástrofe climática, visita pastoral), la fiesta se manifestó en forma tan pública que Maubecin no tuvo otra alternativa que prohibirla expresamente.

Algo similar sucedió en el caso de otra ceremonia prehispánica que se llevaba a cabo en Cochabamba a fines del siglo XVIII; un buen día, las autoridades españolas iniciaron un expediente, que no llegó a tramitarse más allá de su envío al virrey en Buenos Aires, en el que se pedía que cesara de inmediato dicha celebración que, según decían los testigos, databa de un tiempo inmemorial. Ahora bien, ¿cómo se había llevado a cabo durante los casi 300 años de colonización una ceremonia que incluía el paseo de cadáveres y calaveras por medio de la ciudad sin que a nadie le llamara la atención? (Gentile, 1994; 1999c).

(24) Lozano se refiere más bien a la viscacha, porque la liebre es un animal europeo introducido en el NOA a fines del siglo XIX (Quintanilla et al., 1980[1973]: 13). El indio Peralta también hablaba de cazar liebres. 
La preocupación andina se relacionaba con sucesos que no se podían controlar a través de su tecnología, sino que había que pactar con quienes los provocaban para que no los dañen (viento, lluvia, terremotos, sequías, etcétera); felizmente, la regularidad relativa como se manifestaban y las señales que se podían observar en el entorno que anunciaban la cercanía de un desastre (ciertas constelaciones, cometas, guanay que no baja a comer en el patio de Pachacamac, peces que saltan de las albercas, etcétera) les permitía organizar rogativas y ofrendas. Esta consideración nos llevó a revisar, aunque sea rápidamente, esa clase de acontecimientos en el área de la fiesta (25).

Las fuentes son distintas, pero tienen en común que proporcionan datos sobre repetidos eventos climáticos de cierta magnitud que, dada la forma de explotación agropecuaria de la época, tuvieron repercusiones sociales importantes.

La Encuesta de 1921 contiene noticias de que en 1840 hubo carestía cerca de la frontera de las provincias de Tucumán y Catamarca, es decir, en el valle de Yocavil y alrededores; otra poesía trataba sobre la carestía del año 1847.

Por su parte, V. Martin de Moussy decía que los veranos de 1847 y 1849 habían sido muy secos (1860: 382), y que en julio de 1858 se había sentido un temblor muy fuerte en la ciudad de Salta (1860: 192).

El año 1861 también fue recordado en poesías y relatos por un terremoto o temblor muy fuerte ocurrido en Mendoza y San Juan que se sintió en Tucumán, donde también hubo incendio de campos. Otra poesía hablaba sobre el temblor que se sintió en 1878 en Tucumán. Del año 1887 se recordaba una epidemia de cólera seguida por un levantamiento popular contra los gringos (italianos) que, decían, acaparaban los puestos de trabajo (Encuesta al Magisterio, 1921, carpetas correspondientes a Tucumán 3/88; 4/136; 6/217, 220, 225, 230, 235).

En 1894, un temblor derrumbó la iglesia de San Nicolás, catedral de la ciudad de La Rioja (Carrizo, 1942: lámina VIII), y el 4 de febrero de 1898 un temblor destruyó los pueblos de Huañumil, Pipanaco, Colpes, Joyango, Pisapanaco, Saujil, Malcascu, Mixango, Siján, Apuyacu, Pajango, Mutkin, Colana y Pomán, en la provincia de Catamarca (Lafone Quevedo, 1898: 265).

En el marco de las fenómenos climáticos ENSO (El Niño-Southern Oscillation) sabemos que los eventos medianamente registrados entre los años 1600 y 1614 fueron fuertes; en esa época el gobernador Alonso de Ribera escribía al rey la carta citada más arriba y los datos de la época fueron retomados también por el padre Lozano.

En 1692 se produjo el terremoto y desborde del río Salado (actual Juramento) que destruyó la ciudad de Esteco, durante un evento medianamente fuerte para el que se cuenta con buena información. La destrucción de la ciudad, que era una de las más prósperas del Tucumán, dio lugar a una leyenda que incluía una profecía de San Francisco Solano.

Entre 1835 y 1900, los ENSO de 1844-1846, 1876-1878 y 1899-1900, para los cuales se cuenta con información completa, fueron muy fuertes. El Niño de 1850, para el que también se cuenta con información completa, fue fuerte, al igual que el de 18541855; el de 1864 fue bastante fuerte al igual que el de 1867-1869 (Quinn, 1993: 17).

25 Para la costa norte del Perú y sur de Ecuador ver los trabajos de Huertas, 1993, Mabres et al., 1993. 
Otra comprobación de estos eventos puede consultarse en los resultados de los estudios de los bloques de hielo extraídos del nevado Quelccaya (sudeste del Cusco); en ellos fue posible reconocer la erupción del año 1600 y, según este registro, entre 1580 y 1880 aproximadamente, en los Andes tuvo lugar una pequeña edad de hielo (Thompson, 1993: 73).

Desde otro punto de vista, los relatos, poesías y noticias sobre eventos climáticos y su repercusión social entre 1840 y 1900 abarcaron la etapa de la historia nacional que comprendió, a grandes rasgos, las guerras entre los caudillos provinciales, la reorganización nacional, las migraciones de europeos hacia esta parte del continente americano y la conquista de los territorios pampeanos; también fue la época en que muchos hombres huían de las levas compulsivas del ejército y se iban a vivir entre los indios; de pueblos arrasados por los malones, de mujeres cautivas que formaban su familia en las tolderías, y de fronteras inciertas pero muy dinámicas, entre las tolderías y las ciudades (Barba, 1997; Mayo \& Latrubesse, 1993; Moreno, 1989; 1998; entre otros).

Fue la época en que surgió la creencia en la Difunta Correa, que murió de sed en el desierto cuando intentaba alcanzar la columna militar donde iba su esposo (Chertudi $\&$ Newbery, 1972), y las de los gauchos matreros pero milagreros (Coluccio, 1995), en tanto que de la catequesis resultaron los hallazgos de imágenes milagrosas, como de San José en un atadito de coca, en Jujuy (Colatarci, 1994).

A mediados del siglo XIX, cuando los grandes ingenios azucareros de Santiago del Estero y Tucumán alcanzaron su auge (Guy, 1981; Rosenzvaig \& Bonano, 1992), la creencia en El Familiar tomó la forma que le conocemos (Gentile, 1999a: capítulo 5). Y somos de la opinión de que en ese momento resurgió, o se manifestó más abiertamente como si hubiera estado disimulada, la creencia en El Chiqui, la suerte adversa andina a la que había que comprometer con una fiesta para que no lo fuera tanto.

Si bien se prohibió en 1859, (a partir de 1850 los ENSO fueron fuertes) todavía en el mapa publicado por Martin de Moussy, en base a datos recopilados alrededor de 1860, figura el sitio de Chiquiguasi muy cercano y hacia el sudeste de la ciudad de Catamarca, y es más que probable que ése fuera uno de los lugares donde se la llevaba a cabo.

Otra buena razón para prohibir la fiesta era que se la considerara un "remanente", que no concordaba con la fundación de la iglesia de Machigasta en 1852, además del progreso que significó la llegada del ferrocarril y el establecimiento de una estación en Aimogasta.

Es interesante en este contexto recordar la foto de la hija de Cativa, con quien conversara Carrizo en 1938, donde se la ve de pie, delante y a pocos metros del tocón quemado de lo que fuera el árbol del chiqui, que debe de haber sido corpulento, con un tronco de aproximadamente un metro de diámetro. A su alrededor no hay plantas, es decir, el monte ya se había consumido entre los durmientes para los rieles y las calderas de las locomotoras, en beneficio del transporte de minerales, algodón, ponchos, aguardiente y nueces.

4. También relacionado con este tema de la prohibición de la fiesta del chiqui estaba (aunque Carrizo no lo expresase en esos términos) la procesión y fiesta del "Señor de la Peña", que duraba desde "Viernes de Dolores hasta el Viernes Santo". 
El sitio era un abrigo bajo una roca en cuyo perfil exterior los devotos decían ver la imagen de Cristo; estaba a unos 30 kilómetros al sudeste de Aimogasta y en esa gruta

“... solía en otros tiempos, según la tradición conservada por habitantes ancianos de Aimogasta, servir de refugio a los cazadores de la comarca, que allí depositaban ofrendas a Llastay, el dios protector de los animales silvestres, y, al mismo tiempo, dios de la caza." (Boman, 1927-1932: 119).

Hoy día se llega al Señor de la Peña por una ruta asfaltada; el lugar convoca a miles de automovilistas que cómodamente se instalan a su alrededor (Néstor Kriscautzky, comunicación personal).

Sobre esto somos de la opinión que tanto El Chiqui como Llastay, fueron creencias prehispánicas con celebraciones dedicadas especialmente, y que un intento de suprimirlas fue quemando el árbol y, ante la imposibilidad física de destruir la gruta, le colocaron encima una cruz, y en la oquedad velas para que el humo cubriese cualquier pintura rupestre o petroglifo. Esto sucedió entre mediados y fines del siglo XIX, cuando la falta de agua era casi definitiva en la región (26), muchas chacras se habían perdido y la caza de guanacos era un recuerdo.

Entonces, si consideramos que la recolección de las vainas de algarroba y la rogativa por el agua de las chacras de maíziban juntos en el NOA se nota, aún en este rápido repaso, que hubo cierta relación entre la rogativa, por lugar y momento del año, la historia regional y algunos fenómenos climáticos adversos y recurrentes efectivamente ocurridos.

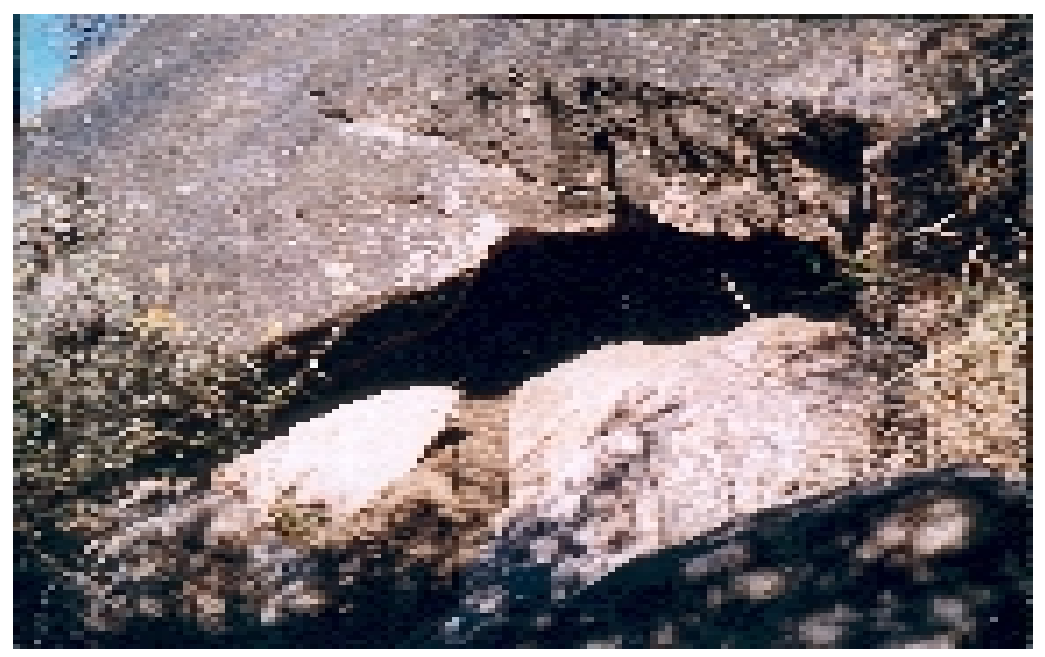

Fig. 36 - Entrada de la cueva llamada Salamanca de Santa Cruz, cerca de la ciudad de Catamarca, ubicada casi en el sitio que V.Martin de Moussy llamaba Chiquiguasi. Es un sitio lóbrego, con corrientes de aire internas. Actualmente se realizan allí rituales de magia negra. Foto y datos cortesía de los Doctores Néstor Kriscautzky y Enrique Nogués, Universidad Nacional de Catamarca.

(26) En algunos lugares, el ferrocarril llevaba agua para la gente que vivía allí. 


\section{3. Un poco más sobre la música andina}

Este es un asunto que rara vez mereció atención en los documentos coloniales o en los relatos regionales, tal vez porque el concepto de "música" era europeo y estaba asociado al sonido de determinados instrumentos que debían hacerlo según ciertas pautas.

El indio Peralta no mencionaba los instrumentos musicales con que se acompañaba "el canto o vidala de los indios" para conjurar "la mala suerte en tiempo de seca ú otra calamidad", pero una de las versiones recogida en la Encuesta decía que en Antinaco "Danzaban alrededor del arbol, entonando cánticos y vidalitas, acompañados con tambores." (27).

Recordemos también los vasos silbadores y un bastón de ritmo preincaicos, todos con representaciones de loros, que sugieren un acompañamiento musical y alguna relación con estas aves, aunque todavía no sepamos cómo se desarrolló la ceremonia que acompañaban (Fig. 37, 38, 39, 40).

En el Cusco incaico se realizaban durante el mes de octubre procesiones acompañadas con lamentos para rogar por la lluvia (Guamán Poma, 1980[1613]: 129). En esta figura no se ven instrumentos musicales, de manera que el canto triste y la rogativa en sí serían los únicos puntos en común con la fiesta de El Chiqui; pero con relación a ésta y las de Cochabamba y Potosí (donde también se rogaba por el agua para las chacras y se comprometía a los difuntos) se usaban cajas, tal vez para marcar el paso de la marcha e indicar los giros (28).

En el siglo XVII,

"Huacayllicuni. Era inocuar [sic por inuocar] a Dios llorando por agua cantando de noche por las calles vn cantar lloroso. Huacaylli. Era la inuocación que hazían a Dios por agua lluuia quando no llouia. Huacayllicuy. La procesión, o qualquiera inuocacion que se haga por agua que assi lo vsan agora los indios en la falta de agua Dios hazedor del hombre danos tu agua y los tonos son ayau queu, sol, fa, mi, a Nuestra Señora Ayau hiau parayquicta cachamuy queu queu que mama, Ayaya runay rurak vnuyquicta cachamuy \&c." (Gonçalez Holguin, 1952[1608]: 167; lo resaltado es nuestro).

Es decir, se trata de una rogativa prehispánica en su nueva versión cristiana en cuanto a la letra pero ¿habrá continuado la misma música?

Consultamos con Rubén Pérez Bugallo la posibilidad de poner música a la vidala recopilada en 1886 en el Valle Vicioso por el padre Vázquez, pero este etnomusicólogo nos aseguró que no era posible adaptar ese texto a una especie musical como la de la

(27) Tampoco sabemos si los instrumentos musicales que se usaban en ese momento en la regíon se podían nombrar fuera de ciertos contextos, o algo así, porque algunos de ellos solamente se pueden tañer en determinada época del año o bajo ciertas circunstancias, para no desdencadenar tempestades o atraer el viento, por ejemplo.

(28) En Cochabamba, en 1784, la música que la acompañaba era descrita como "bulla" por los españoles (Gentile, 1994; 1999c). A la misma ceremonia, en Potosí, la gente iba “... al toque de cajas, con numeroso acompañamiento de hombres y mujeres de la misma casta. Encienden sus luces y pasan todo el día y la noche en grandes lamentaciones ..., y a medida que los doloridos van aumentando su embriaguez crece el exceso de los alaridos ... ." (Cañete y Dominguez, 1952[1791]: 298-299). 


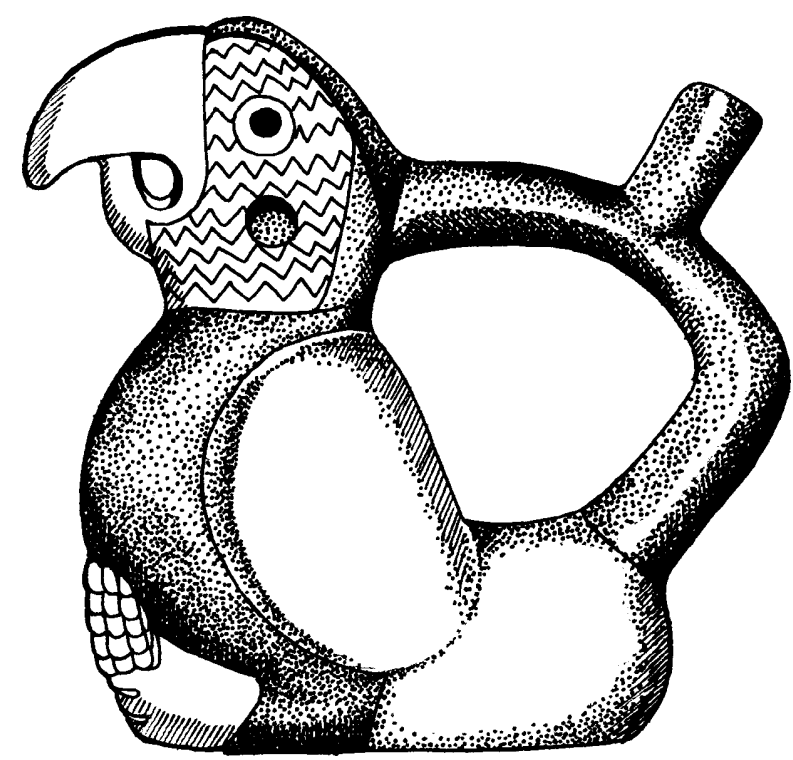

Fig. 37 - "Ara severa que coge con las patas un choclo" (Dibujo de Susana Albarello según Tello, 1938: 155). Se trata de una vasija silbato.

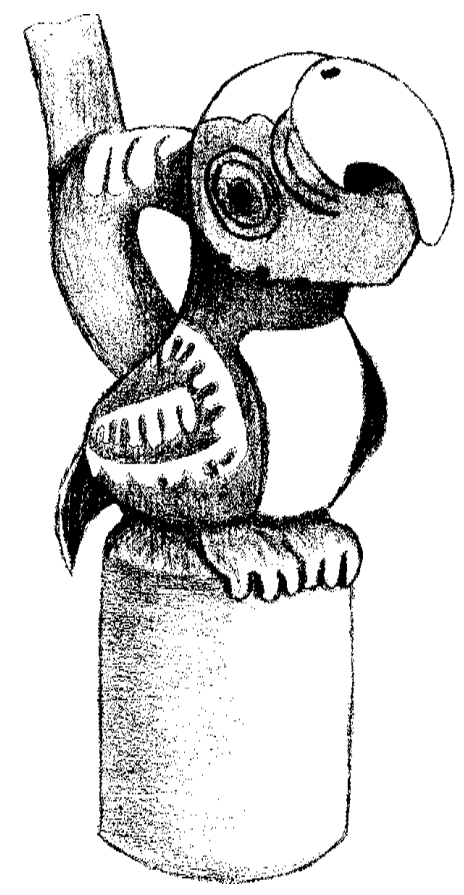

Fig. 38 - “Loro. Vasija silbato. Vicús.” (dibujo de MG según Lumbreras, 1978: figura 71). Las plumas están pintadas en blanco sobre el color de la terracota. 


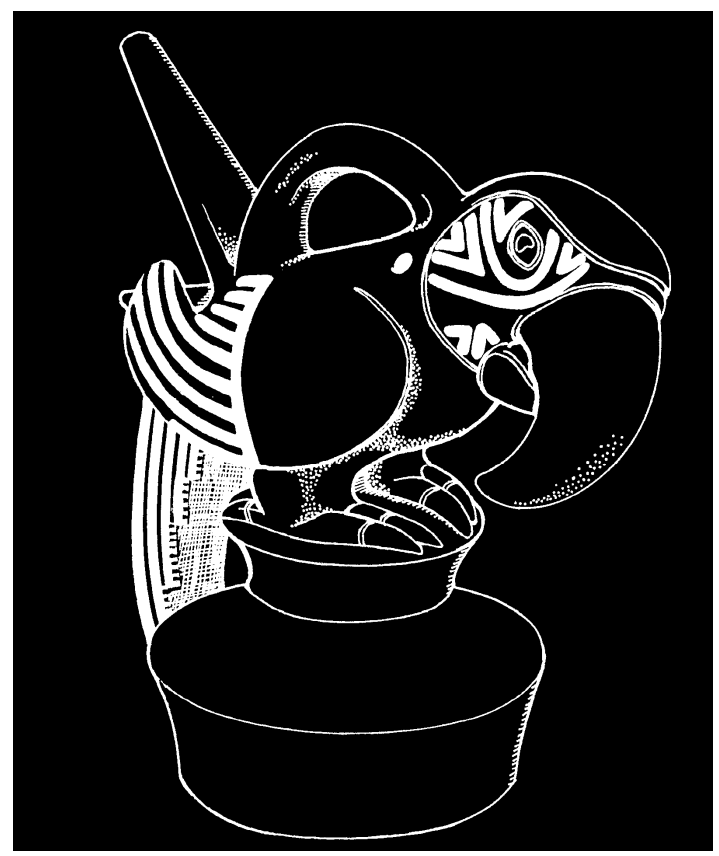

Fig. 39 - Vasija silbato. "Papagayo. Vicús. Virú.” (dibujo de Susana Albarello según Lumbreras, 1978: figura 72). Las plumas están pintadas en color blanco sobre la terracota.

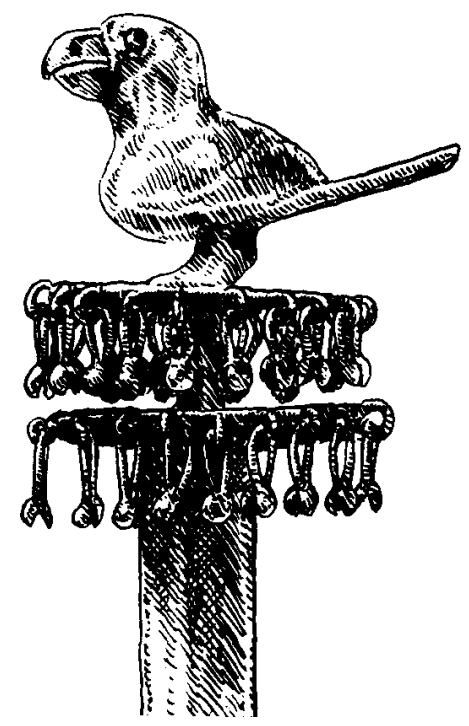

Fig. 40 - Bastón de ritmo con sonajero colgante, metal, estilo Inca-Chimú, procedente de Perú. Museo Chileno de Arte Precolombino, exposición "La música en el arte precolombino", 1982. 
vidala. Le sugerimos que podría ser una chaya riojana, pero nos explicó que esa especie databa de 1940.

En 1938, Carrizo no hizo ninguna referencia ni a la música ni a los instrumentos musicales usados durante la fiesta de El Chiqui, pero en el dibujo que acompañaba su texto se ven dos músicos (caja y quena) y un cantor.

\section{4. Los loros como forma de chiqui}

1. El Chiqui del noroeste argentino no tenía un aspecto físico exclusivo, ni era lo contrario de Pucllay o Pacha Mama, como hubiera querido Quiroga; ni era vengativo, ni originario del NOA como decía Ambrosetti, y hasta parece que era preincaico, a pesar de Boman.

Pero sí era posible representar cosas que evocaran en quien las viera o escuchara una situación chiqui, o partes de la ceremonia llevada a cabo para congraciar a la suerte adversa.

Algunos de los aspectos prehispánicos de la fiesta pueden verse, por ejemplo, en la costa norte del Perú. Las carreras, las cacerías de venados, los juegos, las luchas y las gentes arrojadas desde las terrazas de un templo, modelados o dibujados en los huacos vicús y mochica; la suerte adversa tenía en esa región la forma (entre otras) de catástrofes climáticas y podría haber sido congraciada con ofrendas como las descubiertas por Steve Bourget en la Huaca de la Luna (1998). La alfarería de Nasca también tiene algunos temas que podrían relacionarse con ceremonias similares, como las orlas de cabezas ceremoniales en los ипси de los guerreros o los postes con cabezas expuestas (Gentile, 1974).

En el Cusco incaico se ofrecía la capacocha en Chiquinapampa para rogar que no sucediesen desgracias. En el NOA, si bien tenemos varios topónimos que incluyen el morfo chiqui, ninguno de ellos, hasta donde sabemos, estuvo relacionado con entierros que hubieran sido claramente ofrendas, sino más bien con una topografía que resistía al asentamiento humano.

Sin embargo, los entierros prehispánicos de niños en urnas, de los cuales hubo muchos en el área de los diaguitas (29), podrían haber sido también parte de las ceremonias para pedir agua para el maíz, alejar a los loros de las chacras, o alguna otra calamidad, es decir, una capacocha.

Éste habría sido el tramo reemplazado durante la colonia española: la ofrenda humana se habría cambiado por muñecos de masa colgados de un árbol, gesto que, por otra parte, tiene antecedentes europeos medievales referidos a los productos de la caza (de la Vorágine, 1987[c.1264], I: 423); a veces se traba de confituras o quesillos, que debían ser alcanzados hamacándose muy alto en un columpio, interpretándose que se sacaban almas del Purgatorio por cada premio obtenido.

Por otra parte, a Boman le llamó la atención la cantidad de fragmentos de grandes pipas de cerámica hallados en sitios de La Rioja entre las urnas de párvulos, ¿se fumaba en el lugar como parte de alguna ceremonia? ¿cuándo? ¿antes, durante, o después del entierro?

(29) Vignati (1953) trae noticias sobre un entierro de este tipo realizado en La Rioja, en tiempos de San Francisco Solano, pero el texto es confuso y se abre a otras conjeturas, por ejemplo, que hubiera sido una ceremonia realizada en el sitio de un entierro anterior. 
2. Chiqui eran también los loros que en bandadas destruían los maizales; por eso buscamos su representación. De todas las situaciones de desgracia, ellos fueron sobre los que conseguimos datos con más facilidad, y eso también nos indica, por si hiciera falta recordarlo, acerca de la importancia del maíz en la dieta andina. Además, hasta donde sabemos, ningún otro animal cuenta con un registro arqueológico y documental tan claro sobre lo poco deseable que era su presencia a la que, sin embargo, como chiqui, había que congraciar (Fig. 41-47).

Por ser una figura nada emblemática, la del loro casi no fue reconocida en los estudios del arte prehispánico donde las aves siempre parecían ser rapaces (cóndores, halcones o águilas) según las pautas de la heráldica; o el picaflor, que era bonito; y últimamente se reconoce al guanay (¿por la utilidad del guano?); en último caso, las aves sólo eran figuras ornitomorfas.

En todas las culturas andinas prehispánicas hubo representaciones de loros, y hasta parece que hubo un templo donde la divinidad y el edificio tenían su forma (30). Y como oráculos, sus dichos eran poco agradables.

En las piezas prehispánicas más realistas los loros sostienen mazorcas entre las patas, están trepados a la planta o parados en la punta de un poste. Se los reconoce por su pico recio y curvo, la cabeza redonda y grande, las marcas que le rodean los ojos, y las patas fuertes (Narosky \& Yzurieta, 1993: 34).

A veces, el maíz está representado por un diseño más estilizado como el del cassana uncu, cuadriculado en blanco y negro, presente en Nasca, Moche (Gentile, 1996; 1999c) y en el cuerpo de los loros de un puco estilo Hualfín.

En cambio, en la pintura rupestre de Quillarumi, en uno de los tiestos de alfarería incaica hallada en los alrededores del Cusco y en la placa de Tolombón, el maíz estaría representado por círculos con punto interior, o dos semicírculos que no llegaban a juntarse, también con un punto interior; las ondas, en estos casos, representarían el agua.

Los artistas y artesanos andinos prehispánicos captaron a los loros en sus actitudes características siendo la más impresionante la del ave abatiéndose sobre el maizal. O sosteniendo una mazorca entre las patas, en actitud de comer, o trepado a la planta. Probablemente hubieron loros domésticos y esos serían los que estaban parados en la punta de un poste o en el hombro de las personas, como se puede ver en un grupo familiar de Nasca que, además van acompañados de perritos (Tello, 1931).

En algunos casos se ve que los loros están volando, como en la pintura rupestre de Quillarumi,oenelvasoprocendentedeLaPuerta(Catamarca). Tambiénenlas representaciones de loros y tigres, las aves están en el aire formando parte de una escena donde algo está sucediendo relacionado con un relato que todavía no conocemos (Fig. 48, 49).

En cuanto a los loros que acompañan al personaje en una de las placas de metal, su ubicación en los hombros y mirándolo sugiere que le hablan (¿oráculo?) y el otro escucha, pero en la placa de Tolombón están como trepando por el costado del personaje, en tanto que los tigres están en el hombro.

(30) ¿Tal vez la planta del edificio tuvo esa forma, como se dice que la planta del Cusco semejaba un puma? La ubicación en terreno de ese templo sería un aporte interesante. 


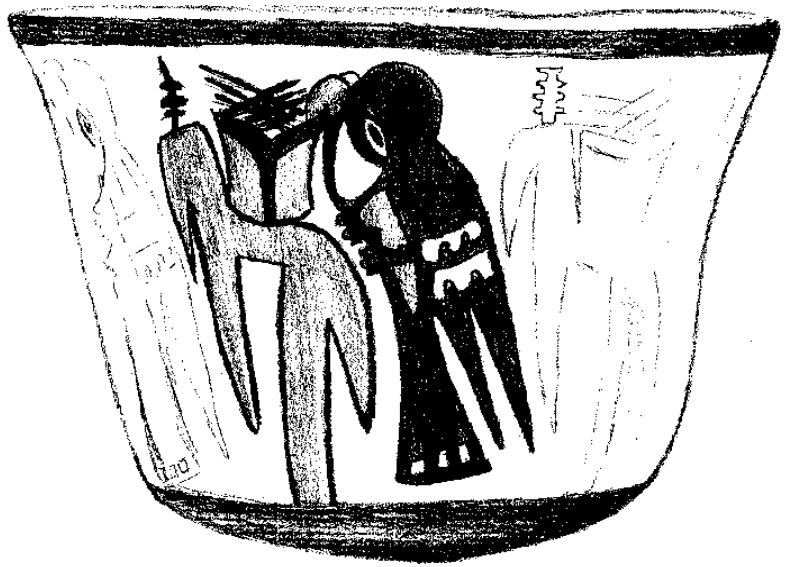

Fig. 41 - Loros en un maizal. Vasija estilo Nasca, de unos $10 \mathrm{~cm}$. de diámetro, colección particular, Lima. Dibujo MG.

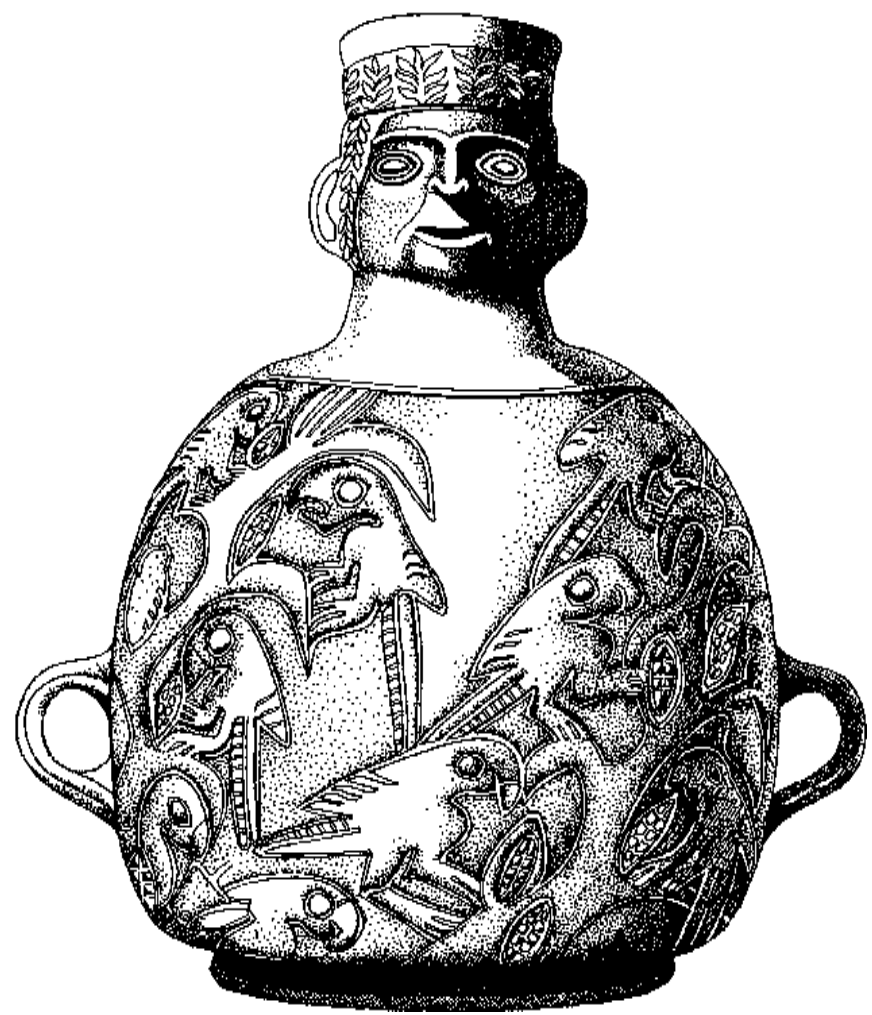

Fig. 42 - Aribaloide de asas asimétricas, Museo Amano, Lima, $\mathrm{N}^{\circ} 0122$. La pieza es de color negro y tiene en relieve loros en un maizal. Dibujo de Susana Albarello. 


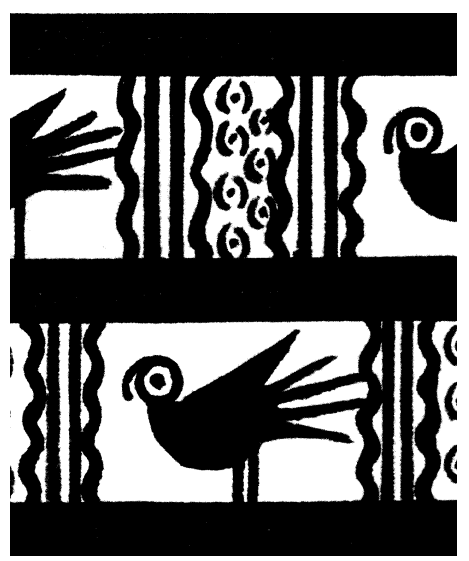

Fig. 43 - Alfarería incaica. 'Loros denominados 'huacamayos', en espacios intercalados con figuras geométricas ...” (según Fernández Baca Cosio, 1989: figura 205).

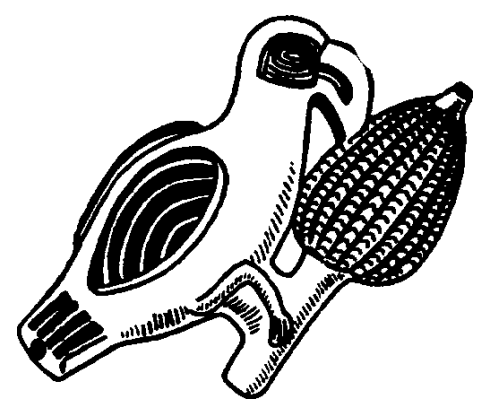

Fig. 44 - Paccha chimú usada en ceremonias relacionadas con la agricultura (según Carrión, 1955: lámina XXI, l - ll). Representa un loro trepado en la planta, comiendo maíz.

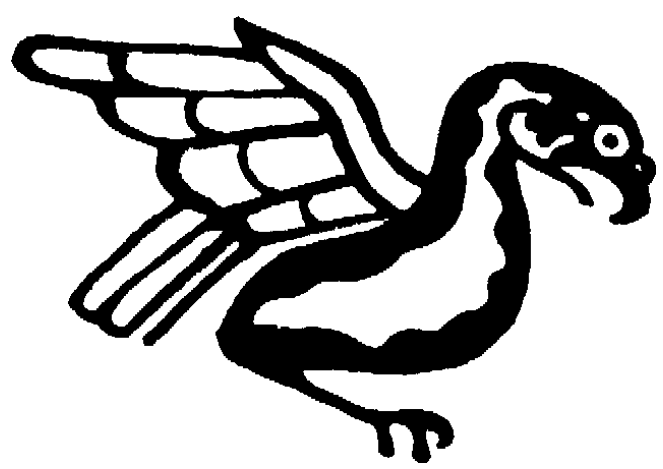

Fig. 45 - Loro abatiéndose sobre un maizal, dibujo sobre alfarería mochica, colección particular, Lima. 


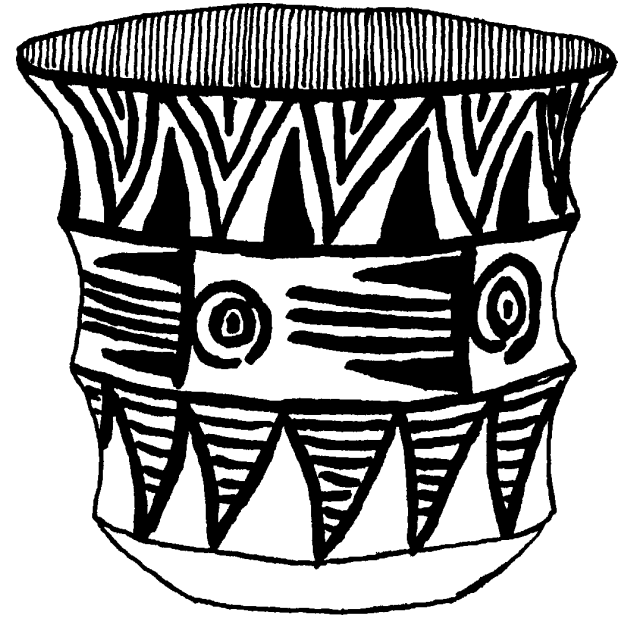

Fig. 46 - Vaso color rojo amarillento procedente de La Puerta (Catamarca), de $14 \mathrm{~cm}$. de altura y 13 de diámetro. La franja central está finamente pulida y en ella están dibujados cinco loros (Debenedetti, carpeta I: 34; según Bregante, 1926:

figura 121). Colección Uhle, Museo Etnográfico de Berlín Vc. 1639.
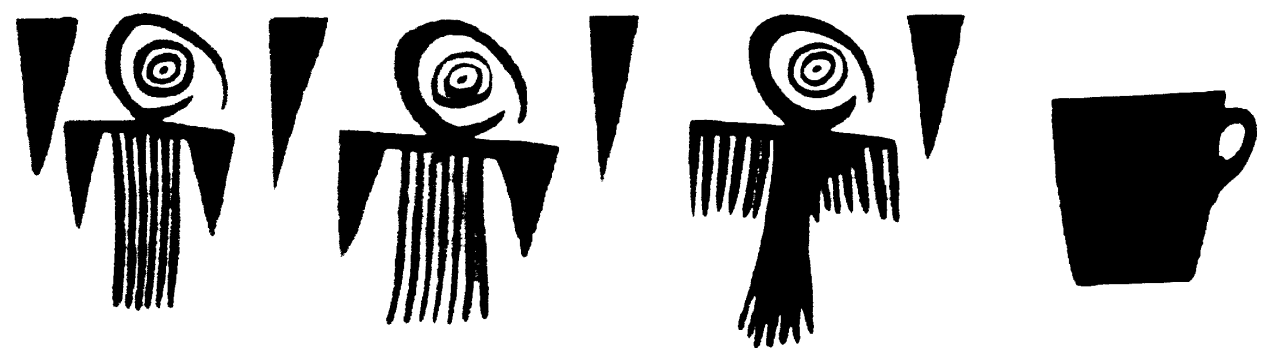

Fig. 47 - Figuras muy estilizadas, de loros, formando guarda en un jarro estilo Hualfín pintado. Colección B. Muñiz Barreto, Museo de La Plata, No 12751 (según González \& Montes, 1998: XXI-6).

Como partes de un todo, parece que las plumas también tuvieron importancia. Por ejemplo, el niño ofrecido en capacocha en el cerro Aconcagua tenía en la cabeza un penacho de plumas de tucán, otro goloso del maíz, y las plumas del manto que envolvían su fardo eran de guacamayo (Fig. 50). Aparte de la elección de las plumas por el significado de sus colores en el contexto de la ofrenda, recordemos que la figurita de mullu que lo acompañaba vestía el uncu cuadriculado del guerrero, tal vez un conquistador de tierras para cultivo de maíz (Gentile, 1996b, 1999c). También el niño enterrado en un montículo artificial rematado por una huanca, en El Pichao, valle de Yocavil (Tartusi \& Núñez Regueiro, 1993) estaba dentro de una urna que representaba otro personaje vestido con el cassana uncu (Gentile, 1996b; 1999c). 


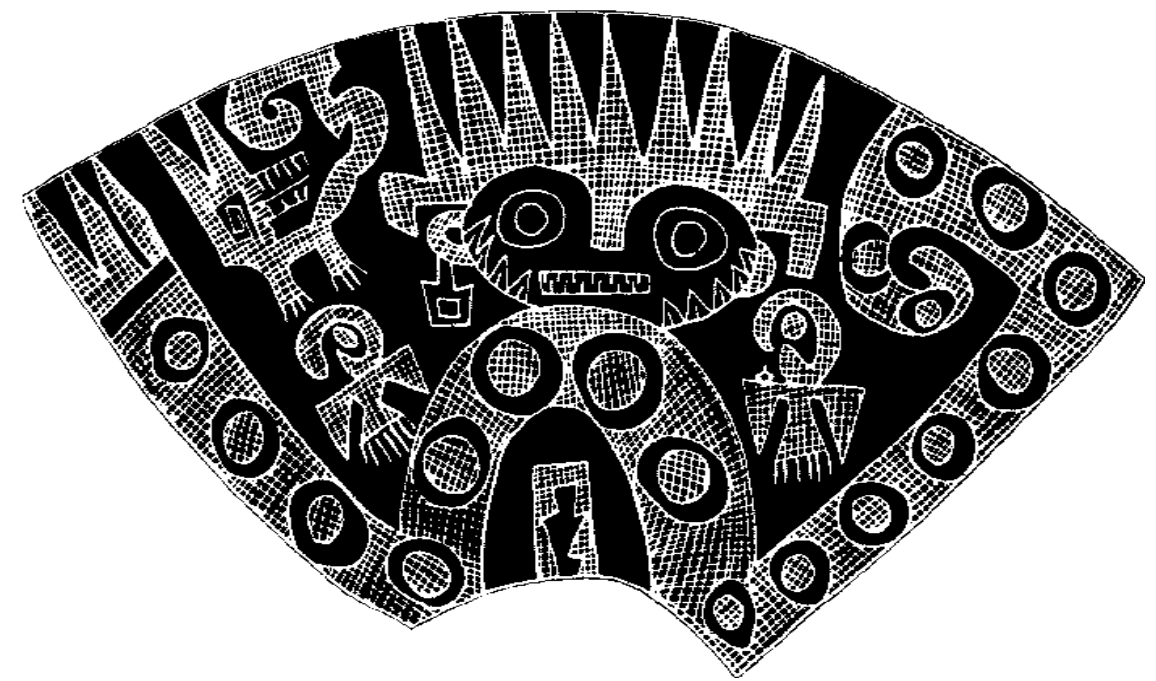

Fig. 48 - Antropomorfo felinizado, felino y loros, grabados en un puco negro, cultura de La Aguada. Colección B. Muñiz Barreto, Museo de La Plata No 12831 (según González \& Montes, 1998: IV).

\section{5. El Chiqui, Pucllay y Pacha Mama}

Vimos antes cómo El Chiqui y Llastay compartieron un mismo destino basado en cambios sociales y del medio ambiente, en una región con muy pocas posibilidades de revertir a su favor ninguno de estos acontecimientos.

Acerca de las divinidades locales, Quiroga decía que El Chiqui era "el reverso de Pucllay y Pacha Mama" (1897: 550), es decir “alegre, festivo y risueño" el primero (p. 558) y protectora la segunda, cuyo culto era el "culto a la Tierra" (p. 567). También consideraba que "Llastay y Pacha Mama parecen gemelos en la tradición religiosa de los calchaquíes... siendo Llastay el genio protector masculino, y Pacha Mama, femenina." (p. 565). Y en cuanto a El Chiqui, era "el numen funesto" (p. 550) pero al mismo tiempo había que "implorarle... para que la cosecha fuera pingüe".

En su entusiasmado propósito de definirlo, Quiroga no se ahorró adjudicarle a $E l$ Chiqui rasgos que amalgamaban los de otros númenes andinos, resultando así una mezcla de caracteres diversos que se manifestaba cuando trataba de definir a la siguiente divinidad de la lista. Luego las comparó con sus correspondientes en las "religiones primitivas".

De esta manera se fue quedando en el camino la posibilidad de discernir las originalidades, como en cualquier trabajo sobre las creencias andinas locales, que busque explicarlas en términos de la mitología greco-latina, o de cualquier otra.

Entre estas originalidades tenemos que los niños, cuyos restos se encontraban en las urnas, se convertían en genios tutelares que protegían del Chiqui a su comunidad; que las campanas y discos de bronce servían para el culto del Chiqui, es decir, de la lluvia; y que Pacha Mama era una deidad de la mitología calchaquí más moderna que El Chiqui, 


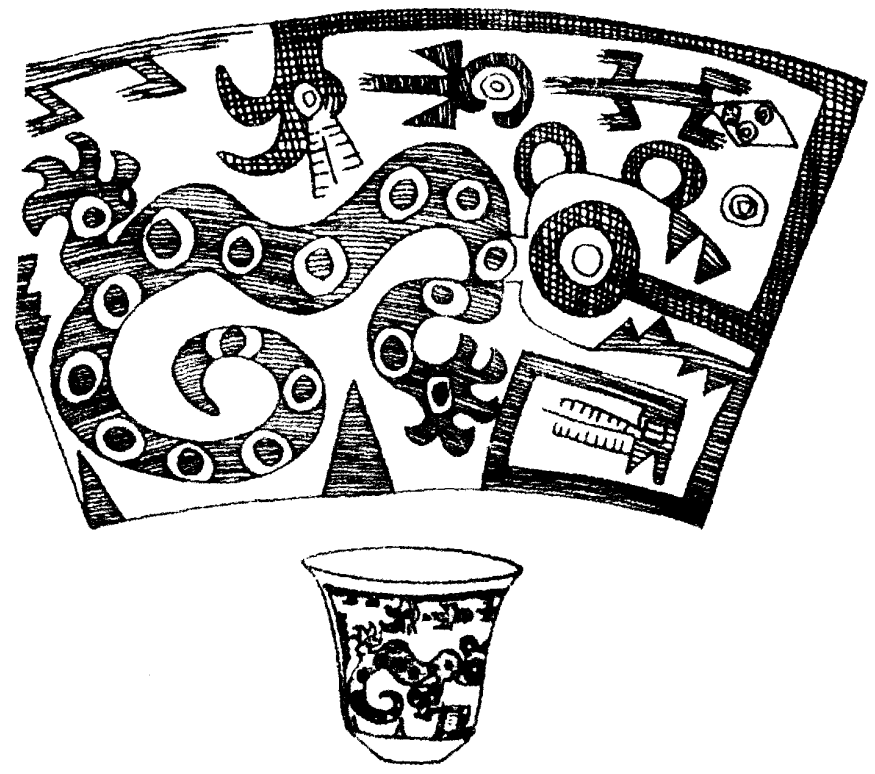

Fig. 49 - Escena de la selva con un felino, un loro y ¿una lagartija? entre otros animales (según González \& Montes, 1998: lámina XI 1).

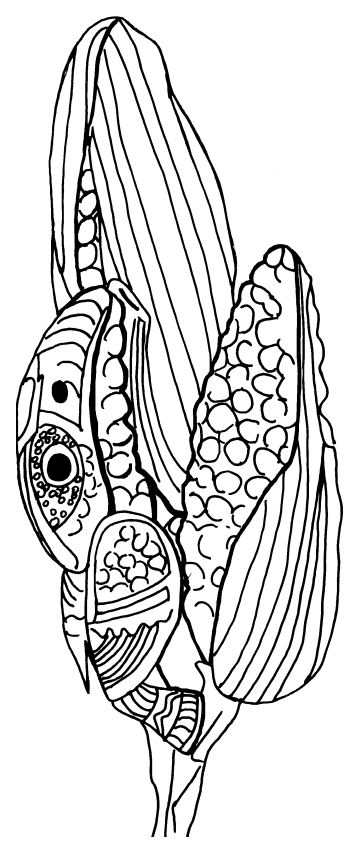

Fig. 50 - Tucán trepado en una planta de maíz, comiendo. Figura realizada con láminas de plata repujadas, cultura Vicús (dibujo de Fátima Hatano según Catálogo de la exposición "El maíz en la cultura peruana, Banco Continental, 1994). 
tal vez un desdoblamiento de él, o importada desde otra parte. Por su parte, El Chiqui no solamente era más antiguo que Pacha Mama sino que, además, era originario del NOA (Ambrosetti, 1899: 154-156).

En nuestra opinión, aquí no se trataba solamente de que si El Chiqui tenía, o no, una figura determinada, o un carácter determinado, sino que se trata de interpretar, en este caso la fiesta y el juego del chiqui, a partir de lo aprehendido de una conversación mediante intérprete, o la lectura de párrafos descontextuados acerca de una idea inexpresable en términos no-andinos, y creer buenamente que cualquier hueco en los datos obtenidos podía ser rellenado, sin faltar a nada, con otros datos lejanos en espacio y tiempo, de acuerdo con un esquema prefijado en los siglos anteriores en Europa, cuando se retornó al ideal de vida greco-latino como respuesta a la austeridad medieval.

Este manejo de los datos hubiera requerido muchas más precauciones que las desplegadas por nuestros autores, quienes, sin embargo, trabajaron de acuerdo con una metodología que en esa época se consideraba adecuada.

\section{6. Un poco más sobre la religión prehispánica y sus pervivencias}

1. El maíz fue, junto con la papa, la base de la alimentación andina y se dedicó tanto esfuerzo a la construcción de andenes de cultivo, canales, cochas y colcas como a tratar de propiciar a las divinidades relacionadas con las buenas cosechas (Carrión Cachot, 1959; Soldi, 1980, entre otros).

Con relación al maíz, parece verosímil que las representaciones prehispánicas de loros estuvieron relacionadas con ceremonias, tal vez diferentes según la época y el lugar, pero todas ellas destinadas a tratar de alejarlos de las chacras, o por lo menos disminuir el daño que su invasión producía.

Los bastones de ritmo chimú y los vasos silbadores mochica o vicús, indicarían algún tipo de acompañamiento musical, en tanto que las manoplas servirían en combates mágicos como parte de un conjuro.

Y, según Lozano (1970[1754]: 425), los caylles o "imágenes labradas en láminas de cobre", serían amuletos para alejar la piedra, la langosta y las pestes de los sembrados y esa habría sido la función de las placas metálicas como las de Tolombón y Riberalta, porque caylles (31) tal vez estuviera relacionado con huacayllicuni, que era invocar a Dios, cantando de noche por las calles un cantar lloroso llamado huacaylli, pidiendo lluvia; y huacayllicuy era la procesión o cualquier invocación para pedir agua (Gonçalez Holguin, 1952[1608]: 167). ¿Se llevarían los caylles durante las procesiones?

Esta voz quechua nos remite nuevamente a los callchac del valle Calchaquí, y agregaría otra certeza a la de que eran agricultores de maíz porque los caylles, también según Lozano, los usaban los indios que vivían dentro de dicho valle.

2. Pero, durante nuestra recopilación de testamentos de indios del área andina argentina encontramos una referencia del siglo XVIII que podría retrotraernos a los caylles del siglo XVI. Se trata del testamento de Theresa, una india pobre que vivía en la ciudad de Mendoza. Sus bienes no dejan dudas sobre su situación económica, pero

(31) Caylles sería el plural "españolizado" de caylle. 
es notable que este testamento sea el único redactado en papel sellado (y arancelado) que encontramos hasta ahora. Entre otros, decía que "Ytt. declaro por vienes mios seyz estampas de papel viejas y mas ventiquatro pequeñitas viejas".

Estas "estampas" están a continuación de una "ymagensita de yezo de bulto que hesta en su cajonsito", y son parte de lo que llamamos "grupo de bienes relacionados con la religión" de este testamento. Este grupo de bienes, en general, se encuentra luego de los muebles de la casa y antes de los de la cocina (AH-M, fs.12-13v).

La importancia de estas estampas viejas probablemente esté dada por su función, es decir, de proteger a su propietaria, al igual que los caylles parecían hacerlo. Frente a ellas se haría oración, se rogaría, se lloraría, se las llevaría consigo.

Morfológicamente deben de haber sido similares en tamaño, pero diferentes en soporte, como corresponde a productos de dos épocas diferentes.

3. Un dibujo de Guamán Poma mostraba unos muchachos ahuyentando a loros y otros animales de la chacra, y explicaba el cronista que en esta tarea se turnaban día y noche hasta que terminaba la cosecha del maíz.

Esta imagen nos regresa a la vidala riojana del siglo XIX: en el verano, el presagio de que continuarían el calor y la sequía, era ver al mediodía levantarse el viento formando remolinos de color naranja-rojizo, a los que una lluvia en gruesas gotas asentaba de a poco, durante la tarde, dejando ver por un largo rato una franja superior de paisaje despejado y por debajo de ella la tierra rojiza todavía en suspensión (32).

En nuestra opinión, el texto publicado por Lafone, pero en la traducción del maestro de Susques, describía la preocupación de la gente cuando se acercaba la sazón del maíz. Y cómo un grupo de jinetes salía de noche a ahuyentar a los depredadores, comunicándose con silbidos mientras cazaban liebres y guanacos, tanto para probar su vigilancia como para resarcirse de la vela con un buen asado en la madrugada.

Este recorrido nocturno, que tenía su contraparte diurna, estuvo relacionado en época prehispánica también con el cuidado de los cultivos de maíz, allí o en otra parte de los Andes.

4. Una de las señoras que le contara a Carrizo cómo era la fiesta del chiqui a fines del siglo XIX, decía que las cabezas de animales que se usaban podían ser secas o frescas, entonces ¿se guardaban las cabezas de un año para otro y la cacería no tenía, en ese momento, la importancia de años atrás, lo mismo que la ronda nocturna? ¿o no era tan fácil salir a cazar guanacos y liebres, y regresar en solamente una noche con varias piezas?

Agregaba también la señora que la fiesta se hacía el domingo, lunes y martes de Carnaval (igual que en el árbol de Antinaco, versión 1), lo que permite suponer que, ante la dificultad de llevarla a cabo cuando la gente estaba en la recolección de la algarroba, o en cualquier momento del año que se precisara conjurar una desgracia, se la disimuló bajo la forma de ese "divertimiento de Carnaval".

(32) Observación personal. Esta imagen nos remite a las dos franjas, amarillenta y roja, superior e inferior, que tienen algunas vasijas antropomorfas del período incaico del NOA, cuyas asas asimétricas son los brazos y en el gollete a veces tienen un rostro en relieve, relacionadas con pedidos de agua (Gentile, 1991). Es probable que las ondas hayan estado relacionadas con el agua y las espirales con el viento. También la fiesta del Chiqui consistía en hacer como una ronda alrededor del árbol. 
5. Llegados a este punto debemos preguntarnos si acaso no se superpondría la fiesta del chiqui con la de Pucllay, el Carnaval por excelencia en el NOA. Esta incongruencia, no llamó la atención de Carrizo, ni de Quiroga. A nuestro entender, la misma deja en claro los distintos niveles de discursos que merecerían otra atención, como señalamos antes con relación al relato del indio Peralta.

A nuestro entender, la fiesta y el juego de El Chiqui estuvieron relacionados más con las plantas de maíz que estaban creciendo y para que no les falte agua oportuna, que con la recolección de la algarroba, aunque era necesario el calor del verano y el canto del coyuyo, una especie de cigarra muy grande y ruidosa, para que maduren las vainas para hacer aloja, patay y la fiesta.

La cacería de animales salvajes, el baile, el canto, la competencia, los brindis reflejaban la pervivencia de una forma andina prehispánica de comprometer a la suerte adversa para que no castigue tanto.

La realización de esta ceremonia en los sitios prehispánicos con cultivos de maíz se puede suponer que data del momento de expansión incaica, aunque las representaciones de loros en piezas preincaicas nos permiten decir que aquí se habían implementado otras "técnicas", tal vez relacionados con el pilla-jacica y las placas de metal.

\section{7. Sobre algunos animales domésticos andinos}

1. Si las representaciones de loros, sobre cualquier soporte, estuvieron relacionadas con ceremonias para alejarlos o por lo menos reducir su accionar (las cantidades de chicha ofrecidas en el templo de Paucar era para que, habiendo gustado de lo mejor, ¿no atacasen los cultivos?), se podría suponer que otros animales también podrían encontrarse en una situación similar. En este punto, el criterio europeo para definir cuál era, o no, un animal doméstico, no podría aplicarse.

Sobre el suri, más allá de las interpretaciones de Lafone, Quiroga y Ambrosetti acerca del carácter de animal sagrado relacionado con la nube y la lluvia, lo ubicamos dentro del grupo de los animales domésticos criados con el fin de utilizar sus plumas o como compañero en los arreos; por eso su cabeza no estaba entre las que acompañaban la fiesta de El Chiqui.

Desde esta perspectiva, el significado de los dibujos de suri en las urnas del valle de Yocavil podría ser reconsiderado tomando en cuenta que algunas de estas aves tienen dentro de su cuerpo figurados escaques, estilización del maíz; o el personaje bifronte representado por la misma urna tiene escaques blancos y negros en su ropa, como los guerreros que conquistaban nuevas tierras para cultivo, porque esta alfarería estaba relacionada con la expansión imperial incaica hacia el actual noroeste argentino, evidente ya en tiempos de Cápac Yupanqui, continuada por Topa Inga y consolidada por Huayna Capac (Gentile, 1992).

2. Unas palabras más sobre los animales domésticos andinos. En Palo Blanco se encontró un loro retenido en cautiverio, no sabemos si para usar sus plumas, como oráculo, o qué. Murúa decía que la coya Ipaguaco criaba aves por sus plumas (Murúa, 1946[1600]: 94).

También otros animales considerados no domésticos por los europeos, como tigres y boas, fueron criados en las casas en algunas épocas y regiones andinas. Por 
ejemplo, se ve en algunas piezas mochica a un personaje lujosamente ataviado, sentado en un trono y puesta su mano sobre la cabeza de un puma (Benson, 1972: figura 2-10); en una pieza Aguada, dos jaguares atados a un palenque tienen los dientes redondeados y carecen de garras (González \& Montes, 1998: figura 229, inferior); en los relatos de Huarochirí el puma rojo era un aliado de Huatyacuri (Ávila, 1966: 41).

Como animales domésticos poco convencionales, para llamarlos de alguna manera, nos parecen dignos de atención, porque su presencia en determinados contextos puede ayudar a comprender algunas interracciones en la vida andina.

Además, es probable que el tema está vigente en algunos lugares: en 1979 vimos una llama guachita en una casa en la puna de Jujuy donde, apenas llegamos el dueño nos advirtió de no acercarnos ni tocarla, ya que mordía a los desconocidos porque "es como un perro", es decir, un guardián fiel. Por otra parte, hay relatos acerca del suri que transitan la misma línea. En 1998, en la provincia de San Luis, una persona nos explicó que alguna gente criaba unas culebras negras y grandes en las casas de campo porque comían a los ratones.

\section{8. A modo de palabras finales}

En este ensayo tratamos de acercarnos lo más posible a materiales arqueológicos y documentales andinos; reunimos en la discusión datos importantes y novedosos, no obstante lo cual quedaron abiertas preguntas y temas (la yunza, entre otros). De todos modos, la suerte adversa andina, sus representaciones y las ceremonias destinadas a congraciarla se encuentran hoy en mejor situación de ser estudiadas y comparadas a como estaban hace cien años porque lo que por un tiempo se pensó que era un sistema de creencias propio de los Andes centrales encontró ahora un nuevo borde, mucho más al sur, en la región del noroeste argentino, acompañado por una cronología más temprana.

\section{Referencias citadas}

AGÜERO VERA, J. Z., 1972[s/f] - Divinidades diaguitas, 226p.; Tucumán: Universidad Nacional de Tucumán, Facultad de Filosofía y Letras.

AGUSTINOS, Religiosos, 1992[c.1560] - Relación de la religión y ritos del Perú hecha por los padres agustinos, XCI + 74p.; Lima: Fondo Editorial, Pontificia Universidad Católica del Perú. Edición, estudio preliminar y notas de Lucila Castro de Trelles

AH-M - ARCHIVO HISTÓRICO DE MENDOZA, 1721 - Protocolo 37, año 1721.

AMBROSETTI, J. B., 1899 - Notas de arqueología calchaquí: Fetiches animales. Boletín del Instituto Geográfico Americano, XX: 253-302; Buenos Aires.

AMBROSETTI, J. B., 1904 - El bronce en la región Calchaquí. Anales del Museo Nacional de Buenos Aires, XI:163-314; Buenos Aires.

AMBROSETTI, J. B., 1967[1917] - Supersticiones y leyendas. Región misionera, valles Calchaquíes y las pampas, 259p.; Santa Fé: Librería y Editorial Castellví. 
ANB - ARCHIVO NACIONAL DE BOLIVIA, EC 1694, N 27, 1694 - Visita de Santiago del Estero practicada por Don Antonio Martínez Luján de Vargas, el oidor más antiguo de la Real Audiencia de La Plata: 301 fs.

ANELlo OLIVA, G., 1998[1631] - Historia del reino y provincias del Perú y vidas de los varones insignes de la Compañía de Jesús, 386p.; Lima: Pontificia Universidad Católica del Perú. Edición, prólogo y notas de Carlos M. Gálvez Peña.

ANÓNIMO (Alonso de Barzana?), 1951[1586] - Vocabulario y phrasis en la lengua general de los indios del Perú llamada quichua y en la lengua española, 222p.; Lima: Universidad Nacional Mayor de San Marcos.

ARRIAGA, P. J. de, 1968[1621] - La extirpación de la idolatría en el Perú. In: Biblioteca de Autores Españoles, CCIX: 191-177; Madrid: Ediciones Atlas.

ÁVILA, F. de., 1966[¿1598?] - Dioses y hombres de Huarochirí, 278p.; Lima: Museo Nacional de Historia - Instituto de Estudios Peruanos.

BARBA, F., 1997 - Frontera ganadera y guerra con el indio. La frontera ganadera en Buenos Aires entre los siglos XVIII y XIX, 155p.; La Plata: Editorial de la Universidad de La Plata.

BENSON, E. P., 1972 - The Mochica, a culture of Peru, 164p.; London: Thames and Hudson.

BERTONIO, L., 1879[1612] - Vocabulario de la lengua aymara compuesta por el padre..., 400p.; Leipzig: Julio Platzman.

BOMAN, E., 1908 - Antiquités de la région andine de la République Argentine, 948p.; 2 tomos; Paris: Imprimerie Nationale.

BOMAN, E., 1927-1932 - Estudios arqueológicos riojanos. Anales del Museo Nacional de Historia Natural "Bernardino Rivadavia”, XXXV, 341p.; Buenos Aires.

BOURGET, S., 1998 - Pratiques sacrificielles et funéraires au site Moche de la Huaca de la Luna, côte nord du Pérou. Bulletin de l'Institut Français d'Études Andines, 27(1): 41-74, Lima.

BOUYSSE-CASSAGNE, T. \& BOUYSSE, P., 1988 - Lluvias y cenizas. Dos Pachacuti en la Historia, 228p.; La Paz: Hisbol.

BRAVO, D., 1975 - Diccionario Quichua Santiagueño - Castellano, 194p.; Buenos Aires: Editorial Universitaria de Buenos Aires.

BREGANTE, O., 1926 - Ensayo de clasificación de la cerámica del Noroeste argentino, 321p. + 20 planchas; Buenos Aires: A. Estrada y Cia., Editores.

BRUCH, C., 1911 - Exploraciones arqueológicas en las provincias de Tucumán y Catamarca, 209p.; Buenos Aires: Coní Hermanos.

CÁCERES FREYRE, J. B., 1961 - Diccionario de Regionalismos de la Provincia de La Rioja, 203p.; Buenos Aires: Instituto Nacional de Investigaciones Folklóricas.

CÁCERES FREYRE, J. B., 1962 - Homenaje a Samuel A. Lafone Quevedo. Cuadernos del Instituto Nacional de Investigaciones Folklóricas, 3: 9-34; Buenos Aires.

CAÑETE Y DOMINGUEZ,P. V., 1952[1791]- Guía histórica, geográfica, física, política, civil y legal del Gobierno e Intendencia de la Provincia de Potosí, 838p.; Potosí: Editorial Potosí.

CARRIÓNCACHOT, R., 1955 - El culto al agua en el antiguo Perú - La Paccha elemento cultural Pan-andino. Revista del Museo Nacional de Antropología y Arqueología, II: 1-100. Lima.

CARRIÓN CACHOT DE GIRARD, R., 1959 - La religión en el antiguo Perú (norte y centro de la costa, período post-clásico), 150p.; Lima: edición del autor.

CARRIZO, J. A., 1942 - Cancionero popular de La Rioja, recogido y anotado por.... 3 tomos, 1154p.; Buenos Aires: A. Baiocco y Cía., Editores. Universidad Nacional de Tucumán.

CARRIZO, J. M. \& PERKINS HIDALGO, G., 1948 - Cuentos de la tradición oral argentina recogidos en Catamarca y Corrientes por .... Introducción y notas por Bruno C. Jacovella. Revista del Instituto Nacional de la Tradición, I: 51-114; Buenos Aires. 
CASTRO DE TRELLES, L., 1992 - Edición, estudio preliminar y notas de "Relación de la religión y ritos del Perú hecha por los padres agustinos": I-XCI; Lima: Fondo Editorial, Pontificia Universidad Católica del Perú.

CHERTUDI, S. \& NEWBERY, S. J., 1978 - La difunta Correa, 240p.; Buenos Aires: Editorial Huemul.

COBO, B., 1964[1653] - Historia del Nuevo Mundo. In: Biblioteca de Autores Españoles, XCII(II): 555p.; Madrid: Ediciones Atlas.

COLATARCI, M. A., 1994 - Aportes para el estudio de las celebraciones vigentes en la puna jujeña (República Argentina). Mitológicas, 9: 15-46; Buenos Aires: Centro Argentino de Etnología Americana.

COLUCCIO, F., 1981 - Diccionario Folklórico Argentino, 712p.; Buenos Aires: Editorial Plus Ultra.

COLUCCIO, F., 1995 - Las devociones populares argentinas, 239p.; Buenos Aires: Ediciones Nuevo Siglo.

COLUCCIO, F. \& COLUCCIO, M. I., 2000 - El diablo en la tradición oral de Iberoamérica, 315p.; Buenos Aires: Corregidor.

CONÍ, F. A., 1951[1877-1880] - Diccionario geográfico argentino, 512p., Buenos Aires: Imprenta Coní.

CUTOLO, V. O., 1968-1985 - Nuevo diccionario biográfico argentino, 7 tomos, 5053p.; Buenos Aires: Elche.

DEBENEDETTI, S., 1912 - Influencia de la cultura de Tiahuanaco en la región del Noroeste Argentino (nota preliminar). Revista de la Universidad de Buenos Aires, XVII: 326 y stes; Buenos Aires.

DEBENEDETTI, S., s/f[¿1913?] - Notas inéditas, en cinco carpetas con dibujos y fotos, parcialmente publicadas por Odilla Bregante, tomadas en el Museo Etnográfico de Berlín y existentes en el Archivo del Museo Etnográfico de la Facultad de Filosofía y Letras de la Universidad de Buenos Aires.

DEBENEDETTI, S., 1930 - Las ruinas del Pucará. Tilcara, quebrada de Humahuaca (provincia de Jujuy), 142p. + 26 láminas + 2 cartas y 29 figuras fuera de texto; Buenos Aires: Facultad de Filosofía y Letras, Universidad de Buenos Aires.

DEBENEDETTI, S., 1931 - L'ancienne civilisation des Barreales, 56p. + 68 láminas; Paris: Ars Americana.

DE LA VORÁGINE, S., 1987[c.1264] - La leyenda dorada, 2 tomos, 991p.; Madrid: Alianza Editorial.

DOUCET, G. G., 1976 - Las Ordenanzas de aguas para La Rioja del visitador Don Francisco de Alfaro (1611). Revista de Historia del Derecho, 4: 397-425; Buenos Aires.

DOUCET, G. G., 1980 - Notas sobre el yanaconazgo en el Tucumán. Anuario Histórico Jurídico Ecuatoriano, VI: 459-494; Quito.

DOUCET, G. G., 1983 -La administración de aguas en La Rioja bajo el régimen español: aportes para su estudio. Revista de Historia del Derecho, 11: 491-506; Buenos Aires.

DRAGOSKI, G. \& PÁEZ, J. - 1972 - Fiestas y ceremonias tradicionales, 117p.; Buenos Aires: Centro Editor de América Latina.

ENCUESTA AL MAGISTERIO, 1921 - Instituto Nacional de Antropología y Pensamiento Latinoamericano. Carpetas correspondientes a la provincias del área andina argentina.

ESCOBAR RISCO, G., 1951 - Prólogo y notas al: ANÓNIMO, 1951[1586] - Vocabulario y phrasis en la lengua general de los indios del Perú llamada quichua y en la lengua española: VII-XX; Lima: Universidad Nacional Mayor de San Marcos.

FERNANDEZ BACA COSIO, J., 1989 - Motivos de ornamentación de la cerámica Inca-Cuzco, 238p.; Lima: Studium.

FORGIONE, C. A., 1997 - El suri en el sistema de representaciones en la cultura andina del noroeste argentino. Scripta Ethnologica, XIX: 7-44; Buenos Aires: Centro Argentino de Etnología Americana. 
FORTUNY, P., 1974[1951] - Supersticiones calchaquíes (ensayo e interpretación), 299p.; Buenos Aires: Editorial Sofron.

FURLONG, G., 1936 - Cartografía Jesuítica, 2 volúmenes, 278p.; Buenos Aires: Instituto de Investigaciones Históricas.

GARCILASO DE LA VEGA, Inca, 1985[1609] - Comentarios Reales de los Incas, 2 tomos, 588p.; Caracas: Biblioteca Ayacucho.

GENTILE, M. E., 1974 - Uso ceremonial de cabezas humanas en Nasca. Antiquitas, XIX: 1-5; Buenos Aires: Universidad del Salvador.

GENTILE, M. E., 1986 - El "control vertical" en el noroeste argentino. Notas sobre los atacamas en el valle Calchaquí, 176p.; Buenos Aires: Casimiro Quirós, editor.

GENTILE, M. E., 1988 - Una escultura anatrópica de Catamarca. Antigal, 3: 14-15. Revisada y reeditada en Huacca Muchay...: capítulo 1.

GENTILE, M.E., 1991 - Correspondencias etnohistóricas entre dos estilos alfareros prehispánicos puneños. Comechingonia, número especial, 9: 217-252; Córdoba.

GENTILE, M. E., 1992 - Cuyo Suyo y Cuyo Marca. Revista de Estudios Regionales, 10: 69-108; Mendoza: Centro Interdisciplinario de Estudios Regionales. Universidad Nacional de Cuyo.

GENTILE, M. E., 1994 - Supervivencia colonial de una ceremonia prehispánica. Bulletin de l'Institut Français d'Études Andines, 23(1): 69-103; Lima. Reeditado en: Huacca Muchay..., 1999: capítulo 3.

GENTILE, M. E., 1995 - Rutuchicuy - La ceremonia incaica de imposición del nombre propio y su persistencia. Revista de Investigaciones Folkóricas, 10: 33-42; Buenos Aires. Revisado y reeditado en Huacca Muchay, 1999: capítulo 4.

GENTILE, M. E., 1996a - Tocpos - Historia colonial de un grupo diaguita en el siglo XVII. Cuadernos de Historia Latinoamericana, 3: 111-143; Münster.

GENTILE, M. E., 1996b - Dimensión sociopolítica y religiosa de la capacocha del cerro Aconcagua. Bulletin de l'Institut Français d'Études Andines, 25(1): 43-90; Lima. Reeditado en Huacca Muchay..., 1999: capítulo 2.

GENTILE, M. E., 1997 - Entre el derecho andino y el derecho español: la sucesión en el cacicazgo de los indios quilme reducidos en Buenos Aires. Revista de Historia del Derecho, 25: 305-364; Buenos Aires: Instituto de Investigaciones de Historia del Derecho.

GENTILE, M. E., 1998a - Rimani, quellcani, yuyani, Notas sobre las formas de registro, conservación y uso de datos durante el Tahuantinsuyu. Sequilao, 12: 43-63; Lima.

GENTILE, M. E., 1998b - La pichca: oráculo y juego de fortuna (su persistencia en el espacio y tiempo andinos). Bulletin de l'Institut Français d'Études Andines, 27(1): 75-131. Reeditado en Huacca Muchay...: capítulo 6.

GENTILE, M. E., 1998c - El cacicazgo prehispánico de Marapa según unos testamentos coloniales (Tucumán, siglos XVI-XVII). Ponencia leída en las XVIII Jornadas de Historia del Derecho Argentino. Instituto de Investigaciones de Historia del Derecho y Universidad Católica de Cuyo, San Luis, ms.

GENTILE, M. E., 1999a - El Familiar: etnohistoria de esta creencia. In: Huacca Muchay...: 195253, capítulo 5.

GENTILE, M. E., 1999b - Actualidad de las huacas andinas en la puna de Jujuy. In: Huacca Muchay...: 347-354, capítulo 8.

GENTILE, M. E., 1999c - Huacca Muchay - Religión Indígena. Religión, creencias, juegos. Área andina argentina, prehispánica, colonial, actual, 436p.; Buenos Aires: Instituto Nacional Superior del Profesorado de Folklore.

GONÇALEZ HOLGUÍN, D., 1952[1608] - Vocabulario de la lengua general de todo el Perú llamada lengua qquichua o del inca, 373p.; Lima: Instituto de Etnología, Universidad Nacional Mayor de San Marcos. 
GONZÁLEZ, A. R., 1975 - Pre-Columbian metallurgy of northwest Argentina: historical development and cultural process. In: Dumbarton Oaks Conference on Pre-Columbian Metallurgy of South America: 133-202; Washington.

GONZALEZ, A. R., 1977 - Arte precolombino de la Argentina - Introducción a su historia cultural, 470p.; Buenos Aires: Filmediciones Valero.

GONZALEZ, A. R., 1992 - Las placas metálicas de los Andes del Sur - Contribución al estudio de las religiones precolombinas, 311p. + 61 figs.; Mainz: Verlag Philipp von Zabern.

GONZÁLEZ, A. R. \& MONTES, A.E., 1998 - Cultura La Aguada. Arqueología y diseños, 336p. + 30 láminas; Buenos Aires: Filmediciones Valero.

GONZÁLEZ, A. R., \& NÚÑEZ REGUEIRO, V. A., 1968-1969 - Ensayo sobre los tensores y manoplas del noroeste argentino. Boletín del Museo Nacional de Historia Natural, XXX: 237-290; Santiago de Chile.

GRANADA,D., 1959[1896]-Reseña histórico-descriptiva de antiguas ymodernas supersticiones del Rio de la Plata, 438p.; Buenos Aires: Editorial Guillermo Kraft Limitada.

GUAMAN POMA DE AYALA, F.,1980[1613] - El Primer Nueva Coronica y Buen Gobierno, 3 tomos, 1175p.; México: Siglo XXI, Edición Crítica de R. Adorno y J.V. Murra.

GUARDIA MAYORGA, C. A., 1973 - Gramática kechwa, 388p.; Lima: Ediciones Los Andes.

GUY, D. J., 1981 - Política azucarera argentina: Tucumán y la generación del 80, 164p.; Tucumán: Ediciones Fundación Banco Comercial del Norte.

HUERTAS VALLEJOS, L., 1993 - Anomalías cíclicas de la naturaleza y su impacto en la sociedad: “el fenómeno El Niño". Bulletin de l'Institut Français d'Études Andines, 22 (1): 345-393; Lima.

HYSLOP, J., \& SCHOBINGER, J., 1990 - Establecimiento incaico en los nevados de Aconquija (Provincia Tucumán, Argentina). Gaceta Arqueológica Andina, V: 67-75; Lima.

IMBELLONI, J., 1940 - Síntesis antropológica. In: Los aborígenes de Santiago del Estero: 78115; Buenos Aires: Relaciones de la Sociedad Argentina de Antropología II.

ITIER, C., 1993 - Estudio y comentario lingüístico. In: PACHACUTI YAMQUI SALCAMAYGUA, Joan de Santa Cruz, Relación de antiguedades deste reyno del Piru: 127-172; Lima-Cusco: Instituto Francés de Estudios Andinos y Centro de Estudios Regionales Andinos "Bartolomé de Las Casas". Edición facsimilar y transcripción paleográfica del Códice de Madrid.

JAIMES FREYRE, R., 1915 - El Tucumán Colonial (Documentos y mapas del Archivo de Indias), Volúmen I, 175p.; Buenos Aires: Imprenta y Casa Editora Coní Hermanos.

KARSTEN, R., 1972 - La civilisation de l'Empire Inca. Un état totalitaire du passé, 272p.; Paris: Payot.

LAFONE QUEVEDO, S. A., 1888 - Londres y Catamarca. Cartas a "La Nación”, 1883-1885, 408p., con apéndices y un mapa histórico; Buenos Aires: Imprenta y Librería de Mayo.

LAFONE QUEVEDO, S. A., 1950[1892] - Ensayo mitológico. El culto a Tonapa. Los himnos sagrados de los reyes del Cuzco según en yamqui Pachacuti. In: Tres relaciones de antigüedades peruanas: 287-353; Asunción: Editorial Guarania.

LAFONE QUEVEDO, S. A., 1898 - Tesoro de Catamarqueñismos con etimologías de nombres de lugar y de persona en la antigua Provincia de Tucumán, 349p.; Buenos Aires: Imprenta Coní.

LARROUY, A., \& SORIA, M., 1921 - Autonomía catamarqueña, 242p.; Buenos Aires: Jacobo Peuser.

LARROUY, A., 1923 - Documentos del Archivo de Indias para la historia del Tucumán, Tomo Primero, 1591-1700, 432p.; Buenos Aires: L. J. Rosso \& Cía, Impresores.

LAURENCICH-MINELLI, L., MICCINELLI, C. \& ANIMATO, C., 1998 - Lettera di Francisco de Chaves alla Sacra Cesarea Cattolica Maestà: un inedito del sec.XVI. Studi e materiali di storia delle religioni, XXII, 1: 59-91; Roma: Università di Roma "La Sapienza". 
LAURENCICH MINELLI, L., 1999 - La "culpa" del cronista peruano P. Blas Valera. Anales del Museo de América, 7: 95-109; España: Ministerio de Educación y Cultura.

LEVILLIER, R., 1920a - Gobernación del Tucumán; papeles de gobernadores en el siglo XVI, 2 tomos, 1002p.; Madrid; Imprenta J. Pueyo. Documentos del Archivo de Indias.

LEVILLIER, R., 1920b - El Tucumán: probanzas de méritos y servicios de sus conquistadores, 1224p., 2 tomos; Madrid: Sucesores de Rivadeneira.

LEVILLIER, R., 1928 - Nueva Crónica de la conquista del Tucumán, 3 tomos, 1068p.; Lima Varsovia.

LEVILLIER, R., 1935-1942 - Don Francisco de Toledo, supremo organizador del Perú. Su vida, su obra (1515-1582) (3 tomos), tomo II: 122-177; Buenos Aires: Ediciones del Congreso de la Nación.

LIZONDO BORDA, M. (compilador), 1936-1949 - Documentos Coloniales relativos a San Miguel de Tucumán y a la Gobernación de Tucumán, 6 volúmenes, 1805p.; Tucumán : Junta Conservadora del Archivo Histórico de Tucumán.

LOZANO, Pedro, 1874-1875[1745] - Historia de la conquista del Paraguay, Rio de la Plata y Tucumán, 5 tomos, 2287p.; Buenos Aires: Imprenta Popular.

LOZANO, P., 1970[1754] - Historia de la Compañía de Jesús en la provincia del Paraguay, 2 tomos, 1599p.; Westmead: Gregg International.

LUMBRERAS, L. G., 1978 - El arte y la vida Vicús, 180p.; Lima: Colección del Banco Popular del Perú.

MABRES, A., WOODMAN, R. \& ZETA, R., 1993 - Algunos apuntes históricos adicionales sobre la cronología de El Niño. Bulletin de l'Institut Français d'Études Andines, 22(1): 395-406; Lima.

MARTÍN, E. H., 1963 - Apellidos indígenas documentados en los archivos provinciales del noroeste argentino, 93p.; Buenos Aires: Facultad de Filosofía y Letras, Universidad de Buenos Aires. Cuadernos de Lingüística Indígena 1.

MARTIN DE MOUSSY, V., 1860-Description géographique et statistique de la Confédération Argentine, 3 volúmenes; Paris: Librairie de Firmin Didot Frères, Fils et Cie.

MATIENZO, Juan de, 1967 [1567]-Gobierno del Perú. Instituto Francés de Estudios Andinos, 366p; Lima.

MAYO, C. \& LATRUBESSE, A., 1993 - Terratenientes, soldados y cautivos: la frontera (1736 - 1815), 137p.; Universidad Nacional de Mar del Plata, Colegio Nacional Dr. Arturo U. Illia, Grupo Estado y Sociedad. Imprenta de la Universidad.

MICHIELI, C. T., 2000-La disolución de la categoría jurídica-social de "indio" en el siglo XVIII: el caso de San Juan (región de Cuyo), 135p.; Instituto de Investigaciones Arqueológicas y Museo, Universidad Nacional de San Juan, Publicaciones 23 (nueva serie).

MOLINA, C. de, "del Cuzco", 1916[1575] - Relación de las fábulas y ritos de los incas, 215p.; Lima: Imprenta y Librería Sanmartí \& Cía. Colección de Libros y Documentos referentes a la Historia del Perú.

MONTES, A., 1950 - Nomenclador cordobense de toponimia autóctona. Anales de Arqueología y Etnología, XI: 33-80, y XII: 75-113; Mendoza: Universidad Nacional de Cuyo.

MONTESINOS, F. de, 1957[1644] - Memorias Antiguas Historiales y Políticas del Perú. Edición de L. A. Pardo y C. A. Galimberti Miranda. Revista del Museo e Instituto de Arqueología, 16-17: X+114p.; Cusco.

MORENO, J. L., 1989 - Población y sociedad en el Buenos Aires rural a mediados del siglo XVIII. Desarrollo Económico, 29(11): 265-282; Buenos Aires.

MORENO, J. L., 1998 - Sexo, matrimonio y familia: la ilegitimidad en la frontera pampeana del Río de la Plata, 1780-1850. Boletín del Instituto de Historia Argentina y Americana, 1617: 61-84; Buenos Aires.

MURRA, J. V. (editor), 1991 - Visita de los valles de Sonqo en los yunka de coca de La Paz(15681570), 687p.; Madrid: Instituto de Cooperación Iberoamericana e Instituto de Estudios Fiscales. 
MURÚA, M. de, 1946[1590] - Historia del origen y genealogía real de los Reyes Incas del Perú, 443p.; Madrid: Ediciones Verdad. Introducción, notas y arreglo de Constantino Bayle S.J.

MURUA, M., 1986[1613] - Historia General del Perú, 584 p.; Madrid: Historia 16.

NAROSKY, T. \& YZURIETA, D., 1993 - Guía para la identificación de las aves de Argentina y Uruguay, 346p.; Buenos Aires: Sociedad Ornitológica del Plata (Cuarta Edición).

NÚÑEZ REGUEIRO, V., 1971 - La cultura Alamito de la subárea valliserrana del noroeste argentino. Journal de la Société des Américanistes, LX: 7-66; Paris.

PACHACUTIYAMQUISALCAMAYGUA, J.de Santa Cruz, 1993-Relación de antiguedades deste reyno del Piru, 276p.; Lima-Cusco: Instituto Francés de Estudios Andinos y Centro de Estudios Regionales Andinos "Bartolomé de Las Casas". Estudio etnohistórico y lingüístico de Pierre Duviols y César Itier. Edición facsimilar y transcripción paleográfica del Códice de Madrid.

PEASE G.Y., F., 1995 - Las Crónicas y Los Andes... 632p.; Lima: Pontificia Universidad Católica del Perú, Instituto Riva Agüero, Fondo de Cultura Económica.

POLO DE ONDEGARDO, J., 1917[1571] - Relación de los adoratorios de los indios en los cuatro caminos que salian del Cuzco. In: Informaciones acerca de la Religión y Gobierno de los incas: 3-43; Lima: Imprenta y librería Sanmarti \& Cia. Notas biográficas y concordancias de los textos por Horacio H.Urteaga.

POSNANSKY, A., 1957 - Tihuanacu. La cuna del hombre americano, tomos III y IV; La Paz: Ministerio de Educación.

PULGAR VIDAL, J., 1976 - Quilcas, arte rupestre del Perú, 12p.; Lima: Catálogo de la Galería del Banco Continental.

QUINN, W. H., 1993 - The large-scale ENSO event, the El Niño and other important regional features. Bulletin de l'Institut Français d'Études Andines, 22(1): 13-34; Lima.

QUINTANILLA, R. H, RIZZO, H. F. \& FRAGA, C. P., 1980[1973] - Roedores perjudiciales para el agro en la República Argentina, 112p.; Buenos Aires: Editorial Universitaria de Buenos Aires.

QUIROGA, A., 1897 -Folk-lore calchaquí. Boletín del Instituto Geográfico Argentino, 18: 548574; Buenos Aires.

QUIROGA, A., 1977[1901] - La cruz en América, 193p.; San Antonio de Padua: Ediciones Castañeda.

QUIROGA, C. , [s/d] - Cerro Nativo (citado por J.Z.Agüero Vera).

RAFFINO, R. A. et al., 1979-1982 - La expansión septentrional de la cultura La Aguada en el NOA. Cuadernos del Instituto Nacional de Antropología, 9: 7-35; Buenos Aires.

RAFFINO, R. A., 1991 - Poblaciones indígenas en Argentina - Urbanismo y proceso social precolombino, 272p.; Buenos Aires: Tipográfica Editora Argentina (2da.edición).

RAFFINO, R. A., IÁCONA, A. \& GARCÍA MONTES, V., 1997-Los “suplicantes” del Museo de La Plata, 46p. + XIII láminas; Buenos Aires: Union Académique Internationale Academia Nacional de la Historia.

RAMOS GAVILÁN, A., 1976[1621] - Historia de Nuestra Señora de Copacabana, 257p.; La Paz: Academia Boliviana de la Historia. Segunda edición completada, según la impresión príncipe de 1621.

RAMOS, J. P. \& CÓRDOBA, P. A., 1921 - Instrucciones a los maestros para el mejor cumplimiento de la resolución adoptada por el Honorable Consejo sobre Folklore Argentino. Monitor de la Educación Común, 580: 3-25; Buenos Aires.

RAVIGNANI, E., 1932 - La población indígena de las regiones del Río de la Plata y Tucumán en la segunda mitad del siglo XVII. In: Actas del XXV Congreso Internacional de Americanistas, II: 295-305; La Plata, Buenos Aires.

ROSENZVAIG, E. \& BONANO, L. M., 1992 - De la manufactura a la revolución industrial. El azúcar en el norte argentino: fases y virajes tecnológicos, 186p.; Tucumán: Universidad Nacional de Tucumán. 
ROSSO, A. D., 1975 - Arte milenario indoamericano. Exposición arqueológica, 28p.; Buenos Aires: Biblioteca del Congreso de la Nación y Museo Nacional de Arte Decorativo.

ROWE, J. H., 1979 - An account of the shrines of ancient Cuzco. Nawpa Pacha, 17: 1-80; Berkeley.

SAIGNES, T. (compilador), 1993 - Borrachera y memoria. La experiencia de lo sagrado en los Andes, 202p.; La Paz: HISBOL - Instituto Francés de Estudios Andinos.

SANTO TOMAS, D. de, 1951[1560] - Lexicon o vocabulario de la lengua general del Perú, 374p.; Lima: Instituto de Historia de la Facultad de Letras - Universidad Nacional Mayor de San Marcos.

SARMIENTO DE GAMBOA, P., 1943[1572] - Historia de los Incas (2da.parte de la Historia General llamada Indica), 302p.; Buenos Aires: Emecé.

SCHMIDEL, Ulrich s/f[1554] - Mahrhastige historie einer wunderbaren schissahrt, welche Ulirch Schmidel, von Straubing von 1534 bis 1554 in America oder Neuewelt bei Brasilia oder Rio della Plata getan, 173p.+2 mapas; München: Albert Langen.

SEMPÉ, M. C., 1977a - Caracterización de la cultura Saujil. Obra del Centenario del Museo de La Plata, II: 211-235; La Plata.

SEMPÉ, M. C., 1977b - Las culturas agroalfareras prehispánicas del valle de Abaucán (Tinogasta-Catamarca). Relaciones de la Sociedad Argentina de Antropología, n.s., XI: 55-68; Buenos Aires.

SOLDI, A. M., 1980 - El agua en el pensamiento andino. Boletín de Lima, 6: 21-27; Lima.

SOLDI, A. M., 1997 - Un inédito de Toribio Mejía Xesspe: "Los keros de Chillwa 1925". In: Homenaje a María Rostworowski: 77-91; Lima: Instituto de Estudios Peruanos.

TARTUSI, M. R.A. \& NÚÑEZ REGUEIRO, V. A., 1993 - Excavación de un montículo ceremonial tardío en el sitio STucTav 5(El Pichao), Provincia de Tucumán. Publicaciones, 2: 1-17; San Miguel de Tucumán: Instituto de Arqueología, Universidad Nacional de Tucumán.

TAYLOR, G., 1987 - Ritos y Tradiciones de Huarochirí del siglo XVII, 616p.; Lima: Instituto de Estudios Peruanos - Instituto Francés de Estudios Andinos.

TELLO, J.C., 1931 - Un modelo de escenografía plástica en el arte antiguo peruano. Wira Kocha, 1(1): 87-112; Lima.

TELLO, J. C., 1938 - Arte antiguo peruano - Album fotográfico de las principales especies arqueológicas de Cerámica Muchik existentes en los Museos de Lima. Primera parte: Tecnología y morfología. Revista Inca, II, 280p.; Lima.

TELLO, J. C. y MEJÍA XESSPE, T., 1979 - Paracas II ${ }^{a}$ parte - Cavernas y Necrópolis, 503p.; Lima: Universidad Nacional Mayor de San Marcos.

THE TEXTILE ART OF PERU, 1991 - 370p.; Lima: Textil Piura.

THOMPSON, L. G., 1993 - Reconstructing the paleo ENSO records from tropical and subtropical ice cores. Bulletin de l'Institut Français d'Études Andines, 22(1): 65-83.

TOMOEDA, H., 1994 - Los ritos contemporáneos de camélidos y la ceremonia de la citua. In: El mundo ceremonial andino, Luis Millones y Yoshio Onuki (compiladores): 283-299; Lima: Editorial Horizonte.

TORRES RUBIO, D. de, 1945 [1619] - Vocabulario segundo del castellano al indico por el padre... Aumentado después con los vocablos de la lengua Chinchaisuyo, por el padre Juan de Figueredo. Reedición dirigida por el Dr. Luis A. Pardo. Revista Universitaria, 8889:113-166; Universidad Nacional del Cuzco. Perú.

TORRE REVELLO, J., 1941 - Documentos históricos y geográficos relativos a la conquista y colonización rioplatense; 4 tomos, 2438p.; Buenos Aires: Jacobo Peuser.

VALCÁRCEL, Luis E., 1952 - El calendario andino. Gaceta Campesina, I: 20-26; La Paz: Ministerio de Asuntos Campesinos. 
VIGNATI, M. A., 1953 - Antigüedad histórica de los entierros de párvulos en el noroeste argentino. Notas del Museo de la ciudad Eva Perón, tomo XVI. Antropología, No 62: 151155; Universidad Nacional de la ciudad Eva Perón, Facultad de Ciencias Naturales y Museo.

WASSÉN, S. H., 1972 - A medicine-man's implements and plants in a Tiahuanacoid tomb in highland Bolivia, 196p.; Etnologiska Studier 32, Göteborgs Etnografiska Museum. Sweden.

\section{Apéndices documentales (1)}

1. "Canto del Chiqui” según Samuel A. Lafone Quevedo, con sus comentarios y traducción.

"Canto del Chiqui

Huairapuca Corriti;

Runaca cusiqui cusiqui purinqui:

Caballumpi armachis armachis purinqui:

Arquituta silvas silvas purinqui:

Huilla, talca, saltas saltas purinqui:

Uñapa, uñapa cuasi pasa:

Uñapa, uñapa, asilo topanse asilo guatanse;

¡Huipe, Huipe!

¡Cot, Cot, Cot!

Esto cantaban, en seguida daban aloja al Cacique y se repetía todo al cansancio. Como se ve la cancion esta parece ser una jerga de Quichua, Español y quien sabe qué mas. Ella fué trascrita como le sonaba al amigo que me favoreció con ella, y la traduccion no se da, porque falta que esclarecer muchas dudas. Los que viven en los lugares donde aun se canta el Chiqui, como por ejemplo en Pituil de la Rioja, acaso consigan una edicion mas correcta, que por lo menos se ajuste mas al mecanismo gramatical.

Huairapuca es el Zonda Colorado que trae el polvillo.

Corriti puede derivarse de la radical Cori, oro.

Huilla es, liebre.

Talca es, huanaco.

Uñapa es, india muy vieja.

Muchas de las palabras que suenan al idioma nuestro pueden no responder mas que á una analogía fonética casual, -debida á una separacion equivocada de sílabas-Topa y Huata son palabras solares, y aun Salta puede serlo-Mientras no se haga la luz en medio de tanta confusion he preferido abstenerme de dar traduccion alguna-. Lo mas probable es que tenemos un trozo de algun himno solar." (Lafone Quevedo, 1888: 377-380).

2. “Chiqui. Canto del Chiqui. Especie de vidala que se cantaba ó entonaba en las fiestas. En 1886 el Presbítero Juan Vásquez y Amado, Cura de San Blas de los Sauces,

(1) Todos estos textos se transcribieron según las normas internacionales propuestas durante la Primera Reunión Interamericana de Archivos, Washington, 1961. 
hizo apuntar la letra de este canto que es como sigue: [aquí se repite el mismo texto del apéndice anterior].

El texto, como se ve, es un salpicón de Castellano y Quichua, pero parece que puede traducirse así, á pesar de que algunas de las voces no responden á ninguna de las dos lenguas en su forma.

version aproximada

O viento colorado (2) corre.

Tú el indio andas alegre, alegre (3),

A caballo haciendo, haciendo que bañe (4) andas

Toda la noche (5) silbando, silbando (6) andas;

Liebre, Guanaco, saltando, saltando (6), andas;

O India Vieja, India Vieja (7), casi pasa,

O India Vieja, India Vieja,

Asi dizque lo topan, dizque lo asan;

¡Huipe, Huipe! (8)

¡Cot, Cot, Cot! (8)

3. “El padre Jorge A. Lira traduce guairapuca no como viento colorado, pues que para ser así debiera anteponer a guaira (viento) el adjetivo puca (colorado), lo que da pucaguaira; guairapuca es para el padre Lira: tierra colorada llevada por el viento.

La traducción del padre Lira [del canto del chiqui] sería:

Tierra, llevada por el viento, ¡corre, corre!

Pues que las gentes, alegres, alegres, andan

Bañados (en sudor), a caballo,

En noches tenebrosas andarán silbando

Dando vueltas como liebre como talca (¿guanaco?)

¡Cuán contentas andan las crías!

¡Las crías, las crías!

Así se los topa, así se los ata

Huipe, huipe

¡cot, cot, cot!” (Carrizo, 1942: 434).

(2) Ver Huairapuca. [esta entrada no está en su “Tesoro...”].

(3) Mejor Ccuzqui, tierras sedientas de riego, ardidas, quemadas por el sol y por la seca.

(4) Construcción muy Diaguita: imata mascas purinqui. ¿Qué andas buscando?

(5) Arquituta, no es voz Quichua y se ignora lo que el prefijo Arqui pueda significar.

(6) A todas luces estas son voces castellanas. La fonología del Cuzco rechaza estas combinaciones.

(7) Uñapa es voz local que dice India Vieja, uña en Quichua es cordero, y Uñay, tiempo antiguo.

(8) Imitaciones del grito de las "Aves del Campo".

A la vieja que yo le oí cantar sólo le pude apuntar el estribillo Selensé, murmurado en monótono y voz tembleque." (Lafone Quevedo, 1898: 103-104). 
4. Encuesta al Magisterio, 1921

[Versión No 1 ]

Provincia de Córdoba, Legajo 107; Localidad: Pozo del Molle, Escuela Nº 1. [No figura el nombre de la persona entrevistada].

[f.7v] "Fiesta o juego del Chiqui. Existe aun en el pequeño pueblito de Antinaco, situado en Serranias del Velazco, Departamento Famatina, un corpulento y añoso algarrobo - que le llaman del "Chiqui" porque según cuentan los vecinos, allí celebraban dicha fiesta; era el paraje destinado a los festejos populares, donde hacían las ceremonias con animales de caza: guanacos, liebres, quirquinchos, perdices etc. menos avestruces.

Danzaban alrededor del arbol, entonando cánticos y vidalitas, acompañados con tambores.

Ahí se servian la aloja, efectuando después carreras de a pié, hombres y mujeres; recibiendo el primero que llegaba premios que consistían en quesillos (pasta hecha de leche) [,] amasados hechos de harina de algarroba (9), etc.

Este arbol se halla cercado y cubierto de vid. Hasta no hace mucho tiempo, debajo de ese árbol, se hacían los festejos de carnaval, sirviendo también para punto de reunion de los principales pobladores, cuando tienen que deliberar asuntos de la comunidad."

\section{[Versión $\mathbf{N}^{\circ}$ 2]}

Gobernación de Los Andes (Legajo 3) (Mención); Localidad: Susques, Escuela $\mathrm{N}^{\mathrm{o}}$ 3. [No figura el nombre de la persona entrevistada].

[f.1r] "Canto del Chiqui" (traducción) (10)

Esta traducción la hacemos por cada palabra separada

Huaira puca corriti

Runaca cusiqui cusiqui purinqui

Caballumpi armachis

Armachis purinqui

Arquituta silvas

Silvas purinqui

Huilla talca saltas

[f.1v]

saltas purinqui

uñapa unapa [sic] cuasipasa
Viento colorado corre o sopla

Gente alegre alegre camina

En caballo armado

Armado camina

Antinoche silvando

Silvando camina

Avisame donde saltando

saltando camina

galopa galopa casi me pasa

(9) Se refiere al patay, "especie de mazapán fabricado con harina de algarroba negra obtenida en la cimbra [mortero con balancín], luego bien cernida y finalmente soasada dentro de unos moldes o pucos." (Cáceres Freyre, 1961: 148). (nota MG).

(10) Del canto este no tienen noticia alguna los habitantes andinos y la traducción de talca y huipe solo encontré 2 personas que la supieran. El resto es de habla corriente." 
uñapa uñapa asi lo topanse asi lo guatanse

¡Huipe! ¡Huipe!

¡cot! ¡cot! ¡cot! galopa galopa asi lo encuentro asi lo ata (o atais)

Palabra que significa gritos

exclamativos de ¡ánimo!

Exclamación que se hace a los animales para que detengan su marcha.

\section{[Versión No 3]}

Provincia de La Rioja, Caja 4, Legajo 130, Escuela No 51; Localidad: Arauco. Narrador: señor Rosario Fuentes, 71 años.

[f.7r] "El chiqui se jugaba en la juventud de este señor, donde también el tomó parte alguna vez - pero en la forma igualmente descripta en el folleto de instrucciones al respecto."

\section{[Versión No 4]}

Provincia de La Rioja, Caja 5, Legajo 140, Escuela 118; Localidad: Lorohuasi

Narradora: Baldomera Diaz de Reyes, 84 años, otras personas también conocen el relato.

[f.1r] "Creencias y costumbres.

SchiQuí. Le llamaban á una carrera entre mujeres diapi [de a pie]. Pillaban una liebre y le cortaban la cabeza y á esa la adornaban con cintas de todos colores.

La hacian brincar corrian las dos mujeres llevando la cabezita hasta llegar a la raya.

Jugaban por plata y volvían á tértulia, ah [ahí] eran los bailes y cantos."

5. Un cuento con loros, de la provincia de Entre Ríos

En el litoral fluvial, además de la alfarería que los representaba ampliamente, encontramos un relato sobre la solución ingeniosa que halló un agricultor para alejar de su chacra la amenaza de una bandada, y destacando la cualidad de estas aves de volar muy recio y muy alto, como decía Garcilaso, para burlarse de él.

"La fuerza de los loros

En tiempos antepasados, cuando por estos mundos los loros abundaban al extremo de ser una plaga para los plantíos de maíz, un señor de la selva de Montiel, cansado de los perjuicios y protestando de dicha plaga, todo desesperado y confuso, ideó trampas para ellos.

Madurado que fue su proyecto, procedió a colocar trampas de cimbra (trampa hecha de cerda en forma de armada) en cada uno de los gajitos de un algarrobo que se encontraba en medio de la chacra; hecho lo cual, procedió a espantar a los loros que a miles se encontraban por las plantas de maíz. 
Asustados, los loros volaron y se asentaron en el referido árbol, allí se pusieron a saltar de un lado a otro hasta que por último empezaron a trampearse. Fué entonces el señor muy contento, y con un largo látigo, de antemano gozoso por la acobardada que había de darles a los dichos ladrones, sacudió presuroso el árbol; pero cuál no fué su asombro cuando los animales, asustados por su presencia alzaron vuelo, llevándose consigo el árbol, que, arrancado de raíz, marchó con ellos, burlando de este [sic] suerte la ira del dueño, que estático y asombrado miraba la bandada de loros que llevaban en sus patas el corpulento instrumento de su obra.

Enviado por Crisanto Ovejero, Escuela $\mathrm{N}^{\circ}$ 86, Departamento Victoria (Entre Ríos).” (Carrizo \& Perkins Hidalgo, 1948: 90). 